(11) Nordic Council of Ministers

\title{
Ecosystem services in MSP
}

ECOSYSTEM SERVICES APPROACH AS A COMMON NORDIC UNDERSTANDING FOR MSP 



\section{Ecosystem services in MSP}

Ecosystem services approach as a common Nordic understanding for MSP

Mats Ivarsson, Kristin Magnussen, Anna-Stiina Heiskanen, Ståle Navrud and Markku Viitasalo

TemaNord 2017:536 


\section{Ecosystem services in MSP}

Ecosystem services approach as a common Nordic understanding for MSP

Mats Ivarsson, Kristin Magnussen, Anna-Stiina Heiskanen, Ståle Navrud and Markku Viitasalo

ISBN 978-92-893-5012-9 (PRINT)

ISBN 978-92-893-5013-6 (PDF)

ISBN 978-92-893-5014-3 (EPUB)

http://dx.doi.org/10.6027/TN2017-536

TemaNord 2017:536

ISSN 0.908-6692

Standard: PDF/UA-1

ISO 14289-1

(c) Nordic Council of Ministers 2017

Cover photo: Momenti.lv

Print: Rosendahls

Printed in Denmark

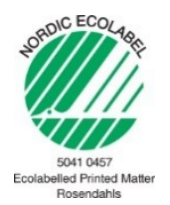

Although the Nordic Council of Ministers funded this publication, the contents do not necessarily reflect its views, policies or recommendations.

\section{Nordic co-operation}

Nordic co-operation is one of the world's most extensive forms of regional collaboration, involving Denmark, Finland, Iceland, Norway, Sweden, the Faroe Islands, Greenland, and Åland.

Nordic co-operation has firm traditions in politics, the economy, and culture. It plays an important role in European and international collaboration, and aims at creating a strong Nordic community in a strong Europe.

Nordic co-operation seeks to safeguard Nordic and regional interests and principles in the global community. Shared Nordic values help the region solidify its position as one of the world's most innovative and competitive. 


\section{Contents}

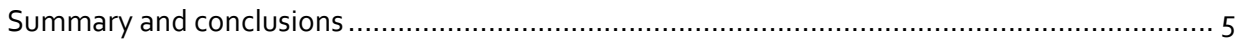

Marine spatial planning and ecosystem services...................................................... 5

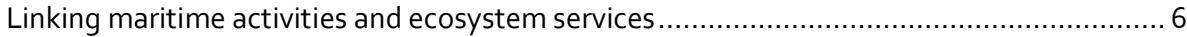

A practical tool for assessment of impact on ecosystem services from maritime activities ....7

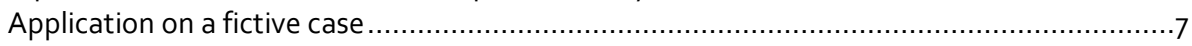

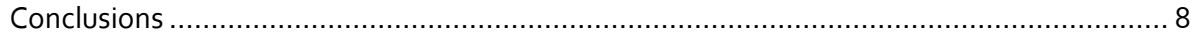

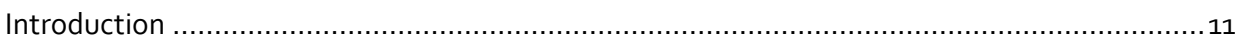

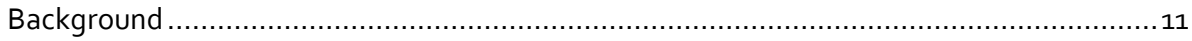

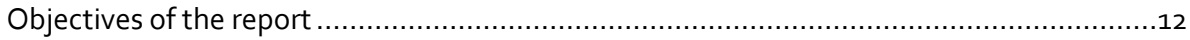

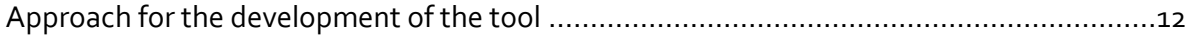

1. Development of a practical tool for assessing ecosystem services

in marine spatial planning

1.1 The role of maritime spatial planning in the management

of the marine environment.....

1.2 The role of ecosystem services in marine spatial planning .....................................18

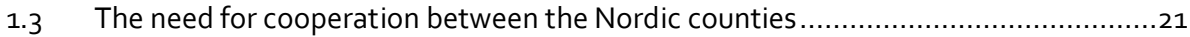

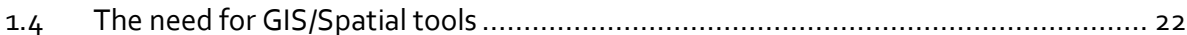

1.5 Marine Spatial Planning in the Nordic countries..................................................23

2. Linkages between maritime activities and ecosystem services ...................................... 25

$2.1 \quad$ Listing of marine ecosystem services and indicators ............................................ 26

2.2 Maritime sectors and associated environmental pressures ................................ 38

2.3 Connections between environmental pressures and marine ecosystem services ..... 43

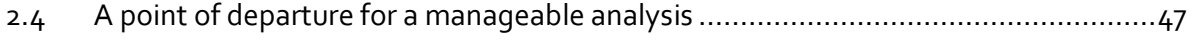

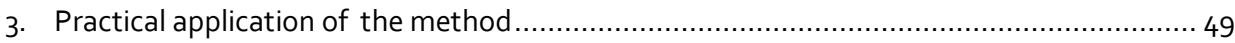

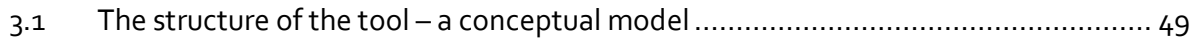

3.2 The need for active participation of stakeholder .............................................. 50

3.3 Some features of the analysis .................................................................. 51

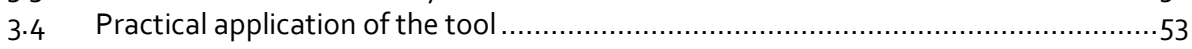

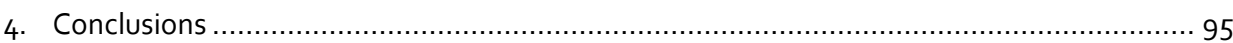

4.1 Potential for further development of the methodology ................................... 95

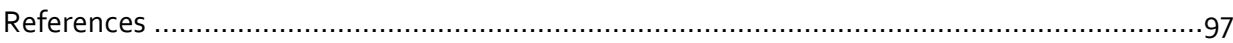

Svensk sammanfattning med slutsatser ............................................................... 103

Fysisk planering till havs och ekosystemtjänster................................................... 103

Kopplingen mellan marina aktiviteter och ekosystemtjänster .....................................105

Ett praktiskt verktyg för utvärdering av de maritima aktiviteternas påverkan på

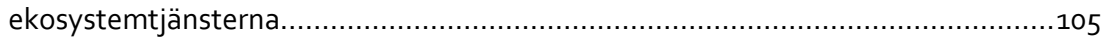

Tillämpning av metoden på ett fiktivt fallstudieområde ..........................................106

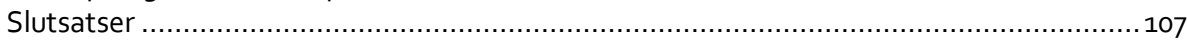


Appendix 1. CICES classification of marine ecosystem services

Appendix 2. Example of identification and selection of ecosystem services

classification for the Gulf of Finland (Baltic Sea).....

Appendix 3. Links between pressures and marine ecosystem services............................... 115

Appendix 4. Template for recording results from impact analysis ..................................... 118

Appendix 5. Template for compiling overall impact for each affected individual activity in a specific planning scenario

Appendix 6. Template for compiling overall impacts on ecosystem services from the relevant planning scenarios ............................................................... 123

Appendix 7. Marine spatial planning in the Nordic countries ......................................... 125

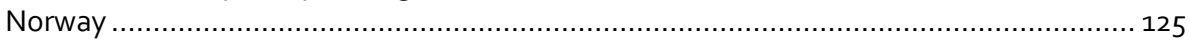

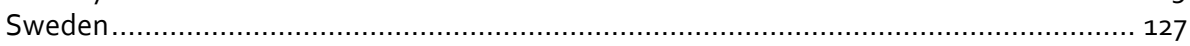

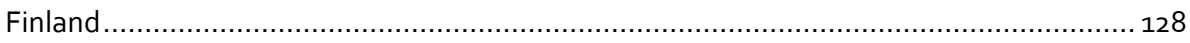

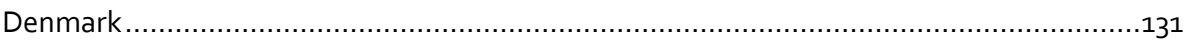

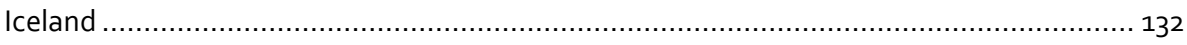

Marine Spatial Planning in the other Baltic Sea countries.......................................... 132

Appendix 8. Environmental pressures induce by individual marine/maritime sectors .............137

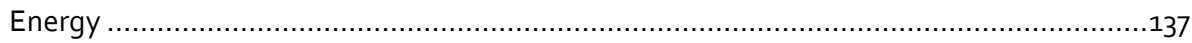

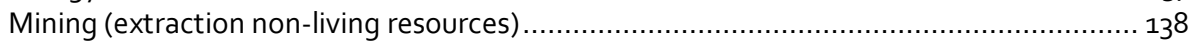

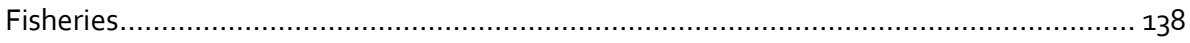

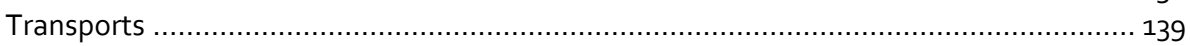

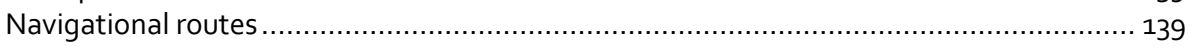

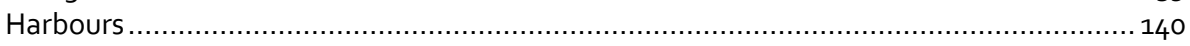

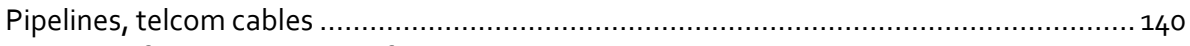

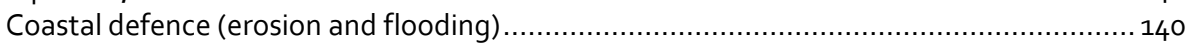

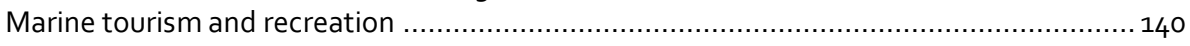

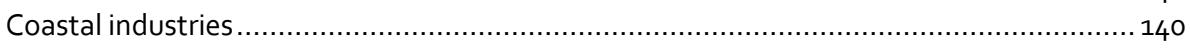

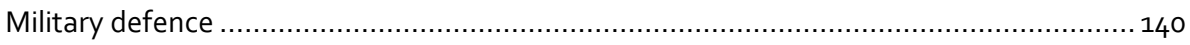

Appendix 9. Approach to assess impact on ecosystem services from

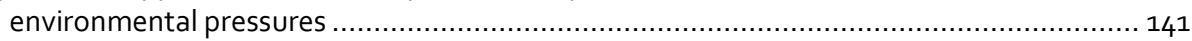

Three criteria for assessing environmental impact ............................................ 141

Overall impact score on ecosystem services ....................................................... 142

Appendix 10. Assessing the level of dependency on ecosystem services ............................ 145

Appendix 11. Marine ecosystem services valuation methods....................................... 147

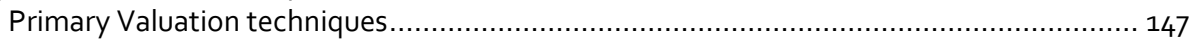

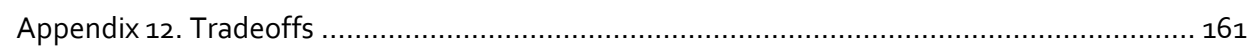

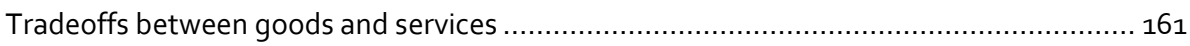

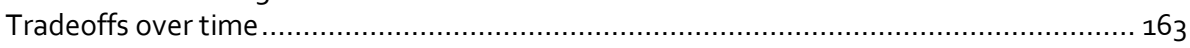

Tradeoffs between interest groups ................................................................. 163

Spatial tradeoffs and relationship between production and use of ecosystem services ..... 164

Appendix 13. The Convention on Biological Diversity (CBD) and MSP ............................. 165

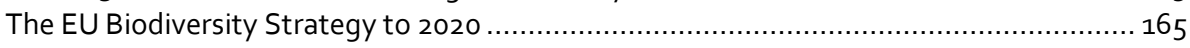

Links between the EU Biodiversity Strategy to 2020 (BDS2020) and MSP ......................166 


\section{Summary and conclusions}

The aim of this study is to describe and communicate a proposal for a new tool for assessing ecosystem services in marine spatial planning in the Nordic countries. The tool is based on a stepwise methodology on how to include ecosystem services assessment in maritime spatial planning processes by providing improved knowledge in all sustainability dimensions; ecological, economic and social desirability. This simple and transparent methodology is also intended to be used in the stakeholder participation, to raise awareness, to create understanding and acceptance, and to help reaching an agreement in the case of conflict regarding the use of marine space.

\section{Marine spatial planning and ecosystem services}

Maritime spatial planning (MSP) is intended to promote sustainable usage of the resources of the sea. By reconciling the potentially conflicting needs of different economic sectors, and by safeguarding the structure and functioning of the marine ecosystem, MSP also directly or indirectly supports the provision of ecosystem services provided by the sea.

The goal of the Maritime Spatial Planning Directive (MSPD) is to allocate the maritime activities in a way that they will not conflict with each other and with the marine ecosystem, and to allow sustainable utilization of marine resources and marine space protection of the marine ecosystem and its services. MSPD should apply an ecosystem-based approach (which is defined in the Marine Strategy Framework Directive, (2008/56/EC), MSFD) with the aim of ensuring that the collective pressure of all activities is kept within levels compatible with the achievement of good environmental status. Mapping of marine ecosystem services is a prerequisite for their consequent assessment, hence, for preparing environmentally and societally relevant plans for the use of marine resources, i.e. maritime spatial plans.

MSPD aims at providing a planning process in relation to the concrete choices of the EU member states about how to pursue the objectives of other sectoral policies in their marine areas. However, the concept of ecosystem services has not been fully taken into account in setting the goals and targets of either MSFD or MSPD. In contrast, the EU Biodiversity Strategy 2020 (BDS2020) calls for the implementation of a mapping 
and assessment of the state and value of marine ecosystem services (MAES). This is requested in order to evaluate the benefits of the protection and management of marine ecosystems and to halt the loss of biodiversity in EU member states (Maes et al. 2013). The MSPD requires the development of a planning process that supports the achievement of the targets and goals of both MSFD and BDS2020 (details regarding the relation between BDS2020 and MSP are found in Appendix 13).

The environmental state of the sea is largely influenced by transboundary pressures, and many problems need to be tackled in international cooperation, thus both the MSFD and MSPD emphasize the need for harmonization of assessment methods and spatial plans between the member states. For the Nordic countries, including Norway as a non-EU member, international cooperation is particularly relevant given the common challenges and shared marine areas. The Nordic marine areas, stretching from Arctic Barent's Sea north of Norway via the Northeast Atlantic to the Danish straits, to the Baltic Proper and the Bothnian Bay, demonstrate the gradient of different marine ecosystem types. Despite the many differences between the areas in terms of their ecosystem characteristics, the Nordic countries all share the same overarching challenges for maritime spatial planning. A common Nordic understanding of how ecosystem services can be used as a tool in MSP could be a starting point in meeting these challenges.

\section{Linking maritime activities and ecosystem services}

The process for establishing the connections between marine/maritime activities and marine ecosystem services is guided by a number of steps. The first entails the choice of a suitable typology of ecosystem services to which the activities should be linked. At present, there are a number of overarching classification systems, some with thematic specifications available. For the practical tool, we suggest a typology of marine ecosystem services stemming from TEEB (TEEB 2010a) and put forward by BöhnkeHenrichs et al. (2013), see section 3.1 below.

The second step concerns the identification and definition of the marine/maritime activities and sectors that might be included in the analysis. Again, a number of suggestions for classifications and division of the marine/maritime sectors have been suggested in different EU member states (Suris-Regueiro et al. 2013) to underpin the implementation of marine environmental policy, i.e. MSFD. For use in the practical tool, we suggest the classification put forward by the European commission in the revision of annex III to the MSFD. This step also includes the identification of environmental pressures associated with the activities in the sectors. The classification of 
environmental pressures used is based on technical background documents for the revision of annex III to the MSFD, see section 3.2.

In the third step, the environmental pressures identified and compiled in the second step are used to identify affected ecosystem services in the policy area, see section 3.3.

\section{A practical tool for assessment of impact on ecosystem services from maritime activities}

The three steps briefly described in the previous section lay the ground for assessing the impact on the provision and quality of ecosystem services that may result from different planning scenarios. By adopting a methodology focusing on selecting activities, pressures and ecosystem services exclusively relevant for the policy area, the scope of the analysis becomes narrowed down and manageable.

The application of the tool follows a series of steps covering the process from identification of the policy area to valuation of economic consequences. Commonly this will involve evaluations of economic impact from implementing opposing or alternative planning scenarios in a marine area, it could also be delimited to assessing e.g. the impact on a single sector.

The economic consequences are assessed by valuation of the resulting changes in the provision of the affected ecosystem services. The objective of the economic valuation is to describe changes in wellbeing, accruing to different stakeholder groups. When possible, this is done by means of monetized values of changes, e.g. changes in net income from fishing due to changes in the availability of fishing grounds. In other cases, changes in wellbeing may have to be described semi-quantitatively (with scores), quantitatively (hectares, tons etc.) or qualitatively (text). The assessment can partly be considered to be a cost benefit analysis (CBA) in the sense that it also includes issues, or criteria, outside a traditional CBA, e.g. job opportunities and distributional effects.

\section{Application on a fictive case}

A fictive case from the Baltic Sea consisting of a reference scenario and a planning scenario is used to illustrate the steps in the methodology. The two scenarios cover the shallow areas just south of Gotland; Hoburgs bank, North and South Middlebank. In the reference scenario, the area is traversed by shipping routes both in the north and the south part. The environmental pressures from shipping affect protected areas close by (N2000 and Important Bird Areas) as well as important spawning grounds for halibut. 
In the planning scenario, the northern shipping route is closed, the protected areas are extended and an area designated for renewable energy (windfarms) is created in the southern part of the area.

The reference and the planning scenario are used to illustrate how the methodology put forward in this study can be used to elaborate the causal chain from changes in maritime actives to changes in environmental pressure and consequently, impact on quality and provision of ecosystem services. The illustration is concluded by a discussion on possible approaches to economic valuation of changes in ecosystem services as well as ways to address distributional analysis and tradeoffs between opposing or alternative planning scenarios.

\section{Conclusions}

The study clearly shows that making use of the proposed methodology enables and facilitates the incorporation of and accounting for ecosystem services in the planning process. However, in order to further facilitate ecosystem services analysis in marine spatial planning, and other applied contexts, there is a need for further adaptation and development of the indicators used for evaluation of changes in the provision and quality of ecosystem services. Future studies need to focus on improving the alignment of indicators used to evaluate ecosystem services, and indicators applied in MSFD and BSAP (HELCOM). Optimally, the same indicators should be used to evaluate the impacts on Good Environmental Status (GES) from environmental pressures originating from maritime activities and ecosystem services at the same time.

During the course of the project, a number of specific areas with potential for improvement have been identified:

- The scores applied in the study for evaluation of impact on ecosystem services are not fully adapted to assess positive impacts. An example is the positive effects from enlargement of protected areas, or the establishment of corridors between separated protected areas. Positive effects from such changes can not be handled by the present scoring system, instead they are accounted for in the part of the methodology dealing with distributional effects of different planning scenarios.

- This study has taken a first step to include mapping and assessment of the dependency on ecosystem services of different sectors and activities. The purpose was to include a method for establishing links between the sectors /activities causing environmental impact and the resulting loss of benefits and wellbeing 
among other sectors or stakeholders. For resource reasons, it has not been possible to include this step in the methodology.

- The methodology presented in this study is illustrated by a fictive planning scenario. In order to facilitate further development, e.g. according to the bullets above, the methodology needs to be applied to a real world case study. In addition to the scoring, this would also offer the possibility to demonstrate how monetized economic valuation of positive and negative effects on ecosystem services from alternative planning scenarios can be applied, as well as analysis of distributional effects and tradeoffs between opposing or alternative planning scenarios. 



\section{Introduction}

\section{Background}

Many of the maritime activities depend on the natural capital, or natural assets, of the marine environment and the ecosystem services that can be derived from them. At the same time those activities cause pressures that impact marine ecosystems and may deteriorate their capacity to sustain structures (such as species and habitats) and functions (such as primary production or nutrient regulation) that underpin the flow of ecosystem services and their benefits for the society. While criteria and objectives for local, regional and national environmental legislation and administration might differ between the Nordic countries, the environmental concerns related to maritime activities are shared. Maritime spatial planning (MSP) incorporates considerations of those environmental concerns while aiming to ensure sustainable economic activities. Marine (or Maritime) Spatial Planning (MSP) is - according to UNESCO - "a public process of analyzing and allocating the spatial and temporal distribution of human activities in marine areas to achieve ecological, economic, and social objectives that usually have been specified through a political process" (http://www.unesco-iocmarinesp.be/marine_spatial_planning_msp). Therefore, assessment of ecosystem services in relation to scenarios for maritime spatial planning (MSP) has a potential to shape and foster a common understanding of ecosystem based management of sustainable maritime development in the Nordic countries.

This report describes a tool to incorporate an ecosystem services approach into the maritime spatial planning process. The proposed tool provides a prototype for a methodology to analyze linkages between maritime activities and ecosystem services, and to assess the status of marine ecosystem services as a part of the MSP process. The report addresses the Nordic co-operation needs, economic valuation of ecosystem services and tradeoffs between concurrent use of the marine areas and ecosystem services. These issues are closely related to the objectives of other marine policies related to sustainable use of marine resources, e.g. The Marine Strategy Framework directive (2008/56/EC), The Water Framework Directive (2000/60/EC) and The Birds (2009/147/EC) and Habitats Directive (92/43/EEC). In addition to the EU-directives, there are a number of cross sectorial policies and strategies with relevance for Marine Spatial Planning (MSP), e.g. the EU's Integrated Maritime Policy (IMP). The IMP 
requires a cross cutting approach to the management and governance of seas and coasts to strengthen sustainable economic and environmental development. Together with a strategy for advancing the growth in the maritime sector; BlueGrowth, and Sea basin strategies for the implementation; EUSBSR, MSP is one of the key instruments of the IMP. Another example is the EU Biodiversity Strategy to 2020 which also highlights the importance of ecosystem services as a tool to describe the social cost incurred to society if the loss of biodiversity is allowed to continue unchecked.

\section{Objectives of the report}

The overall aims of the current work are:

- To describe and communicate a proposal for a new tool for assessing ecosystem services in marine spatial planning.

- To propose how to make the ecosystem services approach operational in the maritime spatial planning in the Nordic countries.

- To propose a simple methodology on how to include ecosystem services assessment in maritime spatial planning process: A way forward for ranking (for selection or dismissal) of the planning scenarios by providing improved knowledge in all sustainability dimensions; ecological, economic and social desirability.

The proposed methodology is based on established and generalized links between maritime activities and their dependence of and impact on ecosystem services. The tool aims to provide a simple and transparent methodology that can also be used in the stakeholder participation, in order to raise awareness, create understanding and acceptance, and to help reaching an agreement in the case of conflict regarding the use of marine space.

\section{Approach for the development of the tool}

Linkages between maritime activities and ecosystem services are complicated as one activity may depend on several services. For example, ecosystem services sustaining fisheries and aquaculture are dependent on the availability of marine space and on structure and functioning of several habitats, such as spawning and nursery areas, 
genetic resources, and food web structure and water quality in general (e.g. oxygen availability). Likewise, many activities cause pressures on marine ecosystems and may cause damages on their capacity to provide such services. Therefore, the categorization of the maritime activities with respect to their dependence on various types of ecosystem services as well as their pressure-impact links is needed. An overall list and categorization of marine activities and the pressures generated by those has been produced by the European Commission (EU), the links were presented in a technical background document developed for the revision of the Annex III of the EU Marine Strategy Framework directive. ${ }^{1}$

The prototype for a new tool consists of a series of evaluation tables where the human activities are evaluated in terms of their impact on ecosystem services. These tables are aimed for practical application, but should at the same time be general enough to be applied in different spatial scales at local, sub-regional, national, and international level.

The approach and preliminary methodology were presented and discussed in a workshop at the Swedish Agency for Marine and Water Management (SwAM) in Gothenburg on 5th September 2016. Representatives from a number of stakeholder organizations in Sweden, Finland and Norway (i.e. central governmental agencies with responsibility for MSP, regional authorities and municipalities) were invited to participate. The workshop aimed at discussing and elaborating on dependencies between ecosystem services and activities and provides feedback for the categorization of activities, an external project reference group was formed from the participant group after the workshop.

There are a number of challenges and open questions concerning the application of the ecosystem services approach in the MSP that are beyond the scope of the current report. In the future, the prototype needs to be tested, validated, and revised in order to be operational for the practical MSP work. The report entails opportunities for further development and refinement of tools.

\footnotetext{
${ }^{1}$ Worksheets of the generic framework of activities, pressures and impacts relevant to the marine environment are found embedded in the documentation of the 14th meeting of the Working Group on Good Environmental Status (WG GES), agenda item 5 ;

https://circabc.europa.eu/faces/jsp/extension/wai/navigation/container.jsp?FormPrincipal:_idcl=FormPrincipal:_id1\&FormP rincipal_SUBMIT=1\&id=gb6d36a4-c95e-49af-8dea-

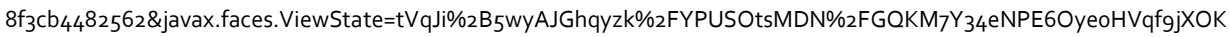
oTK1r2v\%2BhG8aYJ6BW4xW1jorOhc6\%2Bkkivr9gfrRLg29y5g1zoxxT6VjAVvEC\%2BKvyn5oFO3sbSeX88K6SZ8aAxLD6qH $\mathrm{NA}_{4}$ EqZLw9o\% ${ }_{3} \mathrm{D}$
} 



\section{Development of a practical tool for assessing ecosystem services in marine spatial planning}

Marine resources and ecosystem services are crucial for human well-being and development. All Nordic countries have long costal zones, and a large part of Nordic citizens live close to the sea and have a strong relationship with the coastal and marine areas (e.g. Ahtiainen et al. 2013). The Nordic marine areas are used for recreation, fisheries, energy production, infrastructure, industry production, and aquaculture. Many of these activities lead to pressures on the maintenance and production of ecosystem services. Allocating marine activities in these areas often implies competing interests which need to be balanced in maritime spatial planning (MSP), including the safeguarding of long term well-being through viable ecosystem processes, functions and services. An ecosystem services approach to MSP can provide a common understanding and underlying methodology in the Nordic countries for making the necessary tradeoffs within a safe operating space for the marine ecosystem. However, the tools for applying an ecosystem services approach in MSP in the Nordic countries are underdeveloped (e.g. Söderqvist et al. 2013).

The challenges of maintaining vital ecosystem functions in marine areas has entailed several international legislations and policies. In the Nordic countries both EU and national legislation, and agreements under the UN and IMO, ${ }^{2,3}$ OSPAR, ${ }^{4}$ and HELCOM conventions have to be taken into account when planning maritime activities. ${ }^{5}$ From 2014 maritime spatial planning is governed through the adoption of the EU Maritime Spatial Planning Directive (MSPD; Directive 2014/89/EU) which is currently in its initial implementation stage. All these marine policies request ecosystem based approach and assessment, in which ecosystem services are an important concept (e.g. EU Marine Strategy Framework Directive, MSFD - Directive

2 UNCLOS; United Nations Convention on the Law of the Sea. 3 MARPOL; International Convention for the Prevention of Pollution from Ships.

4 OSPAR; The Convention for the Protection of the Marine Environment in the North-East Atlantic - Oslo and Paris Convention. ${ }_{5}$ HELCOM; The Convention on the Protection of the Marine Environment in the Baltic Sea Area - the Helsinki Convention. 
2008/56/EC, and MSPD). An ecosystem-based approach requires a comprehensive integrated management of human activities based on the best available scientific knowledge about the ecosystem and its dynamics (HELCOM and OSPAR, 2003). Moreover, in the assessment of the coastal waters also EU Water Framework Directive (WFD; Directive 2000/60/EC) and Birds and Habitat Directives (BHD; Directives 2009/147/EC and 92/43/EEC) have to be considered as those include analysis of pressures and impacts and assessment of the ecological and favorable conservation status in the coastal and transitional waters.

The Maritime Spatial Planning Directive contributes to the effective management of marine activities and the sustainable use of marine and coastal resources, by creating a framework for consistent, transparent, sustainable, and evidence based decisionmaking. MSPD describes the obligations of the EU member states to establish a maritime planning process, resulting in maritime spatial plans.

MSPD aims at providing a planning process in relation to the concrete choices of the member states about how to pursue the objectives of other sectoral policies in their marine areas. However, the concept of ecosystem services has not been fully taken into account in setting the goals and targets of either MSFD or MSPD. In contrast, the EU Biodiversity Strategy 2020 (BDS2020) calls for the implementation of a mapping and assessment of the state and value of marine ecosystem services (MAES). This is requested in order to evaluate the benefits of the protection and management of marine ecosystems and to halt the loss of biodiversity in EU member states (Maes et al. 2013). The MSPD requires the development of a planning process that supports the achievement of the targets and goals of both MSFD and BDS2020 (details regarding the relation between BDS2020 and MSP are found in Appendix 13).

The environmental state of the sea is largely influenced by transboundary pressures, and many problems need to be tackled in international cooperation, thus both the MSFD and MSPD emphasize the need for harmonization of assessment methods and spatial plans between the member states. For the Nordic countries, including Norway as a non-EU member, international cooperation is particularly relevant given the common challenges and shared marine areas. The Nordic marine areas, stretching from Arctic Barent's Sea north of Norway via the Northeast Atlantic to the Danish straits, to the Baltic Proper and the Bothnian Bay, demonstrate the gradient of different marine ecosystem types. Despite the many differences between the areas in terms of their ecosystem characteristics, the Nordic countries all share the same overarching challenges for maritime spatial planning. A common Nordic understanding of how ecosystem services can be used as a tool in MSP could be a starting point in meeting these challenges. 
Current research and recent investigations, to which members of this project team has contributed, have started to build up analytical frameworks for integrating ecosystem services into marine management. For example, the NCM-funded project MARECOS investigated linkages between the indicators for the MSFD descriptors of good environmental status (GES) and ecosystem services (Hasler et al. 2016). These linkages are needed as a starting point in order to analyze benefits of an improved environmental status, as well as the costs associated with degradation. Since the policy framework around both WFD and MSFD is centered on reaching Good Environmental Status (GES), the indicators and descriptors are an important logical node for assessments. For MSPD, a similarly important analytical node is the human marine activities. In this project, we will provide a framework for ecosystem services assessments in relation to maritime spatial planning by linking human activities with their impact on ecosystem services. Two natural starting points for this assessment are: 1) the need to account for varying classifications of ecosystem services, either by choosing one of them for the analysis, or by setting up a framework suitable for several classifications (Hasler et al., 2016), and 2) the concept of intermediate and final ecosystem services (e.g. Boyd \& Banzhaf, 2007 or UK NEA, 2011) vs. ecosystem functions, structures and processes (Hasler et al., 2016).

\subsection{The role of maritime spatial planning in the management of the marine environment}

The Maritime Spatial Planning Directive deals with the spatial planning and management of human activities. The Article 4 of the MSPD states: "When establishing maritime spatial planning, Member States shall have due regard to the particularities of the marine regions, relevant existing and future activities and uses and their impacts on the environment, as well as to natural resources." These activities and uses are closely related to the ecosystem goods and services derived from them.

The goal of MSPD is to allocate the maritime activities in a way that they will not conflict with each other and with the marine ecosystem, and to allow sustainable utilization of marine resources and marine space protection of the marine ecosystem and its services. MSPD should apply an ecosystem-based approach (which is defined in the MSFD) with the aim of ensuring that the collective pressure of all activities is kept within levels compatible with the achievement of good environmental status. Mapping of marine ecosystem services is a prerequisite for their consequent assessment, hence, for preparing environmentally and societally relevant plans for the use of marine resources, i.e. maritime spatial plans. 


\subsubsection{Zoning of the marine areas}

Maritime Spatial Planning is expected to include a system of zoning, to at least some degree. "Ocean zoning" (Fyhr et al. 2013, Agardy et al., 2003) is used in many countries to delineate specific areas for human activities, for example licensing of marine aggregate extraction or oil and gas exploration.

In marine areas, different zones can be allocated for maritime traffic, security zones for ports and waterways, safety zones around maritime installations, military exercise zones, dredging sites, vulnerable habitat protection and conservation designations or aquaculture areas. In multi-use zoning schemes, which are often used within Marine Protection Areas, zones may be designated with regard to the degree of the general use permitted. Zones may operate across geographical areas or time periods to minimize conflicts in areas when different activities compete on either a spatial or a temporal basis.

Zoning schemes may be part of an MSP system, although it must be emphasized that zoning and MSP are not synonymous. While zoning is the mere designation of a site for a specific purpose, MSP provides a framework for systematic, integrated zoning of competing activities, aiming to solve current as well as future potential conflicts (Blæsbjerg et al. 2009, pp. 16-17).

\subsection{The role of ecosystem services in marine spatial planning}

Maritime spatial planning is intended to promote sustainable usage of the resources of the sea. By reconciling the potentially conflicting needs of different economic sectors, and by safeguarding the structure and functioning of the marine ecosystem, MSP also directly or indirectly supports the provision of ecosystem services provided by the sea.

On the other hand, ecosystem services (ES) have rarely, if ever, been considered in marine spatial planning. The central questions are:

- Is the ecosystem services approach helpful for identifying tradeoffs between competing interests for the use of marine space?

- Does the ecosystem services approach help in deciding how the human activities should be allocated in the sea?

- Does the ecosystem services approach help in discussions between different users if there are conflicting interests in the use of marine space? 
The tools for planning the use of different areas of the coastal and marine areas need to be based on knowledge of the structure and functioning of the ecosystems in the costal and marine areas. According to the spirit of MSFD and MSPD, sustainability of the use of marine resource and space as well as the good ecological status of the ecosystems need to be the objectives of the management plans. It is important in MSP that the sustainability of the ecosystems is the basis for the management plans. For the society, the natural aim is to use all resources, including the marine ones, in a way that maximizes the net benefits to society in the long run. In this respect the ecosystem services approach, which expresses also the indirect and non-commercial societal benefits based on the sustainable functioning of the ecosystems, is considered as a useful tool. Therefore, integrating the economic aspects in a broad sense by using the ecosystem service approach may make the plans more appropriate for decision-making support. There are some examples of economic estimates being added to the MSP process, but so far those have not been fully integrated into the marine spatial planning and decision making process.

One important aim of the MSP is to allocate human activities, resources, and areas, and to manage tradeoffs between different uses from sectors and activities. From the society's perspective tradeoffs, should be made according to the values lost and gained by society of different choices. In such societal evaluations, an ecosystem service approach would seem to be a good methodology. Although the ES approach seems appropriate for this purpose, it does not mean that all marine resources and tradeoffs are easily assessed and valued, this is discussed further in chapter 4 .

The ecosystem services approach may be used in several ways in MSP:

- MSP includes coastal planning and planning of the offshore marine areas within EEZ (Exclusive Economic Zone inside the national jurisdiction). The ecosystem services approach will be useful in the coastal zone as well as the marine areas. However, the marine management plans in the Nordic countries are not required to include the coastal zone, except for activities in the coastal zone that affect the marine areas outside and vice versa.

- The ecosystem services approach may be used by different sectors in order to check where the sector's activities give rise to the largest benefits to society, and where the gains are smaller if it has to give up activities.

- The ecosystem services approach can be useful in order to make visible the tradeoffs between different sectors and activities - in ways of illustrating the gains and losses of different alternatives to society. 
- The ecosystem services approach may be used on different spatial scales and levels of details, and to illustrate the benefits and losses of different scenarios (alternatives for development).

- The ecosystem services approach may be a useful tool if one aims at using MSP as a tool for economic and environmental optimizations of marine plans in the long run - that is, plans for use of areas at sea in order to make the largest net benefits to society in the long run. Even though there exist some examples where valuation of natural capital and ecosystem services has been applied (e.g. InVEST: www.naturalcapitalproject.org) a lot more mapping of values for different uses is needed. Another aspect that needs further attention is that optimization or tradeoffs may be made on different geographical scales - for the country, sea areas (e.g. the Barents Sea and Lofoten area, the Norwegian Sea, and the North Sea and Skagerrak), for a county or a fjord, etc.

\subsubsection{A common scientific basis is essential}

Management plans and updates require common vocabulary between the different institutions that are responsible for reporting. Joint reports are based on published scientific and other documented knowledge available at the time the report is written, and reflect consensus on the part of the participating institutions. This can be particularly important when considering tradeoffs and balance between conservation of marine resources and their sustainable use. An example of the Norwegian management process is illustrated in Figure 1 below. 
Figure 1: Example of cross-sector process in marine spatial planning (could also be seen as an IMMEprocess) ${ }^{6}$

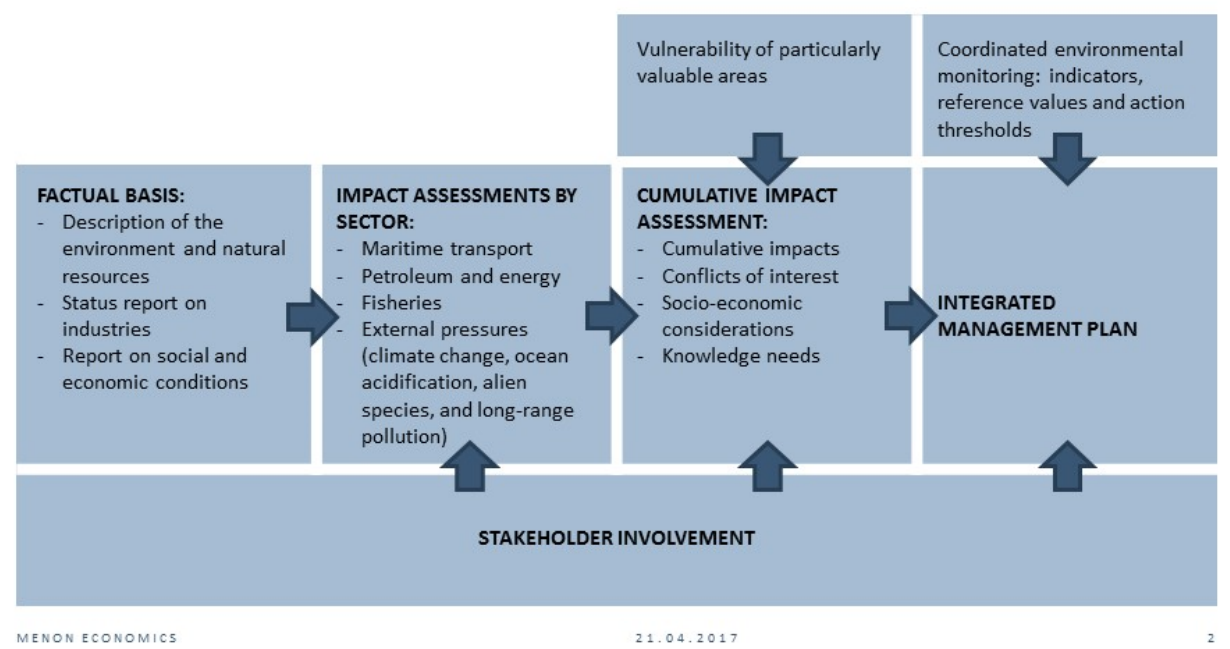

Source: Norwegian Ministry of Climate and Environment.

\subsection{The need for cooperation between the Nordic counties}

The legislation and processes behind marine spatial planning (MSP) processes differ in the Nordic countries. Also, since the ES is a relatively new concept in the context of marine ecosystems, there is no common view on how to take into account ES's in MSP.

On the other hand, the Nordic countries have an excellent position to rise to the forefront of such integration. All countries have a strong tradition in relevant research, including biodiversity, marine socio-economic and cultural analyses.

Because of the varied vocabulary used in ES research, as well as in MSP, it is essential to agree upon common focus and common concepts. Also, necessary practical

\footnotetext{
${ }^{6}$ IMME (Integrated Marine Management for the Environment) means that the cumulative effects of all human activities on the marine environment are considered, and that the management of all these activities is based on consideration of the limits within which the ecosystem structure, its functioning, its productivity and its biological diversity can be sustained. The countries that have introduced IMME have aimed to manage the human activities in marine areas, taking into consideration the ecosystem's limits and the cumulative effects of all human activities. Based on positive experiences to date, IMME has become a recognized approach for ocean management including in several international laws and frameworks such as the Law of the Sea, OSPAR (The Convention for the Protection of the Marine Environment of the North-East Atlantic) and the EU's Marine Strategy Framework Directive.
} 
tools, including GIS/Spatial tools need to be discussed and jointly agreed for smooth cooperation.

Because of the geographic position of the countries, it is also useful to jointly look upon the peculiarities of each of the Nordic Seas. Obviously the Baltic Sea, the Skagerrak, and the Northern Atlantic need to be scrutinized in FI-SE-DK, SE-DK-NO and NO-DK-IS cooperation, respectively.

Also, it will be important to agree upon the spatial scale on which the ES analyses will be made. The scale depends on the goals of the MSP: whether it is meant to aid harmonizing the MSP practises on basin scale, or for spatial planning on a national (coastal) scale.

\subsection{The need for GIS/Spatial tools}

All spatial planning nowadays requires skills on GIS tools. GIS programs are needed for correct placement of spatially arranged data on maps, and for analysis of spatial overlaps and interactions.

This applies also for spatial distribution of ES. The problem is that spatial allocation of ES is not trivial. They need to be tied to some measurable parameters that have a known spatial distribution. Such parameters include habitats (or bottom types and the communities associated with them), species, as well as environmental factors affecting the provision of ES in the sea.

Different types of practical GIS/spatial tools are being developed to aid MSP in several projects. Such tools usually are meant to evaluate the magnitude of overlap of different human activities with each other and with nature values (including ES). Often the tools can be used for solving spatial allocation problems, such as where to place a windmill park in order to create most electricity but at the same time cause minimal harm for other sectors and the nature (including ES). A few examples GIS-based tools are InVEST (www.naturalcapitalproject.org) and Marxan (Watts et al. 2009).

The success of such MSP tools is entirely dependent on the availability of reliable and spatially sufficiently dense data. Usually spatial grids that cover the whole study area are needed. To create such grids, the raw data on the relevant parameters (species, habitats, geological properties, topography, and human activities) need to be sufficiently dense. The spatial layers can then be created with various methods, either by interpolation, or by models that vary in detail and sophistication.

However, the success of GIS/Spatial tools is entirely dependent on the amount and reliability of the data available. This applies regardless if the tools are designed to MSP purposes, or for evaluation of the spatial provision of ES. Even when proxies or models can be calculated for a particular ES, the reliability of the analysis depend on the quality 
and amount on data on which the proxies are calculated. Often the amount of environmental data can be a limiting factor for a successful spatial analysis.

A relevant goal for the Nordic cooperation in the ES - MSP integration is to assess the availability and usefulness of the data available in each of the countries. Such metadata can be used to steer collection of new data, and determine if the ES-based analyses can be obtained cost-efficiently in the first place.

\subsection{Marine Spatial Planning in the Nordic countries}

There is a difference in approach to planning in the Nordic countries e.g. with regards to proximity to land. E.g. in Norway there is different plans developed for coastal areas compared to the exclusive economic zone. The majority of the opposing interests are also taking place in the coastal zone. In Sweden, the municipalities are responsible for MSP from the shoreline to the baseline, after that to the end of EEZ, the responsible agency is SwAM (Swedish Agency for Marine and Water management). In many countries, the MSP has only recently been adopted in the national legislation, and practices vary from country to country. The legislation and different prerequisites for MSP in the Nordic as well as the other countries surrounding the Baltic Sea are further reviewed in Appendix 7. 



\section{Linkages between maritime activities and ecosystem services}

The process for establishing the connections between marine/maritime activities and marine ecosystem services is guided by a number of steps. The first entails the choice of a suitable typology of ecosystem services to which the activities should be linked. At present, there are a number of overarching classification systems, some with thematic specifications available. For the practical tool, we suggest a typology of marine ecosystem services stemming from TEEB (TEEB 2010a) and put forward by BöhnkeHenrichs et al. (2013), see section 3.1 below.

The second step concerns the identification and definition of the marine/maritime activities and sectors that might be included in the analysis. Again, a number of suggestions for classifications and division of the marine/maritime sectors have been suggested in different EU member states (Surís-Regueiro et al. 2013) to underpin the implementation of marine environmental policy, i.e. The Marine Strategy Framework Directive (2008/56/EC). For use in the practical tool, we suggest the classification put forward by the European commission in the revision of annex III to the MSFD. This step also includes the identification of environmental pressures associated with the activities in the sectors. The classification of environmental pressures used is based on technical background documents for the revision of annex III to the Marine Strategy Frameworks Directive (2008/56/EC), see section 3.2.

In the third step, the environmental pressures identified and compiled in the second step are used to identify affected ecosystem services in the policy area, see section 3.3 .

The three steps briefly described above lay the ground for assessing the impact on the provision and quality of ecosystem services that may result from different planning scenarios. By adopting a methodology focusing on selecting activities, pressures and ecosystem services exclusively relevant for the policy area, the scope of the analysis becomes narrowed down and manageable, see section 3.4. This facilitates the continued assessment described in section 4 , i.e. assessment of changes in the provision and quality of ecosystem services resulting from the environmental pressures, economic valuation of those changes, and finally, tradeoffs between different ecosystem services. 


\subsection{Listing of marine ecosystem services and indicators}

There are a number of different ecosystem services classification systems that categorize different ecosystem services at the international and EU level, as well as in individual countries. These service categorizations have been developed for different purposes, and are often meant to cover all ecosystem types (terrestrial, aquatic and marine) in comparable manners to support assessments.

\subsubsection{Different classification systems - strengths and weaknesses}

The most frequently used classification systems are the Millennium Ecosystem Assessment (MEA, 2005), the Economics of Ecosystems and Biodiversity (TEEB, 2010b), and the EU-level proposal for the Common International Classification of Ecosystem Services (CICES) (http://www.cices.org) developed for the purpose of the EU Biodiversity Strategy implementation by the MAES working group; Mapping and Assessments of Ecosystem Services (Maes et al. 2013, 2014). Moreover, the UK National Ecosystem Assessment (UK NEA, 2011) and specifically the UK National Ecosystem Assessment Follow On (UK NEAFO, Turner et al. 2014) address marine ecosystem services.

An evaluation of the different ecosystem services assessment approaches and classification systems for the marine environment was recently carried out in the Nordic countries (Hasler et al. 2016). They concluded that the CICES, MAES, UK NEA (including developments within UK NEAFO) approaches are most appropriate to assess the value of ecosystem services in the marine environment where the marginal changes of the ecosystem services are of interest (Table 1). 
Table 1: Strengths and weaknesses of the marine ecosystem services classifications

Strengths

MEA

Defined ecosystem services, high policy impact.

TEEB

Avoids risk of double counting by focusing on final services. Habitat services are included as separate category. TEEB are currently developing a TEEB Ocean concept and assessment.

CICES Avoids risk of double counting by distinguishing clearly between intermediate and final services Complementary tables for abiotic outputs can be developed

MAES MAES applies the concepts of TEEB and CICES, and focuses on the mapping of the ecosystems. Develops and uses consistent links between ecosystem structures and functions to the values of the ES.

UK NEA Concept is inspiring for scenario and policy assessments, tradeoffs between ecosystem services.

\section{Weaknesses}

Double-counting, not dealing with changes.

Not explicitly dealing with scenarios and changes.

Not explicitly dealing with scenarios and changes. Very detailed, and can be difficult to have an overview of the many classes and categories.

Source: Hasler et al. 2016

Both TEEB and CICES categorise the services into provisioning, regulating, and cultural services. The main difference between the CICES and TEEB classifications is in the treatment of "habitat services", which is a distinct grouping at TEEB, but a part of "regulating and maintenance" services in CICES. Table 2 from Hasler et al. shows a comparison between CICES ecosystem services and TEEB categories. 
Table 2: CICES ecosystem services division compared with the TEEB categories

\begin{tabular}{|c|c|c|c|c|c|}
\hline CICES Section & CICES Division & \multicolumn{4}{|c|}{ TEEB Categories } \\
\hline \multirow[t]{4}{*}{ Provisioning } & Nutrition & Food & & & \\
\hline & & Water & & & \\
\hline & Materials & Raw materials & Genetic resources & $\begin{array}{l}\text { Medicinal } \\
\text { resources }\end{array}$ & $\begin{array}{l}\text { Ornamental } \\
\text { resources }\end{array}$ \\
\hline & Energy & & & & \\
\hline \multirow[t]{4}{*}{$\begin{array}{l}\text { Regulating and } \\
\text { Maintenance }\end{array}$} & Meditation of waste & Air purification & $\begin{array}{l}\text { Waste treatment } \\
\text { (esp. water } \\
\text { purification) }\end{array}$ & & \\
\hline & Mediation of flows & $\begin{array}{l}\text { Disturbance } \\
\text { prevention or } \\
\text { moderation }\end{array}$ & $\begin{array}{l}\text { Regulation of water } \\
\text { flows }\end{array}$ & $\begin{array}{l}\text { Erosion } \\
\text { prevention }\end{array}$ & \\
\hline & $\begin{array}{l}\text { Maintenance of physical, } \\
\text { chemical, biological } \\
\text { conditions }\end{array}$ & $\begin{array}{l}\text { Climate regulation } \\
\text { (incl. C-sequestration) }\end{array}$ & $\begin{array}{l}\text { Maintaining soil } \\
\text { fertility }\end{array}$ & & \\
\hline & & Gene pool protection & $\begin{array}{l}\text { Lifecycle } \\
\text { maintenance }\end{array}$ & Pollination & Biological control \\
\hline \multirow[t]{2}{*}{ Cultural } & $\begin{array}{l}\text { Physical and intellectual } \\
\text { interactions with biota, } \\
\text { ecosystems, and land- } \\
\text { /seascapes }\end{array}$ & Aesthetic information & $\begin{array}{l}\text { Inspiration for } \\
\text { culture, art and } \\
\text { design }\end{array}$ & $\begin{array}{l}\text { Recreation and } \\
\text { tourism }\end{array}$ & \\
\hline & $\begin{array}{l}\text { Spiritual, symbolic and other } \\
\text { interactions with biota, } \\
\text { ecosystems, and land- } \\
\text { /seascapes }\end{array}$ & Spiritual experience & & & \\
\hline
\end{tabular}

Note: Hasler et al. (2016) present the relevant marine ecosystem services according to CICES, see appendix 1.

Source: Hasler et al. 2016.

The EU project OPENNESS has developed an ecosystem services typology translator (see http://www.openness-project.eu/), which can be used to provide a quick overview how the different ecosystem service types used in CICES can be transferred to equivalent MEA, TEEB or UK NEA services. 


\subsubsection{Choosing a classification system for marine ecosystem services and MSP}

The TEEB classification has been adapted for marine ecosystems and updated for the purpose on marine spatial planning and management, Böhnke-Henrichs et al. (2013). It is stated that:

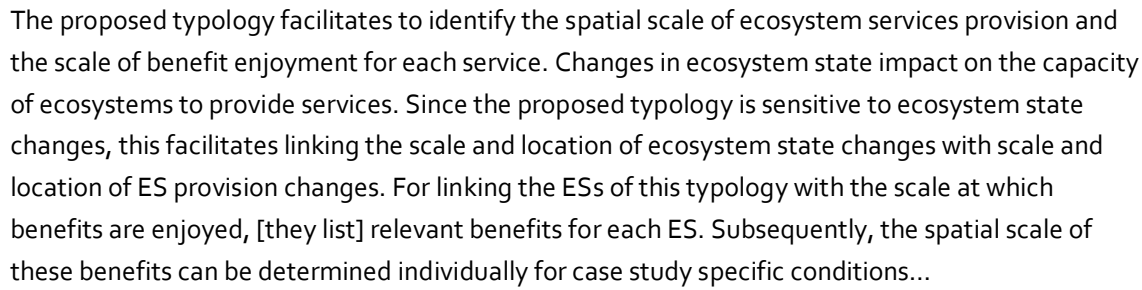

(Böhnke-Henrichs et al. 2013)

The list of relevant benefits for each ecosystem service as suggested by BöhnkeHenrichs et al. (2013) is provided in Table 6 below.

Selection of one classification over another is dependent on the purpose and operational applicability into the ecosystem type or regions in question. For instance, Hattam et al. (2015) stated: "Classification systems need to be suited to the policy and management problem at hand, and different interpretations may be needed depending on the context". Based on adaptation of the existing ES classification systems, they developed an operational ecosystem services classification system for the Dogger Bank in the North Sea. They stressed that "distinguishing between ecosystem functions, services and benefits is important", and decided to use the TEEB classification as a starting point with modifications suggested by Böhnke-Henrichs et al. (2013). Further, using expert judgement they evaluated the relevance of each ecosystem services for coastal, near- and off-shore environment and examined whether the marine environment and the Dogger Bank could actually generate the ecosystem services identified.

Based on the justifications above, we considered the approach by Böhnke-Henrichs et al. (2013) to be appropriate as a starting point for the selection of ecosystem services and identification of indicators for those, as well as the use and beneficiaries (Table 6), and thus linking ecosystem services to MSP scenarios. A sufficiently generic classification based on this system could be developed and tested in the areas where the MSP planning tool would be applied.

We propose the following list of ecosystem services (Table 3 ) as a starting point for identification of the relevant ecosystem services to be linked to the tool development. The list of TEEB ecosystem services modified by Böhnke-Henrichs et al. (2013) were compared with other ecosystem service classification and evaluated by the experts of 
the Finnish Environment Institutes' marine research centre using the Gulf of Finland, Baltic Sea, as a case study. The evaluation process and the final simplified list is presented in Appendix 2.

In MSP, abiotic resources are also of importance. Sectors exploiting abiotic resources may also affect biotic resources and therefore we suggest that abiotic resources are included in the ecosystem services categorization as suggested by CICES. 


\section{Table 3: An adapted ecosystem services classification, suggested to be used in the marine spatial planning and linked with the MSP tool}

\begin{tabular}{|c|c|c|}
\hline Section & Ecosystem service & Description and examples \\
\hline \multirow[t]{6}{*}{$\begin{array}{l}\text { Provisioning } \\
\text { services }\end{array}$} & Sea food & $\begin{array}{l}\text { All available marine fauna and flora extracted from coastal/marine environments for the specific purpose of human consumption as food (i.e. excludi } \\
\text { for consumption as supplements). }\end{array}$ \\
\hline & Sea water & $\begin{array}{l}\text { Sea water in oceans, seas and inland seas that is extracted for use in human industry and economic activity. Used for in shipping, industrial cooling, } \\
\text { desalinization. }\end{array}$ \\
\hline & Raw materials & The extraction of any material from coastal/ marine environments, excluding ornamental resources, such as algae (non-food), sand, salt. \\
\hline & $\begin{array}{l}\text { Genetic } \\
\text { resources }\end{array}$ & $\begin{array}{l}\text { The extraction of genetic material from marine flora and fauna for use in non-marine, non-medicinal contexts, excluding the research value on Gene } \\
\text { Resources for cognitive development. The use of marine flora/fauna-derived genetic material to improve crop resistance to saline conditions. }\end{array}$ \\
\hline & $\begin{array}{l}\text { Medicinal } \\
\text { resources }\end{array}$ & $\begin{array}{l}\text { Any material that is extracted from the marine environment to provide medicinal benefits, Marine-derived pharmaceuticals and salt-water used for } \\
\text { health purposes. }\end{array}$ \\
\hline & Ornamental resources & Any material extracted for use in decoration, fashion, handicrafts, souvenirs, etc., Shells, aquarium fish, pearls, coral. \\
\hline \multirow[t]{8}{*}{$\begin{array}{l}\text { Regulating } \\
\text { services }\end{array}$} & Air purification & $\begin{array}{l}\text { Air Purification provided by a coastal and marine ecosystem, The removal of pollutants like fine dust and particular matter, sulphur dioxide, carbon } \\
\text { dioxide, etc. from the air. }\end{array}$ \\
\hline & $\begin{array}{l}\text { Climate } \\
\text { regulation }\end{array}$ & $\begin{array}{l}\text { The contribution of the biotic elements of a coastal/marine ecosystem to the maintenance of a favourable climate via their impact on the hydrologica } \\
\text { cycle and their contribution to the climate-influencing substances in the atmosphere, for example the production, consumption and use by marine } \\
\text { organisms of gases such as carbon dioxide, water vapour, nitrous oxides, methane, and dimethyl sulphide. }\end{array}$ \\
\hline & $\begin{array}{l}\text { Disturbance } \\
\text { prevention or } \\
\text { moderation }\end{array}$ & $\begin{array}{l}\text { The production, consumption and use by marine organisms of gases such as carbon dioxide, water vapour, nitrous oxides, methane, and dimethyl } \\
\text { sulphide; The reduction in the intensity of and/or damage caused by environmental disturbances resulting directly from marine ecosystem structures } \\
\text { salt marshes, sea grass beds, and mangroves. }\end{array}$ \\
\hline & $\begin{array}{l}\text { Regulation of water } \\
\text { flows }\end{array}$ & $\begin{array}{l}\text { The contribution of marine and coastal ecosystems to the maintenance of localized coastal current structures. The effect of macro algae on localized } \\
\text { current intensity; The maintenance of deep channels by coastal currents which are for shipping. }\end{array}$ \\
\hline & Nutrient regulation *) & The removal of nutrients in coastal/marine ecosystems from waste water and riverine loadings by sedimentation, and accumulation, denitrification, \\
\hline & $\begin{array}{l}\text { Waste } \\
\text { treatment }\end{array}$ & $\begin{array}{l}\text { The removal by coastal/marine ecosystems of pollutants added to coastal/marine environments by humans through processes such as storage, burial } \\
\text { and biochemical recycling. The breakdown of chemical pollutants by marine microorganisms; The filtering of coastal water by shell fish. }\end{array}$ \\
\hline & $\begin{array}{l}\text { Coastal erosion } \\
\text { prevention }\end{array}$ & $\begin{array}{l}\text { The contribution of coastal/marine ecosystems to Coastal Erosion Prevention, excluding what is covered by regulation of water flow service (i.e. } \\
\text { transportation or deposition of sediments by coastal currents). }\end{array}$ \\
\hline & Biological control & $\begin{array}{l}\text { The contribution of marine/coastal ecosystems to the maintenance of natural healthy population dynamics to support ecosystem resilience through } \\
\text { maintaining food web structure and flows. The support of reef ecosystems by herbivorous fish that keep algae populations in check; the role that top }\end{array}$ \\
\hline
\end{tabular}

predators play in limiting the population sizes of opportunistic species like jelly fish and squid. 
Habitat services Lifecycle

(Regulating

maintenance

Gene poo

protection

Cultural services Recreation

and leisure

Inspiration and Culture

Art and Design

Cultural heritage and

identity

Aesthetic

information/ Landscape

Information

for cognitive

development

Spiritual

experience
The contribution of a particular habitat to migratory species' populations through the provision of essential habitat for reproduction and juvenile maturation. The reproduction habitat of commercially valuable species that are harvested elsewhere.

The contribution of marine habitats to the maintenance of viable gene pools through natural selection/evolutionary processes. Inter- and Intra-specific genetic diversity that is supported by marine ecosystems which enhances adaptability of species to environmental changes.

The provision of opportunities for Recreation and Leisure that depend on a particular state of marine/coastal ecosystems. Bird/whale/-watching, beachcombing, sailing, recreational fishing, SCUBA diving, etc.

The contribution that a coastal/marine ecosystem makes to the existence of environmental features that inspire elements of culture, art, and/or design The use of a marine landscape as a motif in paintings; The use of marine environmental features (like waves) in jewellery; for instance, construction of buildings according to a marine inspired theme; the use of marine organisms or marine ecosystems in films (including Jaws and Finding Nemo).

The contribution that a coastal/marine ecosystem makes to Cultural Heritage and Identity (excluding aesthetic and formal religious experiences). This includes the importance of marine/coastal environments in cultural traditions and folklore. This covers the appreciation of a coastal community for loca coastal/marine environments and ecosystems (e.g. for a particular coast line or cliff formation) as well as the global importance that may be associated with a particular marine landscape. For instance, the Wadden Sea is listed as UNESCO World Heritage site.

The contribution that a coastal/marine ecosystem makes to the existence of a surface or subsurface landscape that generates a noticeable emotional response within the individual observer. This includes informal Spiritual Experiences. The particular visual facets of a "sea-scape" (like open "blue" water), a "reef-scape" (with abundant and colourful marine life), a "beachscape" (with open sand), etc. that emotionally resonate with individual observers.

The contribution that a coastal/marine ecosystem makes to education, research, etc. This includes the contribution that a coastal/ marine ecosystem makes to bionic design and biomimetics and to research on applications of marine Genetic Resources and pharmaceuticals. The environmental education of children and adults; The development of surfaces to reduce marine biofouling based on similar surfaces found in marine environments; the application of hydrodynamic flow analysis to marine animals for ship design; Utilization of marine animal swimming mechanisms in engineering design.

The contribution that a coastal/marine ecosystem makes to religious experiences. Several Greek and Roman gods were connected to the sea; A prominent Christian symbol is the fish; Marine organisms (such as whales and salmon) sometimes play important roles in various indigenous communities' religion.

Note: This is based on TEEB and modified from Böhnke-Henrichs et al. (2013).

*) Nutrient regulation was added as a specific ecosystem service category, and it was not considered to be part of the Waste Treatment. Deterioration of the nutrient regulation service can be seen as increase of eutrophication impacts in the Nordic coastal areas. 


\subsubsection{Ecosystem services indicators}

In order to operationalize the use of ecosystem services as a decision support tool, and to facilitate the analysis of changes in the flow of services from the ecosystems to society, different sets of ecosystem services indicators have been developed for different contexts. In the case of marine ecosystem services, both MAES and TEEB suggest indicators to be used in ecosystem services analysis (Tables 4 and 5 below). The latter is not primarily focusing on marine application but is included to illustrate how indicators are used in other ecosystem services typologies.

Table 4: Marine ecosystem services and associated indicators according to MAES

\begin{tabular}{|c|c|c|}
\hline Service division & Service & Indicator (unit) \\
\hline Nutrition. & Wild fish and their outputs. & $\begin{array}{l}\text { Landings (ton) and Catch per unit } \\
\text { effort (CPUE; ton). }\end{array}$ \\
\hline $\begin{array}{l}\text { Mediation of waste, toxics and other } \\
\text { nuisances. }\end{array}$ & Mediation by biota. & Nutrient load to coast (ton/year). \\
\hline $\begin{array}{l}\text { Maintenance of physical, chemical } \\
\text { and biological conditions. }\end{array}$ & $\begin{array}{l}\text { Maintaining nursery populations and } \\
\text { habitats. }\end{array}$ & $\begin{array}{l}\text { Oxygen concentration }(\%) \\
\text { Species distribution }\left(\mathrm{km}^{2} / \mathrm{ha}\right) \\
\text { Abundance and richness - at age } \\
\text { (ton/year). Extent of marine } \\
\text { protected areas }\left(\mathrm{km}^{2} / \mathrm{ha}\right) .\end{array}$ \\
\hline $\begin{array}{l}\text { Maintenance of physical, chemical } \\
\text { and biological conditions. }\end{array}$ & Pest control. & $\begin{array}{l}\text { Presence of alien species (no.) } \\
\text { Distribution of alien species }\left(\mathrm{km}^{2}\right) \text {. }\end{array}$ \\
\hline $\begin{array}{l}\text { Maintenance of physical, chemical } \\
\text { and biological conditions. }\end{array}$ & Chemical conditions of sea water. & $\begin{array}{l}\text { Nutrient load to coast (ton/year) } \\
\text { Heavy metal and persistent organic } \\
\text { pollutant loading (ton/year). }\end{array}$ \\
\hline $\begin{array}{l}\text { Physical and intellectual interactions } \\
\text { with biota, ecosystems, and land- } \\
\text { /seascapes [environmental settings]. }\end{array}$ & $\begin{array}{l}\text { Experiential use of plants, animals } \\
\text { and land-/seascapes in different } \\
\text { environmental settings. }\end{array}$ & $\begin{array}{l}\text { Extent of marine protected areas } \\
\left(\mathrm{km}^{2} / \mathrm{ha}\right) \\
\text { Presence of iconic/endangered } \\
\text { species (no.). }\end{array}$ \\
\hline $\begin{array}{l}\text { Spiritual, symbolic and other } \\
\text { interactions with biota, ecosystems, } \\
\text { and land-/seascapes [environmental } \\
\text { settings]. }\end{array}$ & Existence/Bequest. & $\begin{array}{l}\text { Extent of marine protected areas } \\
\left(\mathrm{km}^{2} / \mathrm{ha}\right) \\
\text { Presence of iconic/endangered } \\
\text { species (no.). }\end{array}$ \\
\hline
\end{tabular}

Source: MAES et al. 2016. 
Table 5: Ecosystem services categories, services and examples of indicators used in TEEB

Ecosystem services

Ecosystem service indicator

Provisioning services.

Sustainably produced and harvested crops, fruit, wild berries, fungi, nuts, livestock, semi-domestic animals, game, fish and other aquatic resources.

Water quantity.

Raw materials: sustainably produced/harvested wool, skins, leather, plant fiber (cotton, straw etc.), timber, cork firewood, biomass, etc.

Regulating services.

Climate/climate change regulation, carbon sequestration, maintaining and controlling temperature and precipitation. Moderation of extreme events: flood control, drought mitigation.

Water regulation: regulating surface water runoff, aquifer recharge etc.

Water purification and waste management: decomposition/capture of nutrient and contaminants, prevention of eutrophication of water bodies etc.

Erosion control; maintenance of nutrients and soil cover and preventing negative effects of erosion (e.g. impoverishing of soil, increased sedimentation of water bodies).

Cultural and social services

Landscape and amenity values: amenity of the ecosystem, cultural diversity and identity, spiritual values, cultural heritage values etc.

Ecotourism and recreation; hiking camping, nature walks, jogging, skiing, canoeing, rafting, recreational fishing, diving, animal watching etc.

Cultural values and inspirational services: e.g. education, art and research.

Source: Hasler et al. 2016.
Crop production from sustainable (organic) sources in tons and/or hectares. Livestock from sustainable (organic) sources in tons/numbers. Fish production from sustainable (organic) sources in tons live weight (proportion of fish stocks caught within safe biological limits).

Total freshwater resources in millions of $\mathrm{m}^{3}$.

Timber for construction (millions of $\mathrm{m}^{3}$ of natural and/or sustainably managed forests).

Trends in numbers of damaging natural disasters, Probability of incident.

Infiltration capacity/rate of an ecosystem (e.g. amount of water/surface area - volume through unit area/per time Soil water storage capacity $\mathrm{mm} / \mathrm{m}$, floodplain water storage capacity in $\mathrm{mm} / \mathrm{m}$.

Removal of nutrients by wetlands (tons or percentage) Water quality in aquatic ecosystems (sediment, turbidity/phosphorus, nutrients etc.).

Soil erosion rate by land use type.

Changes in the number of residents and real estate values.

Number of visitors to sites per year. Amount of nature tourism.

Total number of educational excursions at a site. Number of TV programs, studies, books etc. featuring sites and the surrounding area, number of scientific articles and patents. 
Table 6: Generic marine indicators for ecosystem services and examples of measurement units (from Hattam et al. 2015) as well as equivalent indicators suggested by Maes et al. (2016). Examples of direct benefits are from Böhnke-Henrichs et al. (2013). Some services which were not considered relevant were excluded from this table

\begin{tabular}{|c|c|c|c|c|}
\hline $\begin{array}{l}\text { Ecosystem } \\
\text { Service }\end{array}$ & $\begin{array}{l}\text { Generic marine } \\
\text { ecosystem } \\
\text { service indicators }\end{array}$ & $\begin{array}{l}\text { Measurement (units) } \\
\text { - measured over } \\
\text { time }\end{array}$ & $\begin{array}{l}\text { Equivalent MAES } \\
\text { indicators (unit) }\end{array}$ & $\begin{array}{l}\text { Examples of direct } \\
\text { benefits }\end{array}$ \\
\hline Sea food. & $\begin{array}{l}\text { Fish and shellfish } \\
\text { populations } \\
\text { Seaweed stock amount of } \\
\text { fish landed, harvested. } \\
\text { Quality of the fish, } \\
\text { shellfish, seaweed stock. }\end{array}$ & $\begin{array}{l}\text { Biomass }\left(\text { ton } / \mathrm{km}^{2}\right) \text { or } \\
\text { abundance }\left(\text { no. } / \mathrm{km}^{2}\right) \\
\text { of fish and shellfish; } \\
\text { area }\left(\mathrm{m}^{2}\right) \text { or biomass } \\
\text { (tons } / \mathrm{km}) \text { of } \\
\text { seaweed. } \\
\text { Species composition, } \\
\text { age profile; length } \\
\text { profile; percentage } \\
\text { affected by disease; } \\
\text { mortality rates. }\end{array}$ & $\begin{array}{l}\text { Yield. } \\
\text { Landings (ton). } \\
\text { Catch per unit effort } \\
\text { (CPUE; ton). }\end{array}$ & $\begin{array}{l}\text { Nutrition. } \\
\text { Protein source. } \\
\text { Livelihood. } \\
\text { Pleasure (enjoy the } \\
\text { taste). }\end{array}$ \\
\hline $\begin{array}{l}\text { Farmed sea } \\
\text { food. }\end{array}$ & $\begin{array}{l}\text { Fish and shellfish } \\
\text { populations, seaweed } \\
\text { stock. } \\
\text { Quality of the fish, } \\
\text { shellfish, seaweed stock. }\end{array}$ & $\begin{array}{l}\text { Biomass (ton } / \mathrm{km}^{2} \text { ) or } \\
\text { abundance }\left(\mathrm{no} . / \mathrm{km}^{2}\right. \\
\text { of fish and shellfish; } \\
\text { area }\left(\mathrm{km}^{2}\right) \text { or biomass } \\
\left.\text { (tons } / \mathrm{km}^{2}\right) \text { of } \\
\text { seaweed. } \\
\text { Percentage affected } \\
\text { by disease; mortality } \\
\text { rates. }\end{array}$ & $N / A$ & $\begin{array}{l}\text { Nutrition. } \\
\text { Protein source. } \\
\text { Livelihood. } \\
\text { Pleasure (enjoy the } \\
\text { taste). }\end{array}$ \\
\hline $\begin{array}{l}\text { Sea water } \\
\text { (this was } \\
\text { considered only } \\
\text { by Böhnke- } \\
\text { Henrichs et al. } \\
\text { 2013). }\end{array}$ & $\begin{array}{l}\text { Number of days sea water } \\
\text { is insufficient quality for } \\
\text { desired application. } \\
\text { Amount of sea water } \\
\text { extracted per year per } \\
\text { area. }\end{array}$ & $\mathrm{N} / \mathrm{A}$ & N/A & $\begin{array}{l}\text { Safety (ballast water for } \\
\text { shipping, cooling water } \\
\text { for nuclear power } \\
\text { plants), health, } \\
\text { relaxation (recreation, } \\
\text { leisure). } \\
\text { Drinking water } \\
\text { (desalination). }\end{array}$ \\
\hline $\begin{array}{l}\text { Raw materials } \\
\text { (including biotic } \\
\text { raw material). }\end{array}$ & $\begin{array}{l}\text { Quantity of raw material. } \\
\text { Quality of raw materials. }\end{array}$ & $\begin{array}{l}\text { Total quantity or } \\
\text { biomass available in a } \\
\text { fixed area ( } \mathrm{g} / \mathrm{raw} \\
\text { material) } \\
\text { Concentration of raw } \\
\text { material ( } \mathrm{g} / \mathrm{l} \\
\text { seawater, } \mathrm{g} / \mathrm{m}^{3} \\
\text { sediment). }\end{array}$ & $\mathrm{N} / \mathrm{A}$ & $\begin{array}{l}\text { Inputs to industrial } \\
\text { processes construction } \\
\text { material for } \\
\text { infrastructure, } \\
\text { employment. }\end{array}$ \\
\hline
\end{tabular}




\begin{tabular}{|c|c|c|c|c|}
\hline $\begin{array}{l}\text { Ecosystem } \\
\text { Service }\end{array}$ & $\begin{array}{l}\text { Generic marine } \\
\text { ecosystem } \\
\text { service indicators }\end{array}$ & $\begin{array}{l}\text { Measurement (units) } \\
\text { - measured over } \\
\text { time }\end{array}$ & $\begin{array}{l}\text { Equivalent MAES } \\
\text { indicators (unit) }\end{array}$ & $\begin{array}{l}\text { Examples of direct } \\
\text { benefits }\end{array}$ \\
\hline $\begin{array}{l}\text { Climate } \\
\text { regulation. }\end{array}$ & $\begin{array}{l}\text { Air-sea and sediment- } \\
\text { water fluxes of carbon and } \\
\mathrm{CO}_{2} \text {. } \\
\text { Air-sea fluxes of other } \\
\text { greenhouse gases (e.g., } \\
\text { dimethyl sulfide, } \\
\text { methane, nitrous oxide). } \\
\text { Levels of carbon in } \\
\text { different components of } \\
\text { the marine ecosystem. } \\
\text { Permanence of carbon } \\
\text { sequestration. }\end{array}$ & $\begin{array}{l}\text { Modeled or } \\
\text { empirically } \\
\text { determined fluxes. } \\
\text { Modeled or } \\
\text { empirically } \\
\text { determined carbon } \\
\text { levels: biomass of } \\
\text { carbon dissolved } \\
\text { organic or inorganic } \\
\text { carbon (suspended } \\
\text { organic or inorganic; } \\
\text { buried particulate } \\
\text { organic or inorganic. } \\
\text { Percentage of annual } \\
\text { carbon turnover from } \\
\text { sediments. }\end{array}$ & $\begin{array}{l}\text { Carbon stock. } \\
\text { Carbon sequestration. } \\
\mathrm{pH} . \\
\text { Blue carbon. } \\
\text { Primary production. }\end{array}$ & $\begin{array}{l}\text { Favorable living } \\
\text { conditions, health and } \\
\text { wellbeing. }\end{array}$ \\
\hline $\begin{array}{l}\text { Regulation of } \\
\text { water flows. }\end{array}$ & $\begin{array}{l}\text { Salinity/freshwater input. } \\
\text { Changing shoreline. } \\
\text { Rates of tidal and wind } \\
\text { driven currents. } \\
\text { Seabed morphology. }\end{array}$ & $\begin{array}{l}\text { Change in salinity, } \\
\text { tidal and freshwater } \\
\text { flow rates. } \\
\text { Change in beach } \\
\text { profile (slope } \\
\text { (gradient) and width } \\
\text { and stability) over } \\
\text { time. } \\
\text { Direct measures of } \\
\text { flow and currents and } \\
\text { turbidity. } \\
\text { Changes in seabed } \\
\text { morphology. }\end{array}$ & $\begin{array}{l}\text { Coastal protection } \\
\text { capacity. }\end{array}$ & $\begin{array}{l}\text { Maintenance of natural } \\
\text { shipping lanes, safety, } \\
\text { livelihood (shipping } \\
\text { sector). }\end{array}$ \\
\hline $\begin{array}{l}\text { Waste } \\
\text { treatment and } \\
\text { assimilation. }\end{array}$ & $\begin{array}{l}\text { Absolute levels of waste in } \\
\text { the water column. } \\
\text { Harmful algal bloom } \\
\text { outbreaks. }\end{array}$ & $\begin{array}{l}\text { Chemical analysis } \\
\text { (contaminant } \\
\text { concentrations). } \\
\text { Remote sensing, } \\
\text { water sampling to } \\
\text { detect frequency and } \\
\text { extent; modeling to } \\
\text { determine future } \\
\text { frequency and extent. }\end{array}$ & $\begin{array}{l}\text { Nutrient load to coast } \\
\text { (ton/year). } \\
\text { Heavy metal and } \\
\text { persistent organic } \\
\text { pollutant loading } \\
\text { (ton/year). } \\
\text { Oxyrisk. }\end{array}$ & $\begin{array}{l}\text { Health (via clean sea } \\
\text { water). }\end{array}$ \\
\hline $\begin{array}{l}\text { Coastal erosion } \\
\text { prevention. }\end{array}$ & $\begin{array}{l}\text { Beach profile (slope and } \\
\text { width); extent of } \\
\text { maintenance and } \\
\text { improvement required to } \\
\text { provide protection. }\end{array}$ & $\begin{array}{l}\text { Change in beach } \\
\text { profile (slope } \\
\text { (gradient), width and } \\
\text { stability) over time. }\end{array}$ & $\begin{array}{l}\text { Coastal protection } \\
\text { capacity. }\end{array}$ & $\begin{array}{l}\text { Protection of property } \\
\text { and land (e.g. used for } \\
\text { recreation, coastal } \\
\text { protection, agriculture, } \\
\text { industry), protection of } \\
\text { land/ seascape, mental } \\
\text { and physical health and } \\
\text { wellbeing of coastal } \\
\text { citizens. }\end{array}$ \\
\hline
\end{tabular}




\begin{tabular}{|c|c|c|c|c|}
\hline $\begin{array}{l}\text { Ecosystem } \\
\text { Service }\end{array}$ & $\begin{array}{l}\text { Generic marine } \\
\text { ecosystem } \\
\text { service indicators }\end{array}$ & $\begin{array}{l}\text { Measurement (units) } \\
\text { - measured over } \\
\text { time }\end{array}$ & $\begin{array}{l}\text { Equivalent MAES } \\
\text { indicators (unit) }\end{array}$ & $\begin{array}{l}\text { Examples of direct } \\
\text { benefits }\end{array}$ \\
\hline $\begin{array}{l}\text { Biological } \\
\text { control. }\end{array}$ & $\begin{array}{l}\text { Presence/absence/ } \\
\text { frequency of pests (e.g., } \\
\text { algae blooms, foam on } \\
\text { shores, sea lice on farmed } \\
\text { salmon). }\end{array}$ & $\begin{array}{l}\text { As per generic } \\
\text { indicators specifically } \\
\text { applied to control of } \\
\text { pests and HABs that } \\
\text { affect fish species } \\
\text { utilized by fisheries, } \\
\text { mammals, seabirds } \\
\text { and other marine } \\
\text { organisms occurring } \\
\text { in area. }\end{array}$ & $\begin{array}{l}\text { Presence of alien species } \\
\text { (no.) } \\
\text { Distribution of alien } \\
\text { species }\left(\mathrm{km}^{2}\right) .\end{array}$ & $\begin{array}{l}\text { Health, prevention of } \\
\text { losses of farmed } \\
\text { species. }\end{array}$ \\
\hline $\begin{array}{l}\text { Lifecycle } \\
\text { maintenance } \\
\text { (Migratory and } \\
\text { nursery habitat). }\end{array}$ & $\begin{array}{l}\text { Area of habitat or density } \\
\text { of biogenic habitat } \\
\text { creating species "used" or } \\
\text { identified as important for } \\
\text { nursery or reproduction. } \\
\text { Number and diversity of } \\
\text { species using the area for } \\
\text { nursery or reproduction. }\end{array}$ & $\begin{array}{l}\text { For example, extent } \\
\text { of seagrass, maerl or } \\
\text { kelp beds. } \\
\text { Abundance and } \\
\text { species. } \\
\text { Diversity. }\end{array}$ & $\begin{array}{l}\text { Oxygen concentration } \\
(\%) . \\
\text { Turbidity. } \\
\text { Species distribution } \\
\left(\mathrm{km}^{2} / \mathrm{ha}\right) . \\
\text { Abundance and richness } \\
\text { - at age (ton/year). } \\
\text { Extent of marine } \\
\text { protected areas }\left(\mathrm{km}^{2} / \mathrm{ha}\right) \text {. }\end{array}$ & $\begin{array}{l}\text { Nutrition (via sea food), } \\
\text { health, livelihood, } \\
\text { existence value } \\
\text { satisfaction. }\end{array}$ \\
\hline $\begin{array}{l}\text { Recreation and } \\
\text { leisure. }\end{array}$ & $\begin{array}{l}\text { Sea space available for } \\
\text { recreation. } \\
\text { Number and quality of } \\
\text { beaches. } \\
\text { Water quality. } \\
\text { Abundance and diversity } \\
\text { of key species of } \\
\text { recreational interest. } \\
\text { Area of biotopes of key } \\
\text { interest to recreational } \\
\text { users. }\end{array}$ & $\begin{array}{l}\text { Number of km² of sea } \\
\text { with safe water } \\
\text { quality available for } \\
\text { recreational use. } \\
\text { Number and size of } \\
\text { blue flag beaches. } \\
\text { Chemical analysis } \\
\text { (contaminant } \\
\text { concentrations) and } \\
\text { visual analysis; total } \\
\text { coliforms or other } \\
\text { pathogens (quantity } \\
\text { per milliliter of } \\
\text { water). } \\
\text { For example, extent } \\
\text { of seagrass, maerl or } \\
\text { kelp beds (km²). }\end{array}$ & $\begin{array}{l}\text { Extent of marine } \\
\text { protected areas }\left(\mathrm{km}^{2} / \mathrm{ha}\right) \text {. } \\
\text { Presence of } \\
\text { iconic/endangered } \\
\text { species (no.). }\end{array}$ & $\begin{array}{l}\text { Feeling of relaxation, } \\
\text { pleasure and } \\
\text { enjoyment, health and } \\
\text { wellbeing, happiness, } \\
\text { rejuvenation, } \\
\text { employment. }\end{array}$ \\
\hline $\begin{array}{l}\text { Aesthetic } \\
\text { information. }\end{array}$ & $\begin{array}{l}\text { Uniqueness of a site. } \\
\text { Abundance of key species } \\
\text { of individual interest. } \\
\text { Area of biotopes of key } \\
\text { interest to individuals. }\end{array}$ & $\begin{array}{l}1 / \text { (number of sites } \\
\text { with similar features). } \\
\text { Count data. } \\
\text { For example, extent } \\
\text { of seagrass, maerl or } \\
\text { kelp beds }\left(\mathrm{km}^{2}\right) \text {. }\end{array}$ & $\begin{array}{l}\text { Extent of marine } \\
\text { protected areas }\left(\mathrm{km}^{2} / \mathrm{ha}\right) \text {. } \\
\text { Presence of } \\
\text { iconic/endangered } \\
\text { species. }\end{array}$ & $\begin{array}{l}\text { Pleasure, feelings of } \\
\text { stimulation relaxation, } \\
\text { rejuvenation and } \\
\text { enjoyment. }\end{array}$ \\
\hline $\begin{array}{l}\text { Cultural } \\
\text { heritage and } \\
\text { identity. }\end{array}$ & $\begin{array}{l}\text { Species, habitats or } \\
\text { ecosystems that can } \\
\text { potentially form the core } \\
\text { of contribute to a cultural } \\
\text { custom, rite or way of life. }\end{array}$ & $\begin{array}{l}\text { N/A (Insufficient } \\
\text { information to define } \\
\text { indicators). }\end{array}$ & $\begin{array}{l}\text { Extent of marine } \\
\text { protected areas }\left(\mathrm{km}^{2} / \mathrm{ha}\right) \text {. } \\
\text { Presence of } \\
\text { iconic/endangered } \\
\text { species. }\end{array}$ & $\begin{array}{l}\text { Cultural practices which } \\
\text { define the heritage, } \\
\text { sense of community, } \\
\text { sense of place, } \\
\text { belonging, health and } \\
\text { wellbeing. }\end{array}$ \\
\hline
\end{tabular}




\subsection{Maritime sectors and associated environmental pressures}

The European maritime sector is developing rapidly, recently published estimates indicate that Blue Growth sectors will grow from approximately EUR 488 billion in 2010 to about EUR 600 billion in 2020 (ECORYS, Deltares and OCEANIC, 2012). A problem when quantifying the scale of the blue economy in Europe is however the diversity in definitions used to describe the included sub-sectors, and the statistical representations among member states. Another general problem is availability and quality of data which further complicates strategic decision-making and policy development regarding the management of the marine environment and natural resources (Surís-Regueiro et al. 2013).

In the technical background, outlining the basis for the revision of annex III to the marine strategy framework directive (2008/56/EC), a new indicative list of uses and activities to be considered in the assessment of Art. 8.1c (and where relevant Art. 8.1b.) of maritime activities is suggested. The purpose of the typology is to form the basis for a revised annex III and to offer a harmonised list that can be correlated to the larger group of affected policies, i.e.:

- MSFD Annex III Table 2 (2008).

- MSFD typology for reporting in 2012.

- WFD - 2016 reporting guidance.

- Habitats Directive -2011 reference list.

- Eurostat classification of economic activities (NACE rev2).

- OSPAR - 2014 JAMP.

- ODEMM (FP7 project, Kosse et al. 2011).

This list of maritime activities will be applied in the development of a method for including ecosystem services into MSP, outlined in this report. The following activities and uses are included in the list:

- Energy.

- Mining (extraction non living resources).

- Marine transports.

- Fisheries.

- Hunting. 
- Aquaculture.

- Transport.

- Navigational routes.

- Harbours.

- Pipelines, telecommunication cables.

- Coastal defence.

- Marine tourism and recreation.

- Coastal industries.

- Military defence.

Each of the marine/maritime activities impose pressure on the environment which in turn cause impact on different parts of the ecosystem to varying degrees. The links between individual sectors and associated environmental pressures are discussed in Appendix 8 and summarized in Table 7. The tables are intended to be used as support in identifying and compiling pressures associated with individual marine/maritime sector activities. 
Table 7: The links between marine human activities and environmental pressures according to the proposed revision of annex III to the Marine Strategy Framework Directive (MSFD). The dark (greater pressure) and light (lesser pressure) cells act only as a very general guide as to the relative importance of each pressure for each activity

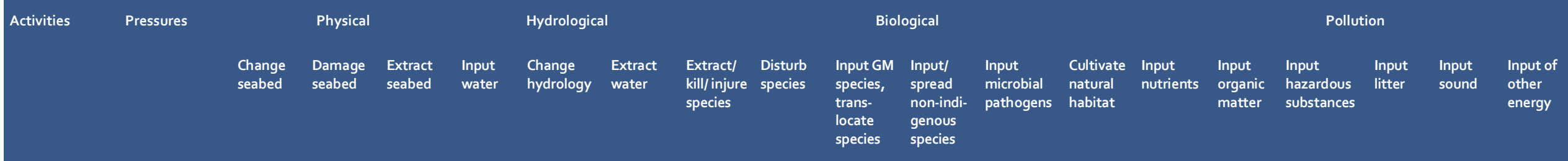
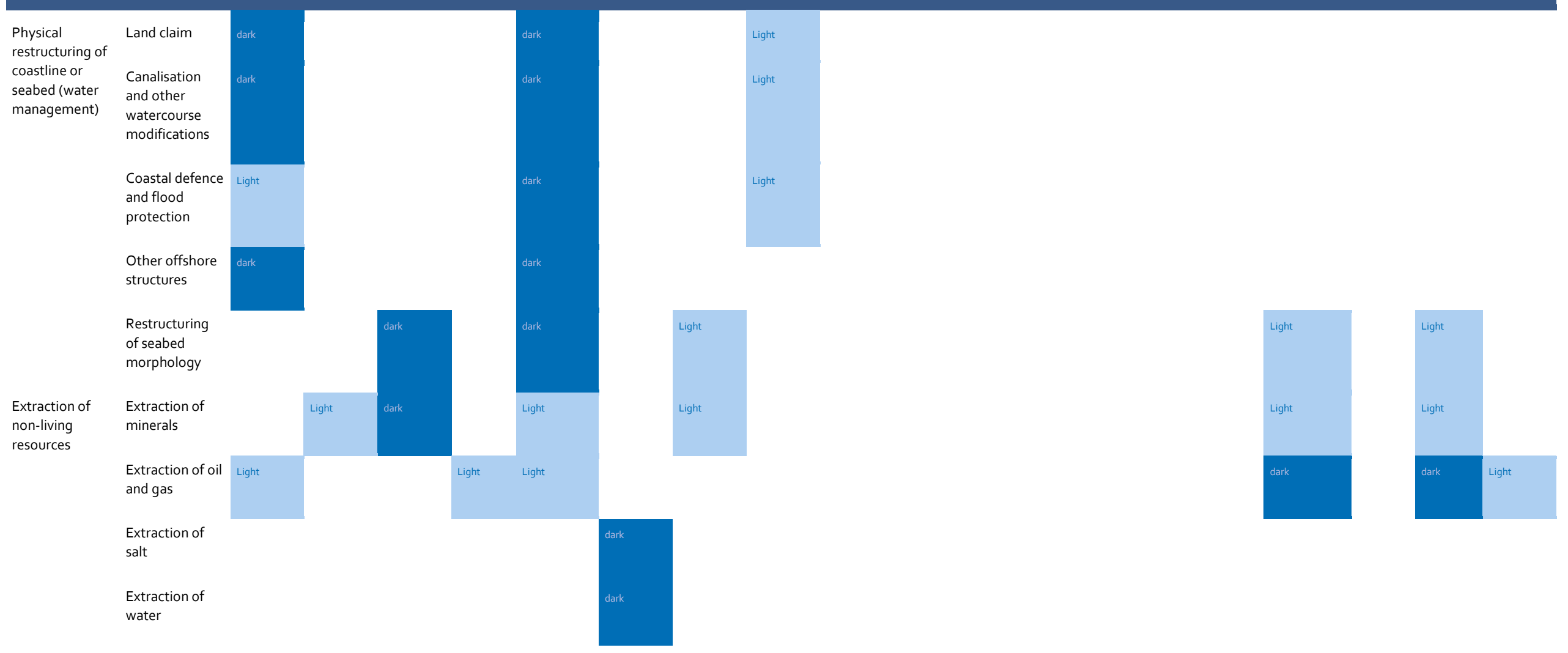


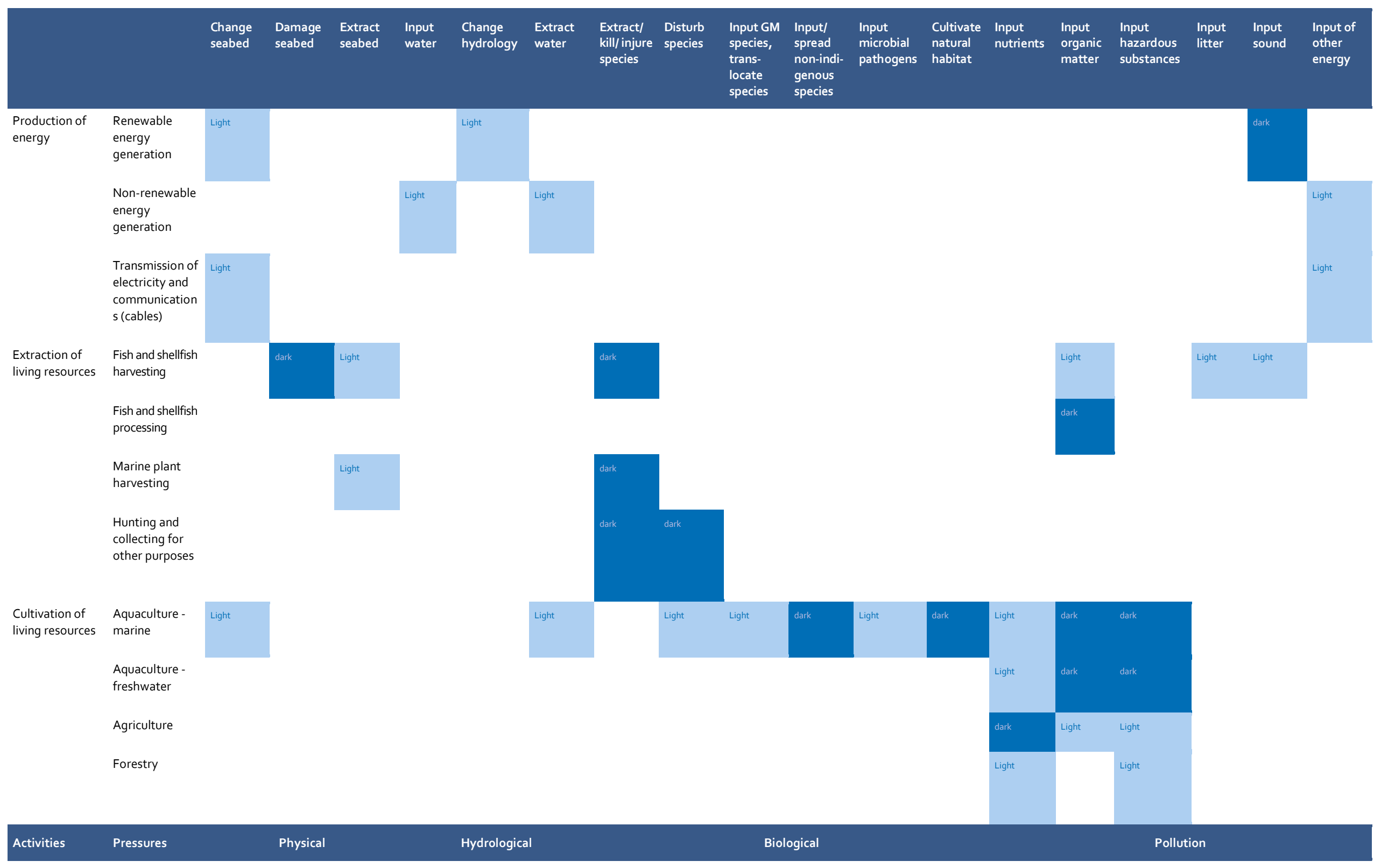




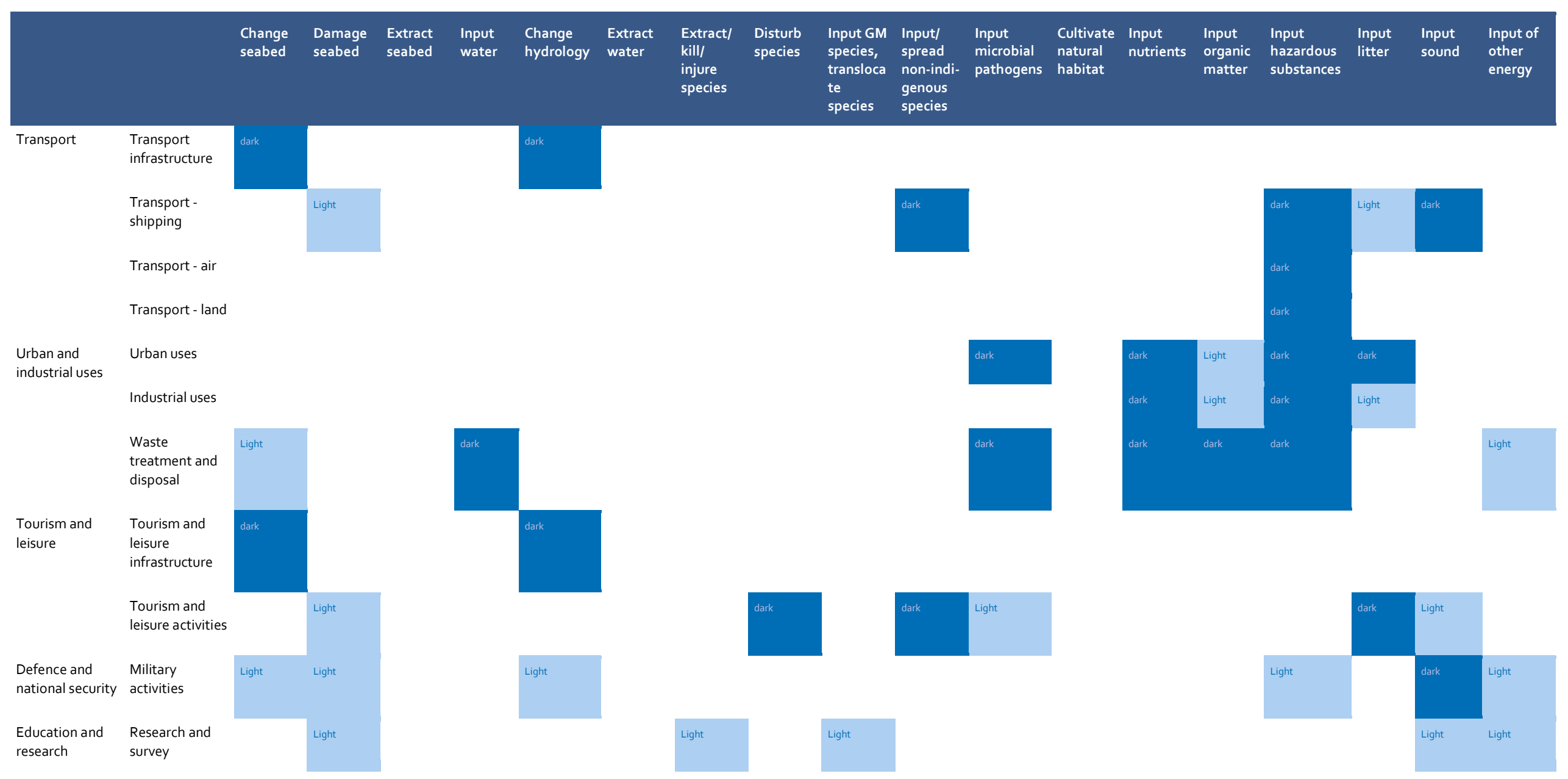

Source: Worksheets of the generic framework of activities, pressures and impacts relevant to the marine environment are found embedded in the documentation of the 14th meeting of the Working Group on Good Environmental Status (WG GES), agenda item 5 .

https://circabc.europa.eu/faces/jsp/extension/wai/navigation/container.jsp?FormPrincipal:_idcl=FormPrincipal:_id_\&FormPrincipal_SUBMIT=1\&id=gb6d36a4-c95e-49af-

8dea8f3cb4482562\&javax.faces.ViewState=tVqJi\%2B5wyAJGhqyzk\%2FYPUSOtsMDN\%2FGOKM7Y34eNPE6OyeoHVqfjjXOKoTK1r2v\%2BhG8aYJ6BW4×W1jorOhc6\%2Bkkivrg9frRLg29y5g1zoxxT6VjAVvEC \%2BKvyn50FO3sbSeX88K6SZ8aAxLD6qHNA4EqZLw90\%3D 


\subsection{Connections between environmental pressures and marine ecosystem services}

The evaluation of the links between pressures and ecosystem services is a qualitative assessment based on the reviews of scientific and other literature, and on the expert opinion of the authors of the documents (SwAM 2012, Bryhn et al. 2015 and Garpe 2008). Sometimes there is a strong evidence in the literature that the impact of a certain pressure on specific ecosystem service is existing, in other cases, there are less evidence and the links are tentative. In Table 8 below, the strength or uncertainty of evidence for specific links are not specified. Moreover, the pressure-impact relation depends on local and regional conditions and characteristics of ecosystems and activities. Each pressure type may result in different levels of impacts on marine ecosystems depending on prevailing species and habitats. Moreover, there are also synergistic and cumulative impacts that are not considered here. Therefore, it is advisable to carry out an activitypressure-impact analysis based the local conditions. The table below provides a guiding framework how to carry out such an analysis. 


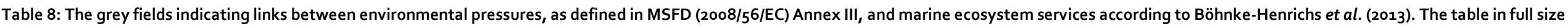
is also found in appendix 3 of this report

\begin{tabular}{|c|c|c|c|c|c|c|c|c|c|c|c|c|c|c|c|c|c|c|c|c|c|c|c|}
\hline \multirow[b]{4}{*}{ Pressure } & \multirow[b]{4}{*}{$\begin{array}{l}\text { Pressure } \\
\text { theme }\end{array}$} & \multicolumn{22}{|c|}{ Ecosystem services } \\
\hline & & \multirow{3}{*}{\begin{tabular}{|l|} 
P1 \\
Sea \\
food
\end{tabular}} & \multicolumn{5}{|c|}{ Provisioning } & \multicolumn{8}{|c|}{ Regulating services } & \multicolumn{2}{|c|}{$\begin{array}{l}\text { Habitat services } \\
\text { (Regulating) }\end{array}$} & \multirow[b]{2}{*}{$\mathrm{C}_{1}$} & & \multicolumn{2}{|c|}{ Cultural service } & \multirow[b]{2}{*}{$C_{5}$} & \multirow[b]{2}{*}{ C6 } \\
\hline & & & $\mathbf{P}_{2}$ & $P_{3}$ & $\mathrm{P}_{4}$ & $P_{5}$ & P6 & $\mathbf{R}_{\mathbf{1}}$ & $\mathbf{R}_{2}$ & $\mathrm{R}_{3}$ & $\mathrm{R}_{4}$ & $\mathbf{R}_{5}$ & R6 & $\mathrm{R}_{7}$ & R8 & $\mathrm{H}_{1}$ & $\mathrm{H}_{2}$ & & $C_{2}$ & $C_{3}$ & $\mathrm{C}_{4}$ & & \\
\hline & & & $\begin{array}{l}\text { Sea } \\
\text { water }\end{array}$ & $\begin{array}{l}\text { Raw } \\
\text { mate- } \\
\text { rial }\end{array}$ & $\begin{array}{l}\text { Genetic } \\
\text { re- } \\
\text { sources } \\
\text { (DNA) }\end{array}$ & $\begin{array}{l}\text { Medicin } \\
\text { al re- } \\
\text { sources }\end{array}$ & $\begin{array}{l}\text { Ornam } \\
\text { ental } \\
\text { re- } \\
\text { sources }\end{array}$ & $\begin{array}{l}\text { Air } \\
\text { purify- } \\
\text { cation }\end{array}$ & $\begin{array}{l}\text { Climate } \\
\text { regu- } \\
\text { lation }\end{array}$ & $\begin{array}{l}\text { Distur- } \\
\text { bance } \\
\text { prevent } \\
\text { ion or } \\
\text { regu- } \\
\text { lation }\end{array}$ & $\begin{array}{l}\text { Regu- } \\
\text { latin of } \\
\text { water } \\
\text { flows }\end{array}$ & $\begin{array}{l}\text { Nu- } \\
\text { trient } \\
\text { regu- } \\
\text { lation }\end{array}$ & $\begin{array}{l}\text { Waste } \\
\text { treat- } \\
\text { ment }\end{array}$ & $\begin{array}{l}\text { Coastal } \\
\text { erosion } \\
\text { prevent } \\
\text { ion }\end{array}$ & $\begin{array}{l}\text { Biologi } \\
\text { cal } \\
\text { control }\end{array}$ & $\begin{array}{l}\text { Life- } \\
\text { cycle } \\
\text { main- } \\
\text { tenace }\end{array}$ & $\begin{array}{l}\text { Gene } \\
\text { pool } \\
\text { protec- } \\
\text { tion }\end{array}$ & $\begin{array}{l}\text { Recre- } \\
\text { ation } \\
\text { and } \\
\text { leisure }\end{array}$ & $\begin{array}{l}\text { Inspira- } \\
\text { tion } \\
\text { and } \\
\text { Culture } \\
\text { Art/ } \\
\text { Design }\end{array}$ & $\begin{array}{l}\text { Cultural } \\
\text { heritag } \\
\text { e and } \\
\text { identity }\end{array}$ & $\begin{array}{l}\text { Aest- } \\
\text { hetic } \\
\text { infor- } \\
\text { mation } \\
\text { /Land- } \\
\text { scape }\end{array}$ & $\begin{array}{l}\text { Infor- } \\
\text { mation } \\
\text { for } \\
\text { cogni- } \\
\text { tive } \\
\text { deve- } \\
\text { lopment }\end{array}$ & $\begin{array}{l}\text { Spiritu } \\
\text { al } \\
\text { Exper- } \\
\text { ience }\end{array}$ \\
\hline \multirow[t]{2}{*}{ Physical } & $\begin{array}{l}\text { Change } \\
\text { seabed }\end{array}$ & & & & & & & & & & & & & & & & & & & & & & \\
\hline & $\begin{array}{l}\text { Damage } \\
\text { seabed }\end{array}$ & & & & & & & & & & & & & & & & & & & & & & \\
\hline
\end{tabular}

Hydrological Input water

Change

hydrology

Extract

water 


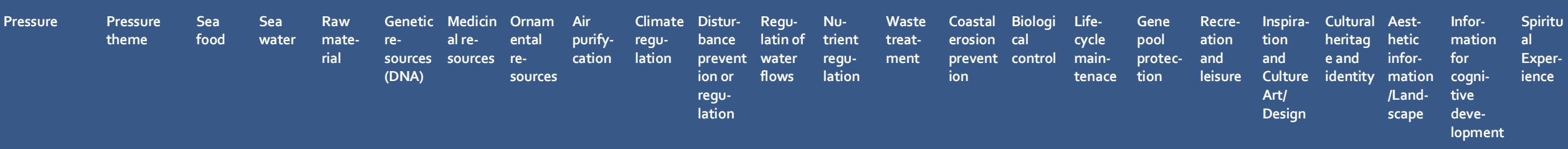

Biological Extract/ kill/

injure

species

Disturb

species

Input GM

species,

translocate

species

Input/

spread non-

indigenous

species

Input

microbial

pathogens

Cultivate

natural

habitat 
Climate Distur- Regu- Nu-

Waste theme food water

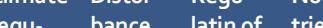

Coastal Biologi Life-

Gene Recre- Inspira- Cultural Aest- Inforerosion cycle pool ation tion heritag hetic mation prevent control main- protec- and and eand infor- for ion tenace tion e and infor- for $\begin{array}{llll}\text { Culture identity mation cogni- } & \\ \text { Art/ } & \text { /Land- tive }\end{array}$ ion or flows lation regu-

Desig Land- tive
scape deve-

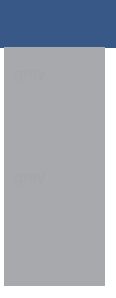

Input

nutrients

Input

organic

Input

hazardous

substances

Input litter

Input sound

Input of

other

energy 


\subsection{A point of departure for a manageable analysis}

The links and connections between the maritime sectors, the environmental pressures they cause and the consequent impacts on the provision and quality of ecosystem services are numerous and therefore practically impossible to list. Most activities give rise to a number of pressures which in turn add to cumulative effects. At the same time, well-functioning ecosystems and the services that those provide often constitute prerequisites for the same activities. The most commonly used example of this bidirectional relationship is commercial fishing, an activity depending entirely on healthy and viable fish stocks. If not managed sustainably fishing will cause a number of environmental pressures affecting the ability of the ecosystem to uphold the provision of the service and thus the long-term profitability of the sector.

In order to facilitate a practical approach to incorporate ecosystem services in the MSPprocess, selections and prioritizations must be made to delimit the analysis. An approach is suggested using the typologies and links presented in the sections 3.1-3.3 above:

- The point of departure for the analysis is the selection of the relevant activities from the classification of marine/maritime activities presented in the section 3.2 (Table 7).

- Compile a list of relevant environmental pressures caused by the activities by making use of the pressure typology presented in Table 7, section 3.2. This will support the identification of a reduced list of pressures to take into account in the continued assessment.

- Identify the affected ecosystem services by making use of the Table 8 in section 3.3 linking pressures to ecosystem services.

After concluding these three steps, a manageable set of activities, environmental pressures and impacts on ecosystem services should have been identified for the continuation of the analysis. 


\section{Practical application of the method}

\subsection{The structure of the tool - a conceptual model}

The application of the tool follows a series of steps covering the process from identification of the policy area to valuation of economic consequences. Commonly this will involve evaluations of economic impact from implementing opposing or alternative planning scenarios in a marine area, it could also be delimited to assessing e.g. the impact on a single sector.

The basic idea in both cases is to track the environmental impacts resulting from the maritime activities involved in the planning scenarios, and on to the impacts on affected ecosystem services. The economic consequences are assessed by valuation of the resulting changes in the provision of the affected ecosystem services.

The objective of the economic valuation is to describe changes in wellbeing, accruing to different stakeholder groups, as a result of different planning scenarios. When possible, this is done by means of monetized values of changes, e.g. changes in net income from fishing due to changes in the availability of fishing grounds. In other cases, changes in wellbeing may have to be described semi-quantitatively (with scores), quantitatively (hectares, tons etc.) or qualitatively (text). The assessment can be considered partly to be a CBA in the sense that it also includes issues, or criteria, outside a traditional $C B A$, e.g. job opportunities and distributional effects. 
Figure 2: A conceptual model of the nine-step methodology

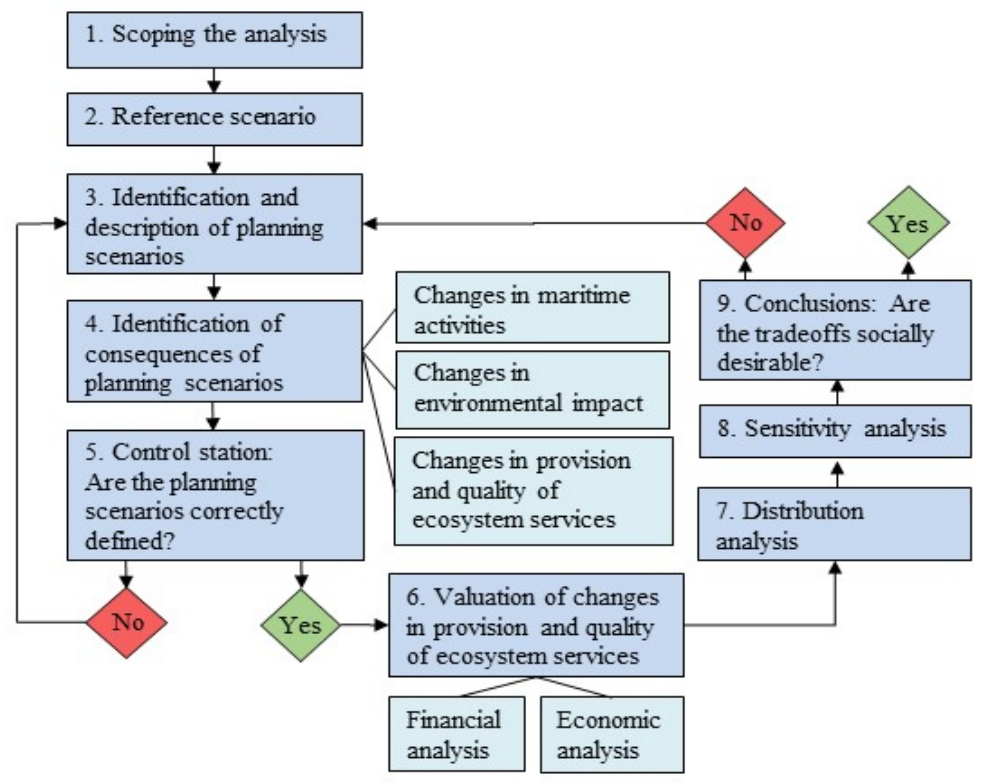

Source: Revised from Kriström and Bonta Bergman, 2014.

\subsection{The need for active participation of stakeholder}

Assessment of impacts on ecosystem services from different activities in the reference scenario and planning scenarios, requires knowledge in many fields of expertise. Hence this assessment ought to be carried out by a group of experts, preferably sitting together and discussing different aspects of the impacts. Further, other stakeholders ought to be included in the process. The aim of the impact assessment is to decide the impact on people's welfare through changes in recreation possibilities, aesthetic effects, non-use values etc., hence stakeholder involvement is important to arrive at agreed impact scores for each ecosystem service.

This is perfectly in line with the intentions and prerequisites in the Water Framework Directive (WFD), Marine Strategy Framework Directive (MSFD), the Marine Spatial Planning Directive (MSPD) and the Aarhus convention.

The organisation of the stakeholder involvement; who should be involved, at which steps in the process etc., must be decided for each planning process and should adhere to the guidelines in the relevant directives, national guidelines and the practical circumstances in each planning project. 


\subsection{Some features of the analysis}

\subsubsection{The Böhnke-Henrichs ecosystem services typology-a gross list}

The ecosystem services typology, adapted to marine spatial planning from TEEB and put forward in Böhnke-Henrichs et al. (2013) is suggested to be used in the analysis. This is a comprehensive list, and we have made some suggestions regarding the ecosystem services considered the most relevant for marine spatial planning applications. Even after this selection of relevant marine ecosystem services, the list is quite comprehensive, and can be used as the "default list" or "reminder" as to which ecosystem services that potentially may be affected in different cases. In practice, it may be helpful if the experts start the assessment by using this list as a check-list for a screening of relevant ecosystem services in the particular area and project. This work includes considering if some ES in the list are not relevant at all in the particular area. Another issue to consider is whether some of the ecosystem services listed should to be combined and assessed together. This may be the case for the habitat services life cycle maintenance and gene pool protection for instance, because there is hardly data or information to separate these two services in marine environment. In other cases, specific ecosystem services may be assessed as one, and some ecosystem services may be screened out.

\subsubsection{Assessing the impact from environmental pressures on the provision and quality of marine ecosystem services}

In order to describe and assess the strength of the impacts from different environmental pressures, a semi-quantitative scoring (scores 1-4) is suggested. The uncertainty in the impact assessments does not justify a more detailed scale than four levels in our opinion. The criteria for assigning impact scores could be a set of questions that should be answered to underpin the assessment. The questions should cover relevant topics e.g. the severity of the impact, the geographical area that is impacted, whether the impact is reversible or irreversible, etc.

To establish the criteria for assigning impact scores, we used the experiences from recent studies conducted for government agencies in Norway that consider applying an ecosystem services (ES) approach in their project appraisal procedures (i.e. Cost-Benefit Analysis including description of non-monetized impacts). We have considered several approaches to designing a scale for these scores, and suggest building on the impact scores developed by www.conservationmesures.org scoring impacts in four categories. We propose using the same system and levels/scores. One should bear in mind, however, that the classification in www.conservationmeasures.org is constructed to assess impacts 
on biodiversity while in this work the focus is to assess the impacts on ecosystem services. The economic value of the impacts is considered at a later stage in the methodology. We therefore focus on criteria relevant for identifying the biophysical impacts of an activity. A detailed description of the approach on how to assess the impact from environmental pressures on ecosystem services are given in Appendix 9.

\subsubsection{Assessing the level of dependency on ecosystem services}

In addition to an impact score, there is also a need for a scale to assess and describe the dependency of various maritime sectors on ecosystem services. The ability to assess the local dependency on ecosystem services will be essential when comparing the overall impact of alternative planning scenarios in order to analyze tradeoffs and make the socially most desirable decisions. It is, however, beyond the scope of this report to carry out assessments of a level of dependency on ecosystem services for specific maritime activities. However, in Appendix 10 we present an approach on how the dependency assessments could be done using a semi-quantitative dependency scale (1-4). Therefore, it is possible to incorporate this part of the assessment to the methodology at a later stage.

\subsubsection{Marine ecosystem services valuation methods}

Impacts on marine and coastal ecosystem services (ES) can either be valued by primary valuation methods or by value transfer (VT) methods. The VT methods use value information from existing studies or data in the literature to transfer to a relevant policy context in need of such information. VT methods are often used in practice, as there are frequently not sufficient time and/or resources to undertake new site-specific primary studies. These secondary valuation methods have in many contexts shown to be able to provide value estimates of ES of sufficient precision, but of course rely heavily on the availability of high-quality, relevant primary valuation studies to transfer values from (Johnston et al. 2015; Navrud and Ready 2007; Lindhjem and Navrud 2008). Appendix 11 provides a description of the main primary valuation techniques and the main requirements for performing valid VT.

\subsubsection{Ecosystem services and tradeoffs}

In many studies in which the purpose is to demonstrate or illustrate the benefits we receive from improved water status, it is not (so) important to consider the potential need for tradeoffs between different ecosystem services. In cost-benefit 
assessments however, including CBA for assessment of disproportionate costs, this may be of importance. There are four main types of tradeoffs considered central (Magnussen et al. 2013):

- Between ecosystem goods and services: Use and management of water resources may enhance one or a few services or use areas, at the expense of others.

- Over time: Management may give benefits in the short run, but negative impacts and costs at a later point in time. For management and use of natural resources the long-term perspective is normally of great importance.

- Between interest groups: Prioritizing of use areas which are important for some interest groups compared to others. If such tradeoffs have to be made, it may be that some groups mainly receive the benefits while others bear the costs.

- Spatial: Different kinds of regulations or management regimes may give benefits and costs that are spatially differentiated. These tradeoffs may be more or less inter-related. However, we will discuss each of them in turn.

Tradeoffs between different goods and services and over time are traditionally handled in welfare economic analysis while this is not the case for the latter two because these aspects are considered to be distributional/equity effects. However, these issues may be of great importance in practice, because they relate to who should pay for the improvements. In rivers, for example, the maximum benefits to society could be to reduce pollution in the water bodies upstream, because all the downstream water bodies then will reach improved water status. However, people living in the upstream water bodies may not receive so much of the benefits, while they may have to pay for most of the measures. The issue of tradeoffs is discussed further in Appendix 12.

\subsection{Practical application of the tool}

\subsubsection{A fictive example to illustrate the methodology}

A fictive case from the Baltic Sea is used to illustrate the steps in the methodology. Figure 3 below shows the fictive reference scenario where navigational routes south of Gotland pass close to and through the $\mathrm{N} 2000$ areas of North Middlebank and Hoburgs bank, both areas designated Important Bird Areas. South Middlebank, also designated Important Bird Areas (IBA), is found in the southern part of the area. 


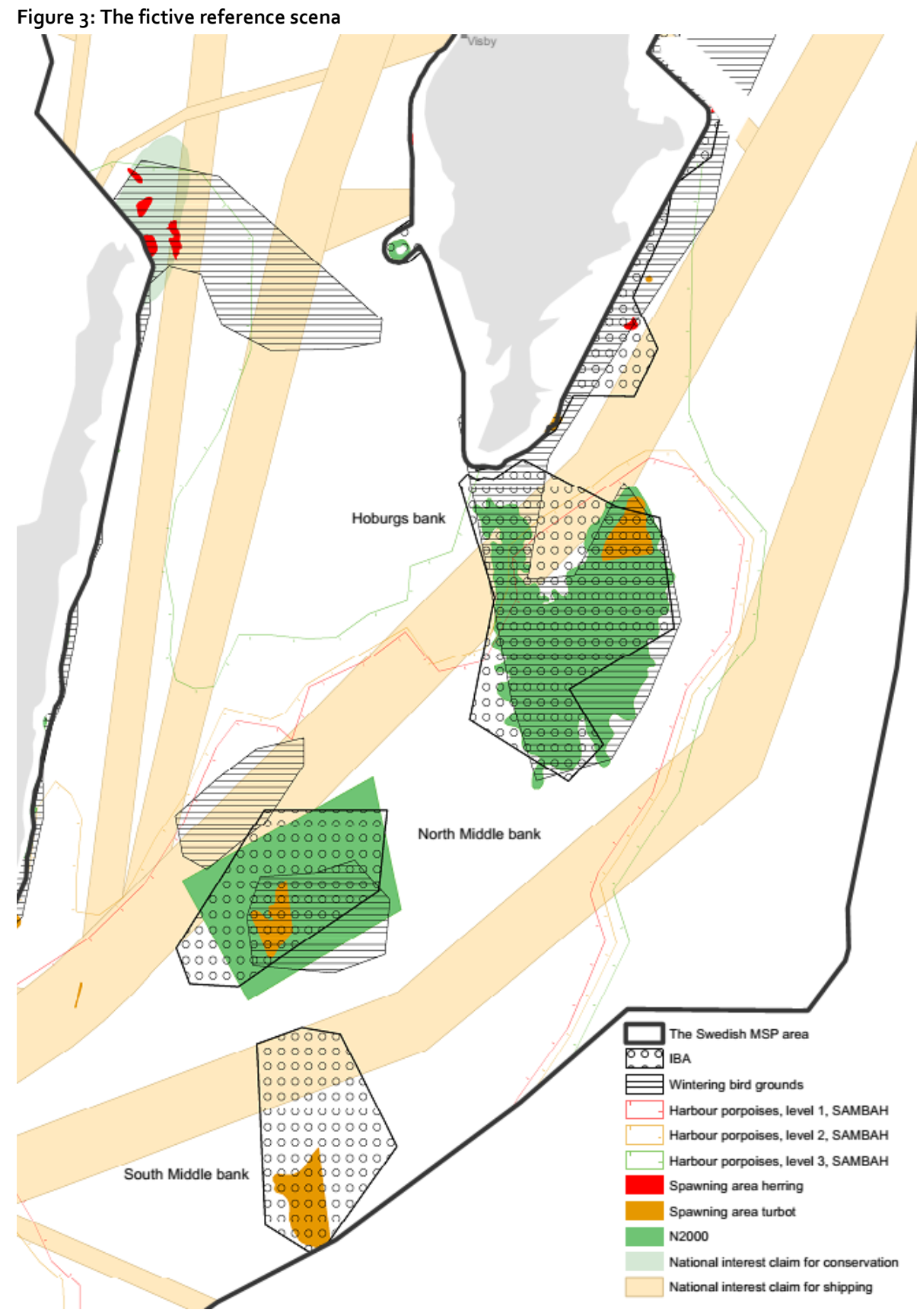

Note: The figure was provided by the Swedish Agency for Marine and Water Management (SwAM) in the preparations for the project workshop held at SwAM on the 5th of September 2016. 
Figure 4 below shows the fictive planned scenario where the navigational route just south of Gotland has been closed, the designated N2000 areas of Hoburgs bank and North Middlebank have been somewhat extended and connected, and an area for energy production has been designated at the South Middlebank.

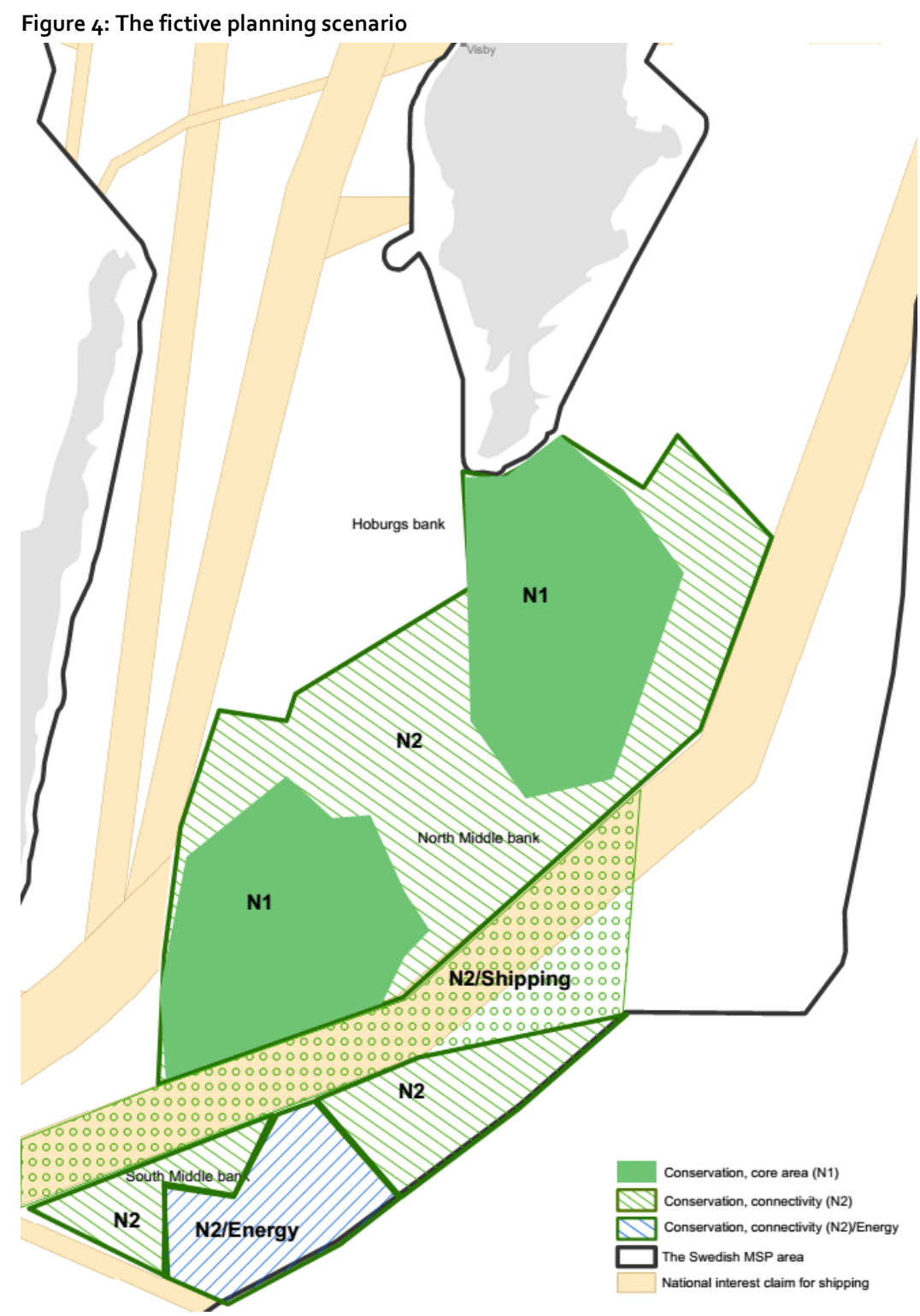

Note: The figure was provided by the Swedish Agency for Marine and Water Management (SwAM) in the preparations for the project workshop held at SwAM on the 5th of September 2016. 
The fictive scenarios described above will be used to illustrate how the methodology can be applied in evaluating the consequences for ecosystem service from a planning scenario. The actual impact assessments carried out in this example are only intended to illustrate the method and are not to be considered correct, worked through, assessments.

The general ideas behind each of the steps that are discussed in the sections below are followed by a practical application framed in green boxes. The practical application is based on the fictive example from the Baltic Sea presented above.

\subsubsection{Step 1. Scoping the analysis}

The first step implies setting geographical boundaries for the analysis and identifying and describing the relevant planning scenarios at hand. In addition to the geographical boundaries of the policy area, we also need to decide on the geographical scale for evaluating impacts on ecosystems and ecosystem services. The analysis may span between local, regional and global scales depending on what pressures and impacts

that are considered. The requested information could be deduced by answering the following questions:

- What planning scenario(s), or aspects of thereof, will be evaluated?

- What is the geographical boundary of the policy area?

- What is the relevant geographical scale for the analysis, i.e. at what scale should impacts on ecosystems and ecosystem services from the relevant activities be considered?

\subsubsection{What planning scenario(s), or aspects thereof, are we investigating?}

The most common case will revolve around analysis of proposed changes in the use of maritime space and resources in coastal or off-shore areas. It may in addition be relevant to analyse specific aspect of a new plan, e.g. what are the implications on recreational activities from extended aquaculture in a coastal area?

\subsubsection{What are the geographical boundaries of the policy area?}

The geographical area is generally designated in a plan-proposal and thus self-evident in most cases. In other cases, the plan area may need to be defined in accordance with specific needs, e.g. when only a part of the policy area is covered by the analysis e.g. due to a focus on a protected area or some other feature. 


\subsubsection{What is the relevant geographical scale for the analysis}

In addition to the geographical scale dictated by the extension of the policy area, a choice must be made regarding the analysis scale of changes in environmental pressure resulting from the proposed changes in maritime activities. These changes will in turn affect the provision and quality of ecosystem services with consequent economic impacts.

For instance; if spawning areas for commercial fish species are claimed in favour of wind mills, or extended navigational routes, the impacts in terms of decreased recruitment and fish yields need to be assessed in areas and locations relatively far away considered dependent on the habitats (ecosystem services) in the policy area.

Another example concerns climatic effects in terms of changes in the discharge of greenhouse gases due to local changes of maritime activities. These impacts will not be readily discernible on the local scale but need to be assessed in a global context.

\subsubsection{Practical application-Step 1. Scooping the analysis}

What planning scenario(s), or aspects thereof, are we investigating?

- We will investigate the consequences on ecosystem services from moving from the reference scenario to the planning scenario.

- The focus of the analysis will be on the possible conflict between the energy sector and the preservation of spawning areas (halibut) and wintering grounds for birds (N2000 areas), as well as marine transports passing through the area.

What are the geographical boundaries of the policy area?

The geographical boundaries of the policy area are given by the red square in Figure 5 below. 


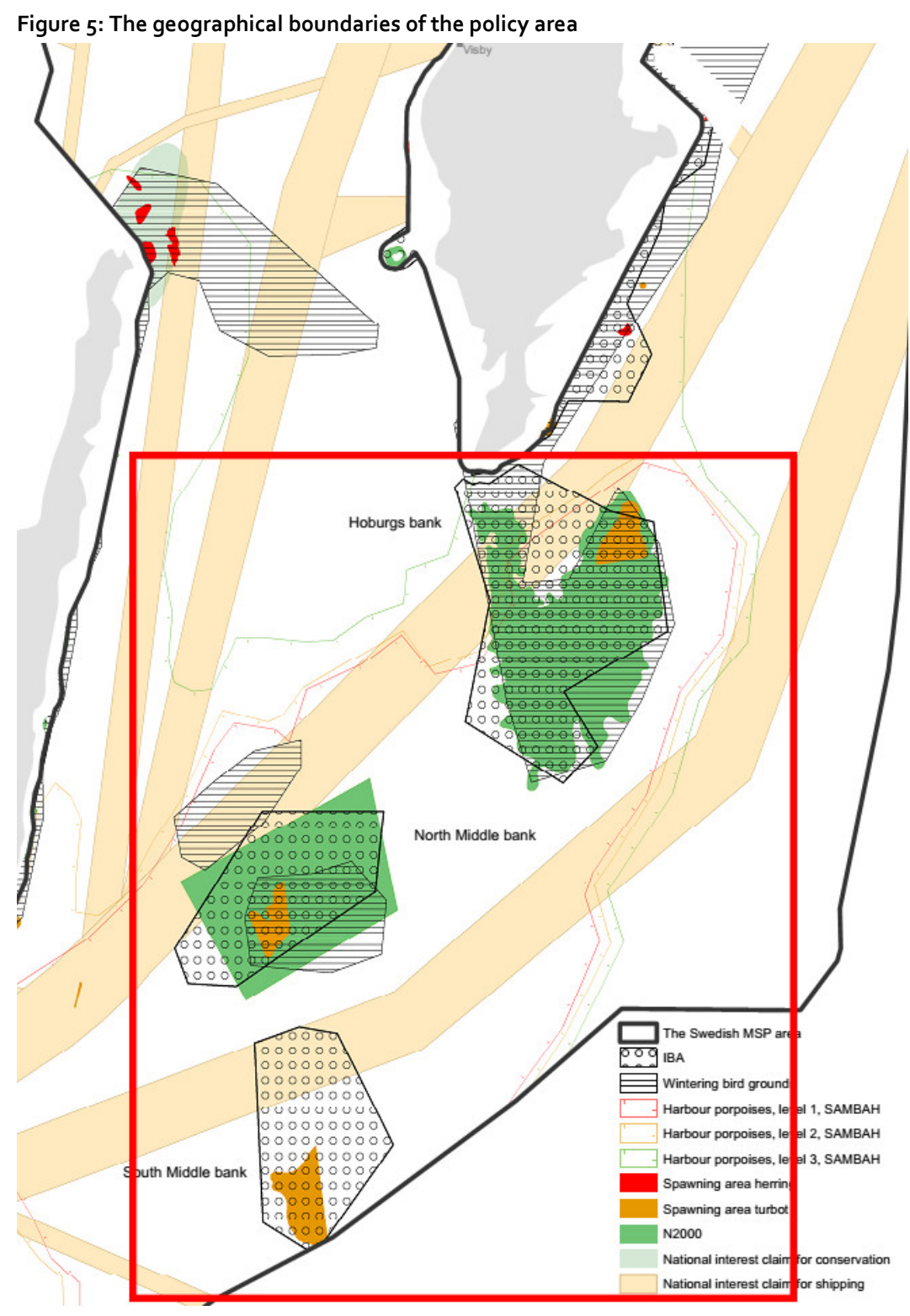

What is the relevant geographical scale for the analysis In this case, the scale for analysis coincides with the geographical delimitation as outlined in Figure 5 above. 


\subsubsection{Step 2. The reference scenario}

In the second step, a reference scenario is formulated consisting of:

- The marine activities that are currently carried out in the policy area.

- Associated environmental pressures.

- An assessment of the impact on ecosystem services.

In order to make an accurate description of a reference scenario, one also need to account for the changes in activities that might take place regardless of maritime spatial planning, i.e. scenarios of future development of the local maritime sectors, might be needed. At this stage, however, no temporal dimension is included in the analysis.

\subsubsection{Which activities are presently taking place in the policy area?}

A list of the relevant maritime activities is compiled, make use of the typology suggested in section 3.2. Information regarding the reference scenario is recorded systematically, when possible financial and social information, i.e. Economic significance and Number of jobs, are collected to underpin tradeoff and social analysis later in the process.

\subsubsection{What environmental pressures result from the ongoing activities?}

The environmental pressures that can be expected from the present maritime activities are listed with support from table 7 in section 3.2.

\subsubsection{What ecosystem services are impacted by which environmental pressures?}

Based on the list of identified environmental pressures compiled in the previous step, the impacts on ecosystem services are mapped using table 8 in section 3.3 (also in appendix 4).

\subsubsection{Assessment of the impact on ecosystem services in the reference scenario}

In the previous step, the ecosystem services potentially impacted by pressures resulting from ongoing maritime activities where identified (Table 11). In this step, the impacts from the pressures on the identified ecosystem services are either dismissed or confirmed. In the latter case, an assessment of the severity of the impact is done by 
making use of three criteria in a stepwise procedure, each criterion is in turn assessed by means of four-graded scales.

\subsubsection{Practical application-Step 2. The reference scenario}

Which activities are presently taking place in the policy area?

The maritime sector activities currently undertaken in the reference scenario are listed along with information on spatial claim, economic significance and if available, number of associated jobs.

Table 9: Ongoing maritime activities in the reference scenario

$\begin{array}{llll}\text { Ongoing activity } & \text { Spatial claim }\left(\mathrm{m}^{2}, \mathrm{~km}^{2}, \mathrm{ha}, \%\right) & \text { Economic significance } & \text { Number of associated jobs } \\ \text { Marine transports. } & 6,000 \mathrm{~km}^{2} & \begin{array}{l}20,000 \text { (northern route) }+ \\ 10,000 \text { (southern route) } \\ \text { ships per year passing } \\ \text { through the area. }\end{array} \\ & & \\ & & \\ & \end{array}$

What environmental pressures result from the ongoing activities?

By making use of Table 7 in section 3.2, the following pressures have been linked to the maritime activity marine transport, see Table 10 below.

Table 10: Environmental pressures linked to shipping

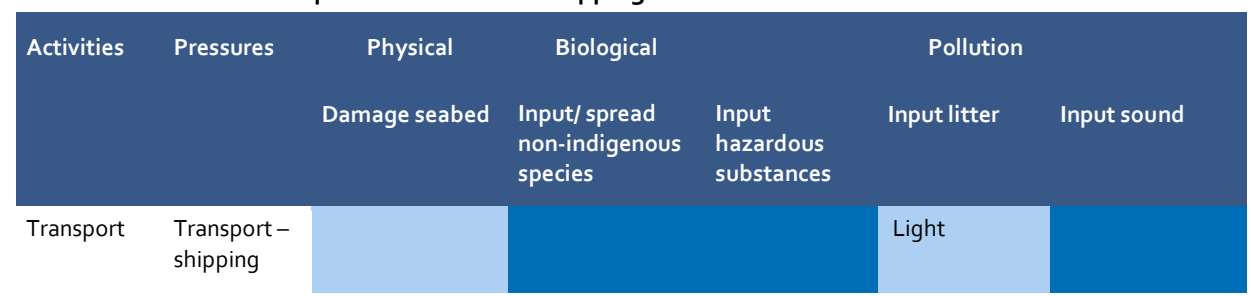

Note: The dark (greater pressure) and light (lesser pressure) cells act only as a very general guide as to the relative importance of each pressure for each activity

What ecosystem services are impacted by which environmental pressures?

The environmental pressures from marine transports identified in the previous step are used to identify the affected ecosystem services by making use of Table 8 in section 3.3. The original list of pressures is thus shortened and covers only the pressures relevant in the policy area, see Table 11. 
Table 11: Ecosystem services affected by the identified environmental pressures

\begin{tabular}{|c|c|c|c|c|c|c|c|c|c|c|c|c|c|c|c|c|c|c|c|c|c|c|c|}
\hline \multirow[b]{4}{*}{ Pressure } & \multirow[b]{4}{*}{$\begin{array}{l}\text { Pressure } \\
\text { theme }\end{array}$} & \multicolumn{22}{|c|}{ Ecosystem services } \\
\hline & & \multirow{3}{*}{$\begin{array}{l}\text { P1 } \\
\text { Sea } \\
\text { food }\end{array}$} & \multicolumn{5}{|c|}{ Provisioning } & \multirow{3}{*}{$\begin{array}{l}\text { R1 } \\
\text { Air } \\
\text { purify- } \\
\text { cation }\end{array}$} & \multirow{3}{*}{$\begin{array}{l}\text { R2 } \\
\text { Climate } \\
\text { regu- } \\
\text { lation }\end{array}$} & \multirow{3}{*}{$\begin{array}{l}\text { R3 } \\
\text { Disturb } \\
\text { ance } \\
\text { prevent } \\
\text { ion or } \\
\text { regu- } \\
\text { lation }\end{array}$} & \multicolumn{3}{|c|}{ Regulating services } & \multirow[b]{2}{*}{$\mathrm{R}_{7}$} & \multirow{3}{*}{$\begin{array}{l}\text { R8 } \\
\text { Biologi } \\
\text { cal } \\
\text { control }\end{array}$} & \multicolumn{2}{|c|}{$\begin{array}{l}\text { Habitat services } \\
\text { (Regulating) }\end{array}$} & \multirow[b]{2}{*}{$\mathrm{C}_{1}$} & \multirow{3}{*}{$\begin{array}{l}\text { C2 } \\
\text { Inspira- } \\
\text { tion } \\
\text { and } \\
\text { Culture } \\
\text { Art/ } \\
\text { Design }\end{array}$} & \multicolumn{2}{|c|}{ Cultural service } & \multirow[b]{3}{*}{$\begin{array}{l}\mathrm{C}_{5} \\
\text { Infor- } \\
\text { mation } \\
\text { for } \\
\text { cogni- } \\
\text { tive } \\
\text { deve- } \\
\text { lop- } \\
\text { ment }\end{array}$} & \multirow{3}{*}{$\begin{array}{l}\text { C6 } \\
\text { Spiritu- } \\
\text { al } \\
\text { Exper- } \\
\text { ience }\end{array}$} \\
\hline & & & $\mathbf{P}_{2}$ & $P_{3}$ & $P_{4}$ & $P_{5}$ & P6 & & & & $\mathbf{R}_{4}$ & $\mathrm{R}_{5}$ & R6 & & & $\mathrm{H}_{1}$ & $\mathrm{H}_{2}$ & & & $C_{3}$ & $\mathrm{C}_{4}$ & & \\
\hline & & & $\begin{array}{l}\text { Sea } \\
\text { water }\end{array}$ & $\begin{array}{l}\text { Raw } \\
\text { mater- } \\
\text { ial }\end{array}$ & $\begin{array}{l}\text { Genetic } \\
\text { re- } \\
\text { sources } \\
\text { (DNA) }\end{array}$ & $\begin{array}{l}\text { Medi- } \\
\text { cinal } \\
\text { re- } \\
\text { sources }\end{array}$ & $\begin{array}{l}\text { Orna- } \\
\text { mental } \\
\text { re- } \\
\text { sources }\end{array}$ & & & & $\begin{array}{l}\text { Regu- } \\
\text { latin of } \\
\text { water } \\
\text { flows }\end{array}$ & $\begin{array}{l}\text { Nu- } \\
\text { trient } \\
\text { regula- } \\
\text { tion }\end{array}$ & $\begin{array}{l}\text { Waste } \\
\text { treat- } \\
\text { ment }\end{array}$ & $\begin{array}{l}\text { Coastal } \\
\text { erosion } \\
\text { preven- } \\
\text { tion }\end{array}$ & & $\begin{array}{l}\text { Life- } \\
\text { cycle } \\
\text { mainte } \\
\text { nace }\end{array}$ & $\begin{array}{l}\text { Gene } \\
\text { pool } \\
\text { protect } \\
\text { ion }\end{array}$ & $\begin{array}{l}\text { Recre- } \\
\text { ation } \\
\text { and } \\
\text { leisure }\end{array}$ & & $\begin{array}{l}\text { Cultu- } \\
\text { ral } \\
\text { heritag } \\
\text { e and } \\
\text { identi- } \\
\text { ty }\end{array}$ & $\begin{array}{l}\text { Aesthe } \\
\text { tic } \\
\text { infor- } \\
\text { matoin } \\
\text { /Land- } \\
\text { scape }\end{array}$ & & \\
\hline Physical & $\begin{array}{l}\text { Damage } \\
\text { seabed }\end{array}$ & & & & & & & & & & & & & & & & & & & & & & \\
\hline Biological & $\begin{array}{l}\text { Input/ } \\
\text { spread non- } \\
\text { indigenous } \\
\text { species }\end{array}$ & & & & & & & & & & & & & & & & & & & & & & \\
\hline Pollution & $\begin{array}{l}\text { Input } \\
\text { hazardous } \\
\text { substances }\end{array}$ & & & & & & & & & & & & & & & & & & & & & & \\
\hline & Input litter & & & & & & & & & & & & & & & & & & & & & & \\
\hline & Input sound & & & & & & & & & & & & & & & & & & & & & & \\
\hline
\end{tabular}


Assessment of the impact on ecosystem services in the reference scenario In the previous step, the ecosystem services potentially impacted by pressures resulting from ongoing maritime activities where identified (Table 11). In this step, the impacts from the pressures on the identified ecosystem services are either dismissed or confirmed. In the latter case, an assessment of the severity of the impact is done by making use of three criteria in a stepwise procedure, each criterion is in turn assessed by means of four-graded scales. The three criteria are:

- "How large is the impacted area?"

- "How severe is the impact in the area affected?"

- "Are the damages resulting from the impact reversible once they have occurred?"

Table 12: Criteria for deciding the size of the overall impact on an ecosystem service from a maritime activity

\begin{tabular}{|c|c|c|c|c|c|c|}
\hline Criteria & & able sc & ore lev & $\begin{array}{r}\text { vels, see } \\
\text { above }\end{array}$ & $\begin{array}{l}\text { Assessment (scores, } 1-4 \text {, filled in } \\
\text { by the user) }\end{array}$ & \\
\hline Size of impacted area & 1 & 2 & 3 & 4 & & 3-4 Low \\
\hline Severity of impact & 1 & 2 & 3 & 4 & & 5-7 Medium \\
\hline Irreversibility of damage & 1 & 2 & 3 & 4 & & 8-10 High \\
\hline \multicolumn{6}{|c|}{ Overall impact score ([criteria 1-3) } & 11-12 Very high \\
\hline
\end{tabular}

A detailed description of the scores themselves, and how they area aggregated is given in Appendix 10.

The result from the analysis, i.e. the impact assessment of each pressure (and associated activity), are recorded and summarized in table A4.1, see Appendix 4. There are several maritime sectors/activities that give rise to similar environmental pressures. This is considered in Table A4.1 where more than one activity may be linked to each pressure, add as many rows as needed for each pressure based on the number of impacting activities.

The same activity may occur on several lines in Table A4.1 as it may cause several different environmental pressures at the same time. This implies that one specific activity may impact the same ecosystem service in several ways. Table A5.1 (Appendix 5 ) may be used to compile the overall impact on ecosystem services from each specific activity by summing the recorded scores from Table $\mathrm{A}_{4.1} 1$ for each affected ecosystem service. 
The following pressures were identified as relevant with regards to ongoing activities, i.e. Transport-shipping (Table 10):

- Physical-Damage seabed.

- Biological - Input/Spread non-indigenous species.

- Pollution - Input hazardous substances.

- Pollution - Input marine litter.

- Pollution - Input sound.

Below follows an example of the arguments and reasoning that might be used by experts when assessing individual impact criterion from ongoing maritime activities, i.e. Transport-shipping. The assessment starts with the pressure Physical - Damage Seabed. Each of the ecosystem services that have been linked to the pressure (Table 11) are assessed from an impact point of view and the assigned scores are summarized in Table 13 below. For the remaining pressures, only the scores are presented and the arguments are left out.

Physical - Damage seabed; Transport shipping

\section{P1 Sea Food}

1. How large is the impacted area?

Potential damage to the seabed is restricted to the areas covered by the shipping routes passing through the area, the area affected is assessed to be between 10$15 \%$ - the score 2 is assigned.

2. How severe is the impact in the area affected?

Seabed damages from shipping are primarily inflicted by erosion from propeller currents or waves, or by abrasion due to anchoring. Neither of these effects are considered to be of importance in the area due to water depth and distance from harbors - the score 1 is assigned.

3. Is the level of damage to ecosystem services from the impact irreversible once they have occurred?

If damage occurs, it is considered easily repaired - the score 1 is assigned.

\section{$\mathrm{P}_{3}$ Genetic resources (DNA)}

The threat to genetic resources are primarily linked to the input of non-indigenous species through release of ballast water, this is considered irrelevant in this area for two reasons; 1) the area is located far from the nearest port which makes it unlikely for any ship to 
empty any ballast water, 2) the convention on ballast water prevents uncontrolled release of ballast water. The impact on the ecosystem service is therefore dismissed which is indicated by a diagonal line through the relevant box in the table below.

\section{R6 Waste treatment}

1. How large is the impacted area?

If the seafloor in the area is impacted by input of e.g. organic matter or pollutants affecting the ecosystem service, the impacted area is considered to be high, between $70-100 \%$ - the score 3 is assigned.

2. How severe is the impact in the area affected?

The severity of the impact from shipping is however considered to be low - the score 1 is assigned.

3. Is the level of damage to ecosystem services from the impact irreversible once they have occurred?

If damage occurs, it is considered easily repaired - the score 1 is assigned.

R7 Coastal erosion prevention

1. How large is the impacted area?

It is only the northern part of the area, the southern shores of Gotland close to the navigational route, that might be of relevance for this pressure. The area affected is relatively small (1-10\%) - the score 1 is assigned.

2. How severe is the impact in the area affected?

The distance from the navigational route to the shallow areas are considered to be long enough to dissipate most of the energy residing in waves originating from the ships, hence the severity of the impact is considered to be low - the score 1 is assigned.

3. Is the level of damage to ecosystem services from the impact irreversible once they have occurred?

If damage occurs, it is considered easily repaired - the score 1 is assigned.

R8 Biological control

The impact on this ecosystem service is better described under the ecosystem service Lifecycle maintenance, it is therefore dismissed from the analysis and the relevant box is marked with a diagonal line in the table below. 


\section{H1 Lifecycle maintenance}

1. How large is the impacted area?

Potential damage to the seabed is restricted to the areas covered by the shipping routes passing through the area, the area affected is assessed to be between 10$15 \%$ - the score 2 is assigned.

2. How severe is the impact in the area affected?

The severity of the impact from shipping (disturbance (due to e.g. anchoring) of habitats of importance for recruitment of commercial fish species and for the support of wintering birds) is however considered to be low - the score 1 is assigned.

3. Is the level of damage to ecosystem services from the impact irreversible once they have occurred?

If damage occurs, it is considered easily repaired - the score 1 is assigned.

\section{$\mathrm{H} 2$ Gene pool protection}

This ecosystem service is dismissed for the same reasons as discussed under the ecosystem service $\mathrm{P}_{3}$ Genetic resources (DNA). The relevant box is marked with a diagonal line in the table below.

\section{C1 Recreation and leisure}

Impact on this ecosystem service, due to damages on the seabed as a result from shipping, is dismissed from the analysis. The reason is that the effect will potentially only be of importance with regards to scuba diving, an activity not relevant in the shipping lane. The relevant box is marked with a diagonal line in the table below.

\section{$\mathrm{C}_{3}$ Cultural heritage and identity}

Impact on this ecosystem service, due to damages on the seabed as a result from shipping, is dismissed from the analysis since the impact with potential repercussions on e.g. cultural traditions and folklore is considered to be insignificant. The relevant box is marked with a diagonal line in the table below.

\section{C4 Aesthetic information/Landscape}

1. How large is the impacted area?

Potential damage to the seabed is restricted to the areas covered by the shipping routes passing through the area, the area affected is assessed to be between 10$15 \%$ - the score 2 is assigned. 
2. How severe is the impact in the area affected?

The severity of the impact from shipping (disturbance (due to e.g. anchoring) of

characteristic habitats of the banks) is however considered to be low - the score 1 is

assigned.

3. Is the level of damage to ecosystem services from the impact irreversible once they have occurred?

If damage occurs, it is considered easily repaired - the score 1 is assigned.

Table 13: Pressure; Damage seabed

\begin{tabular}{|c|c|c|c|c|c|c|c|c|c|c|c|c|}
\hline & $P_{1}$ & $\mathbf{P}_{2}$ & $P_{3}$ & $\mathrm{P}_{4}$ & R6 & R7 & R8 & $\mathrm{H}_{1}$ & $\mathrm{H}_{2}$ & $C_{1}$ & $C_{3}$ & $\mathrm{C}_{4}$ \\
\hline $\begin{array}{l}\text { Pressure; } \\
\text { Damage } \\
\text { seabed }\end{array}$ & $\begin{array}{l}\text { Sea } \\
\text { food }\end{array}$ & $\begin{array}{l}\text { Sea } \\
\text { water }\end{array}$ & $\begin{array}{l}\text { Raw } \\
\text { mater- } \\
\text { ial }\end{array}$ & $\begin{array}{l}\text { Genetic } \\
\text { re- } \\
\text { sources } \\
\text { (DNA) }\end{array}$ & $\begin{array}{l}\text { Waste } \\
\text { treat- } \\
\text { ment }\end{array}$ & $\begin{array}{l}\text { Coas- } \\
\text { tal ero- } \\
\text { sion } \\
\text { preven- } \\
\text { tion }\end{array}$ & $\begin{array}{l}\text { Biolo- } \\
\text { gical } \\
\text { con- } \\
\text { trol }\end{array}$ & $\begin{array}{l}\text { Life- } \\
\text { cycle } \\
\text { main- } \\
\text { tenace }\end{array}$ & $\begin{array}{l}\text { Gene } \\
\text { pool } \\
\text { protec- } \\
\text { tion }\end{array}$ & $\begin{array}{l}\text { Recre- } \\
\text { ation } \\
\text { and } \\
\text { leisure }\end{array}$ & $\begin{array}{l}\text { Cul-tural } \\
\text { her- } \\
\text { itage } \\
\text { and } \\
\text { identity }\end{array}$ & $\begin{array}{l}\text { Aesthetic } \\
\text { informa- } \\
\text { tion/ } \\
\text { Landscape }\end{array}$ \\
\hline Size & 2 & & & & 3 & 1 & & 2 & & & & 2 \\
\hline Severity & 1 & & & & 1 & 1 & & 1 & & & & 1 \\
\hline Irreversibility & 1 & & & & 1 & 1 & & 1 & & & & 1 \\
\hline $\begin{array}{l}\text { Overall impact } \\
\text { score ( } \sum \text { criteria } \\
1-3)\end{array}$ & 4 & & & & 5 & 3 & & 4 & & & & 4 \\
\hline
\end{tabular}

The procedure is repeated for all the environmental pressures identified as relevant, see above. The results in the tables below are based on the same kind of reasoning applied for the pressure Damage seabed.

Table 14: Biological - Input/Spread non-indigenous species; Transport shipping

\begin{tabular}{|c|c|c|c|c|c|c|c|c|c|c|c|c|}
\hline $\begin{array}{l}\text { Pressure; } \\
\text { Biological - } \\
\text { Input/Spread } \\
\text { non-indigenous } \\
\text { species }\end{array}$ & $\begin{array}{l}\text { P1 } \\
\text { Sea } \\
\text { food }\end{array}$ & $\begin{array}{l}\text { P2 } \\
\text { Sea } \\
\text { water }\end{array}$ & $\begin{array}{l}\mathrm{P}_{3} \\
\text { Raw } \\
\text { mate- } \\
\text { rial }\end{array}$ & $\begin{array}{l}\mathrm{P}_{4} \\
\text { Gene- } \\
\text { tic re- } \\
\text { sources } \\
\text { (DNA) }\end{array}$ & $\begin{array}{l}\text { R6 } \\
\text { Waste } \\
\text { treat- } \\
\text { ment }\end{array}$ & $\begin{array}{l}\text { R7 } \\
\text { Coast- } \\
\text { al } \\
\text { erosion } \\
\text { preven- } \\
\text { tion }\end{array}$ & $\begin{array}{l}\text { R8 } \\
\text { Biologi- } \\
\text { cal } \\
\text { control }\end{array}$ & $\begin{array}{l}\mathrm{H} 1 \\
\text { Life- } \\
\text { cycle } \\
\text { main- } \\
\text { tenace }\end{array}$ & $\begin{array}{l}\mathrm{H}_{2} \\
\text { Gene } \\
\text { pool } \\
\text { protec- } \\
\text { tion }\end{array}$ & $\begin{array}{l}\text { C1 } \\
\text { Recrea- } \\
\text { tion } \\
\text { and } \\
\text { leisure }\end{array}$ & $\begin{array}{l}C_{3} \\
\text { Cultural } \\
\text { heritage } \\
\text { and } \\
\text { identity }\end{array}$ & $\begin{array}{l}\mathrm{C}_{4} \\
\text { Aesthe- } \\
\text { tic } \\
\text { informa- } \\
\text { tion/ } \\
\text { Land- } \\
\text { scape }\end{array}$ \\
\hline & & & & & & & & & & & & \\
\hline Size & 2 & & & 4 & & & & 2 & 2 & & & \\
\hline Severity & 2 & & & 3 & & & & 3 & 3 & & & \\
\hline Irreversibility & 4 & & & 4 & & & & 4 & 4 & & & \\
\hline $\begin{array}{l}\text { Overall impact } \\
\text { score ( } \sum \text { criteria } \\
1-3)\end{array}$ & 8 & & & 11 & & & & 9 & 9 & & & \\
\hline
\end{tabular}


Table 15: Pollution - Input hazardous substances; Transport shipping

\begin{tabular}{|c|c|c|c|c|c|c|c|c|c|c|c|c|}
\hline & $\mathrm{P}_{1}$ & $\mathbf{P}_{2}$ & $P_{3}$ & $P_{4}$ & R6 & R7 & $\mathbf{R 8}$ & $\mathrm{H}_{\mathbf{1}}$ & $\mathrm{H}_{2}$ & $\mathrm{C}_{1}$ & $\mathrm{C}_{3}$ & $C_{4}$ \\
\hline $\begin{array}{l}\text { Pressure; } \\
\text { Biological - } \\
\text { Input/ Spread } \\
\text { non-indigenous } \\
\text { species }\end{array}$ & $\begin{array}{l}\text { Sea } \\
\text { food }\end{array}$ & $\begin{array}{l}\text { Sea } \\
\text { water }\end{array}$ & $\begin{array}{l}\text { Raw } \\
\text { mate } \\
\text {-rial }\end{array}$ & $\begin{array}{l}\text { Gene- } \\
\text { tic re- } \\
\text { sources } \\
\text { (DNA) }\end{array}$ & $\begin{array}{l}\text { Waste } \\
\text { treat- } \\
\text { ment }\end{array}$ & $\begin{array}{l}\text { Coast- } \\
\text { al } \\
\text { ero- } \\
\text { sion } \\
\text { pre- } \\
\text { ven- } \\
\text { tion }\end{array}$ & $\begin{array}{l}\text { Bio- } \\
\text { logi- } \\
\text { cal } \\
\text { con- } \\
\text { trol }\end{array}$ & $\begin{array}{l}\text { Life- } \\
\text { cycle } \\
\text { main- } \\
\text { tenace }\end{array}$ & $\begin{array}{l}\text { Gene } \\
\text { pool } \\
\text { pro- } \\
\text { tec- } \\
\text { tion }\end{array}$ & $\begin{array}{l}\text { Re- } \\
\text { crea- } \\
\text { tion } \\
\text { and } \\
\text { leisure }\end{array}$ & $\begin{array}{l}\text { Cultur } \\
\text { al } \\
\text { heri- } \\
\text { tage } \\
\text { and } \\
\text { iden- } \\
\text { tity }\end{array}$ & $\begin{array}{l}\text { Aest- } \\
\text { hetic } \\
\text { informa- } \\
\text { tion/ } \\
\text { Land- } \\
\text { scape }\end{array}$ \\
\hline Size & 4 & & & & 4 & & & 3 & 3 & & & \\
\hline Severity & 2 & & & & 2 & & & 3 & 3 & & & \\
\hline Irreversibility & 2 & & & & 2 & & & 2 & 2 & & & \\
\hline $\begin{array}{l}\text { Overall impact } \\
\text { score ( } \sum \text { criteria } \\
1-3)\end{array}$ & 8 & & & & 8 & & & 8 & 8 & & & \\
\hline
\end{tabular}

Table 16: Pollution - Input marine litter; Transport shipping

\begin{tabular}{|c|c|c|c|c|c|c|c|c|c|c|c|c|}
\hline $\begin{array}{l}\text { Pressure; } \\
\text { Biological - } \\
\text { Input/Spread } \\
\text { non-indigenous } \\
\text { species }\end{array}$ & $\begin{array}{l}\text { P1 } \\
\text { Sea } \\
\text { food }\end{array}$ & $\begin{array}{l}\text { P2 } \\
\text { Sea } \\
\text { water }\end{array}$ & $\begin{array}{l}\mathrm{P}_{3} \\
\text { Raw } \\
\text { mate } \\
\text {-rial }\end{array}$ & $\begin{array}{l}\mathrm{P}_{4} \\
\text { Gene- } \\
\text { tic re- } \\
\text { sources } \\
\text { (DNA) }\end{array}$ & $\begin{array}{l}\text { R6 } \\
\text { Waste } \\
\text { treat- } \\
\text { ment }\end{array}$ & $\begin{array}{l}\text { R7 } \\
\text { Coast } \\
\text {-al } \\
\text { ero- } \\
\text { sion } \\
\text { pre- } \\
\text { ven- } \\
\text { tion }\end{array}$ & $\begin{array}{l}\text { R8 } \\
\text { Bio- } \\
\text { logi- } \\
\text { cal } \\
\text { con- } \\
\text { trol }\end{array}$ & $\begin{array}{l}\mathrm{H}_{1} \\
\text { Life- } \\
\text { cycle } \\
\text { main- } \\
\text { tenace }\end{array}$ & $\begin{array}{l}\mathrm{H}_{2} \\
\text { Gene } \\
\text { pool } \\
\text { pro- } \\
\text { tec- } \\
\text { tion }\end{array}$ & $\begin{array}{l}\text { C1 } \\
\text { Re- } \\
\text { crea- } \\
\text { tion } \\
\text { and } \\
\text { leisure }\end{array}$ & $\begin{array}{l}\mathrm{C}_{3} \\
\text { Cultur } \\
\text { al } \\
\text { heri- } \\
\text { tage } \\
\text { and } \\
\text { iden- } \\
\text { tity }\end{array}$ & $\begin{array}{l}\mathrm{C}_{4} \\
\text { Aest- } \\
\text { hetic } \\
\text { informa- } \\
\text { tion/ } \\
\text { Land- } \\
\text { scape }\end{array}$ \\
\hline & & & & & & & & & & & & \\
\hline Size & 2 & & & & & & & 2 & & 4 & & 4 \\
\hline Severity & 2 & & & & & & & 2 & & 1 & & 1 \\
\hline Irreversibility & 1 & & & & & & & 1 & & 1 & & 1 \\
\hline $\begin{array}{l}\text { Overall impact } \\
\text { score ( } \sum \text { criteria } \\
1-3)\end{array}$ & 5 & & & & & & & 5 & & 6 & & 6 \\
\hline
\end{tabular}


Table 17: Pollution - Input sound; Transport shipping

\begin{tabular}{|c|c|c|c|c|c|c|c|c|c|c|c|c|}
\hline $\begin{array}{l}\text { Pressure; } \\
\text { Biological - } \\
\text { Input/Spread } \\
\text { non-indigenous } \\
\text { species }\end{array}$ & $\begin{array}{l}P_{1} \\
\text { Sea } \\
\text { food }\end{array}$ & $\begin{array}{l}P_{2} \\
\text { Sea } \\
\text { water }\end{array}$ & $\begin{array}{l}\mathrm{P}_{3} \\
\text { Raw } \\
\text { mate- } \\
\text { rial }\end{array}$ & $\begin{array}{l}\mathrm{P}_{4} \\
\text { Gene- } \\
\text { tic re- } \\
\text { sources } \\
\text { (DNA) }\end{array}$ & $\begin{array}{l}\text { R6 } \\
\text { Waste } \\
\text { treat- } \\
\text { ment }\end{array}$ & $\begin{array}{l}\text { R7 } \\
\text { Coast- } \\
\text { al } \\
\text { ero- } \\
\text { sion } \\
\text { pre- } \\
\text { ven- } \\
\text { tion }\end{array}$ & $\begin{array}{l}\text { R8 } \\
\text { Bio- } \\
\text { logi- } \\
\text { cal } \\
\text { con- } \\
\text { trol }\end{array}$ & $\begin{array}{l}\text { H1 } \\
\text { Life- } \\
\text { cycle } \\
\text { main- } \\
\text { tenace }\end{array}$ & $\begin{array}{l}\mathrm{H}_{2} \\
\text { Gene } \\
\text { pool } \\
\text { pro- } \\
\text { tec- } \\
\text { tion }\end{array}$ & $\begin{array}{l}\text { C1 } \\
\text { Re- } \\
\text { crea- } \\
\text { tion } \\
\text { and } \\
\text { leisure }\end{array}$ & $\begin{array}{l}\mathrm{C}_{3} \\
\text { Cultura } \\
\text { Iheri- } \\
\text { tage } \\
\text { and } \\
\text { iden- } \\
\text { tity }\end{array}$ & $\begin{array}{l}\mathrm{C}_{4} \\
\text { Aest- } \\
\text { hetic } \\
\text { inform } \\
\text { a-tion/ } \\
\text { Land- } \\
\text { scape }\end{array}$ \\
\hline \multicolumn{13}{|l|}{ Size } \\
\hline \multicolumn{13}{|l|}{ Severity } \\
\hline Irreversibility & & & & & & & & & & & & \\
\hline $\begin{array}{l}\text { Overall impact } \\
\text { score ( }(\text { criteria } \\
1-3)\end{array}$ & & & & & & & & & & & & \\
\hline
\end{tabular}

The results from the impact assessments in the reference alternative are compiled in table 18 below. 
Table 18: The impact scores in the reference scenario are compiled and presented

\begin{tabular}{|c|c|c|c|c|c|c|c|c|c|c|c|c|c|c|c|}
\hline & & & \multicolumn{12}{|c|}{ Ecosystem services } & \multirow[b]{4}{*}{$\begin{array}{l}\text { Impact score per } \\
\text { pressure and } \\
\text { activity }(\Sigma)\end{array}$} \\
\hline & & & \multicolumn{4}{|c|}{ Provisioning services } & \multicolumn{3}{|c|}{ Regulating services } & \multicolumn{2}{|c|}{$\begin{array}{c}\text { Habitat services (Regula- } \\
\text { ting) }\end{array}$} & \multicolumn{3}{|c|}{ Cultural services } & \\
\hline & & & $\mathrm{P}_{1}$ & $\mathrm{P}_{2}$ & $P_{3}$ & $\mathrm{P}_{4}$ & R6 & R7 & R8 & $\mathrm{H}_{1}$ & $\mathrm{H}_{2}$ & $\mathrm{C}_{1}$ & $c_{3}$ & $C_{4}$ & \\
\hline Pressure & $\begin{array}{l}\text { Pressure } \\
\text { theme }\end{array}$ & Activities & Sea food & $\begin{array}{l}\text { Sea } \\
\text { water }\end{array}$ & $\begin{array}{l}\text { Raw } \\
\text { material }\end{array}$ & $\begin{array}{l}\text { Genetic } \\
\text { resources } \\
\text { (DNA) }\end{array}$ & $\begin{array}{l}\text { Waste } \\
\text { treatment }\end{array}$ & $\begin{array}{l}\text { Coastal } \\
\text { erosion } \\
\text { prevention }\end{array}$ & $\begin{array}{l}\text { Biological } \\
\text { control }\end{array}$ & $\begin{array}{l}\text { Lifecycle } \\
\text { maintenace }\end{array}$ & $\begin{array}{l}\text { Gene pool } \\
\text { protection }\end{array}$ & $\begin{array}{l}\text { Recreation } \\
\text { and leisure }\end{array}$ & $\begin{array}{l}\text { Cultural } \\
\text { heritage and } \\
\text { identity }\end{array}$ & $\begin{array}{l}\text { Aesthetic } \\
\text { information/ } \\
\text { Landscape }\end{array}$ & \\
\hline \multicolumn{16}{|l|}{ Physical } \\
\hline & $\begin{array}{l}\text { Damaged } \\
\text { seabed }\end{array}$ & $\begin{array}{l}\text { Transport- } \\
\text { shipping }\end{array}$ & 4 & & & & 5 & 3 & & 4 & & & & 4 & 20 \\
\hline \multicolumn{16}{|l|}{ Biological } \\
\hline & $\begin{array}{l}\text { Change } \\
\text { hydrology }\end{array}$ & $\begin{array}{l}\text { Transport- } \\
\text { shipping }\end{array}$ & 8 & & & .11 & & & & 9 & 9 & & & & 37 \\
\hline \multicolumn{16}{|l|}{ Pollution } \\
\hline & $\begin{array}{l}\text { Input } \\
\text { hazardous } \\
\text { substances }\end{array}$ & $\begin{array}{l}\text { Transport- } \\
\text { shipping }\end{array}$ & 8 & & & & 8 & & & 8 & 8 & & & & 32 \\
\hline & & $\begin{array}{l}\text { Transport- } \\
\text { shipping }\end{array}$ & 5 & & & & & & & 5 & & 6 & & 6 & 22 \\
\hline & Input litter & $\begin{array}{l}\text { Transport- } \\
\text { shipping }\end{array}$ & & & & & & & & & & & & & \\
\hline & Input sound & & & 11 & 13 & 3 & & 26 & 17 & 6 & & 10 & & & \\
\hline
\end{tabular}




\subsubsection{Step 3. Identification and description of (a) planning scenario(s)}

The third step involves identification and description of one or several relevant planning scenarios. This includes the planned changes in maritime activities, the resulting impact on ecosystems and associated ecosystem services, the dependency on ecosystems of the relevant activities, and finally the impact on other maritime activities not directly subjected to planning. The requested information for step 3 corresponds to the information gathered for the reference scenario, but this time it covers the planning scenario:

- The marine/maritime activities that are planned for the policy area.

- Associated environmental pressures.

- Assessment of the impact on ecosystem services assessment of dependencies on ecosystem services of the relevant maritime activities.

\subsubsection{Which activities are planned for the policy area?}

A list of the relevant maritime activities is compiled, make use of the typology suggested in section 3.2 with associated environmental pressures described in Table 7.

As for the reference scenario, information regarding the planned scenario is recorded systematically, when possible financial and social information, i.e. Economic significance and Number of jobs, are collected to underpin tradeoff and social analysis later in the process.

\subsubsection{What environmental pressures result from the planned activities?}

The environmental pressures that can be expected from the planned maritime activities are listed with support from the typology presented in section 3.2.

\subsubsection{What ecosystem services are impacted by which environmental pressures?}

Based on the list of identified environmental pressures compiled in the previous step, the impact on ecosystem services are mapped using table 8 in section 3.3 (also in Appendix 3 ). 


\subsubsection{Assessment of the impact on ecosystem services in the reference scenario}

In the previous step, the ecosystem services potentially impacted by pressures resulting from planned maritime activities where identified. In this step, the impacts from the pressures on the identified ecosystem services are either dismissed or confirmed in the same manner as in the reference scenario, step 2. A corresponding assessment of the severity of the impact on ecosystem services is done also for the planning scenario.

\subsubsection{Practical application -Step 3. Identification and description of}

(a) planning scenario(s)

Figure 6 below illustrates the proposed activities in the fictive planning scenario, the geographical as well as analytical delimitation are indicated by the red square. Figure 6: The proposed activities in the fictive planning scenario and the geographical as well as
analytical delimitation (the red square)

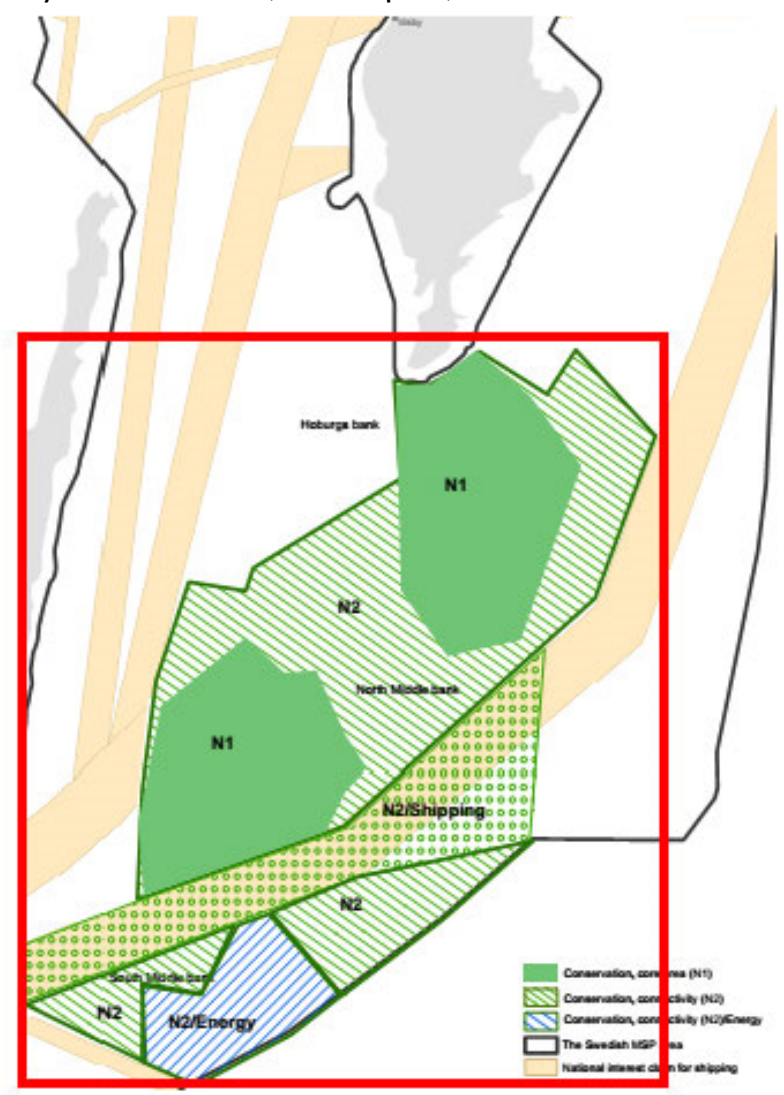




\subsubsection{Which activities are planned in the policy area?}

The maritime sector activities in the planned scenario area listed along with information on spatial claim, economic significance and if available, number of associated jobs.

Table 19: Planned activities in the policy area under the alternative planning scenario

\begin{tabular}{l|rll} 
Planned activity & $\begin{array}{r}\text { Spatial claim } \\
\left(\mathrm{m}^{2}, \mathrm{~km}^{2}, \mathrm{ha}, \%\right)\end{array}$ & Economic significance* & Number of associated jobs to the activity \\
Marine transports. & $6,000 \mathrm{~km}^{2}$. & $\begin{array}{l}\text { Approximately } 30,000 \text { ships } \\
\text { per year passing through the } \\
\text { area (southern route) }\end{array}$ & $\mathrm{N} / \mathrm{A}$ \\
$\begin{array}{l}\text { Marine energy } \\
\text { production. }\end{array}$ & $1,000 \mathrm{~km}^{2}$. & Profit: EUR 2 M /year, 30 years. & $\begin{array}{l}100 \text { jobs for } 2 \text { years in the building phase. } \\
5 \text { jobs for } 30 \text { years in the production phase. } \\
50 \text { jobs for 1 year in the decommissioning } \\
\text { phase. }\end{array}$ \\
\hline
\end{tabular}

Note: *E.g. number of ship passages or shipped tonnage/year by a navigational route, profit (EUR/yr/ha, EUR/yr.

\subsubsection{What environmental pressures are expected to result from the planned activities?}

By making use of Table 7 in section 3.2, the following pressures have been linked to the maritime activities marine transport and energy production.

Table 20: Environmental pressures linked to shipping and renewable energy in the planning scenario

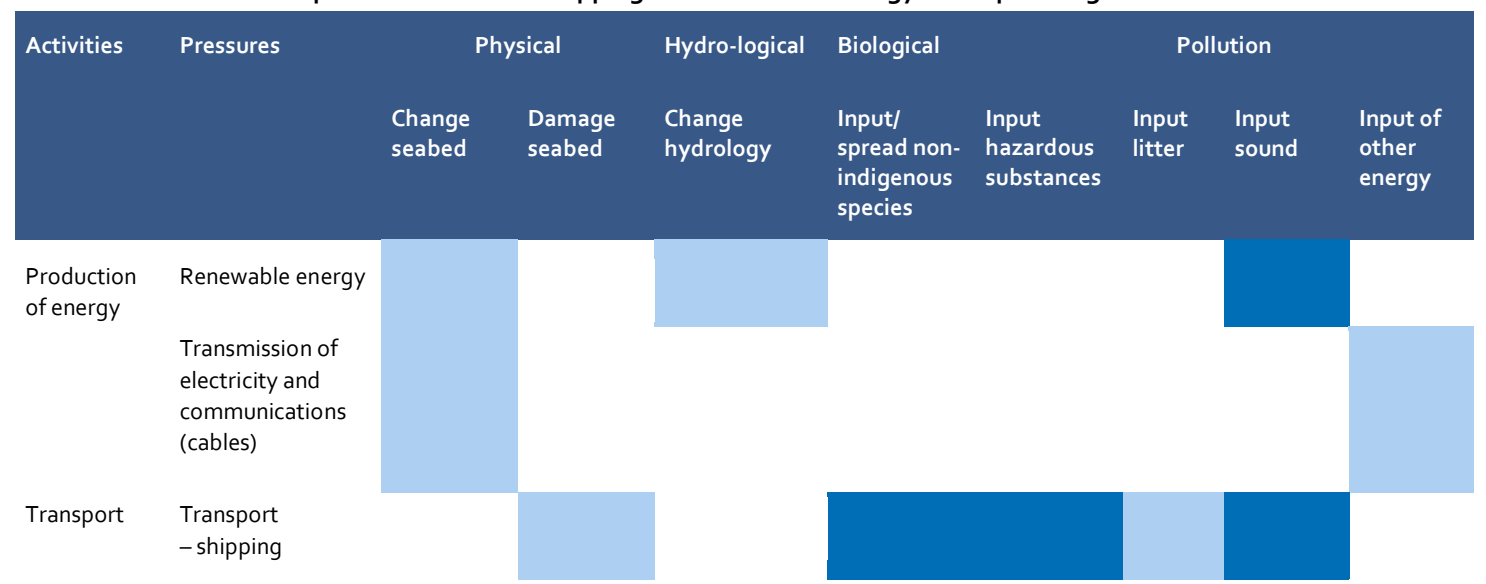

Note: The dark (greater pressure) and light (lesser pressure) cells act only as a very general guide as to the relative importance of each pressure for each activity. 
Table 21: A few of the planned maritime activities inflict the same environmental pressures

\begin{tabular}{lll} 
Activity & & Pressure \\
\hline Production of energy & $\begin{array}{l}\text { Renewable energy production } \\
\text { Transmission of electricity and communication (cables) }\end{array}$ & Physical - Change Seabed \\
Production of energy & Renewable energy production & Pollution - Input sound \\
Transport & Transport-shipping & \\
\hline
\end{tabular}

The activities inflicting the same pressure will be evaluated separately to identify individual contributions to cumulative effects.

3.4.21 What ecosystem services are impacted by which environmental pressures?

The environmental pressures from planned activities that were identified in the previous step are linked to affected ecosystem services by making use of Table 8 in section 3.3. The original list of pressures is shortened and covers only the pressures relevant in the policy area. 
Table 22: Ecosystem services affected by the identified environmental pressures

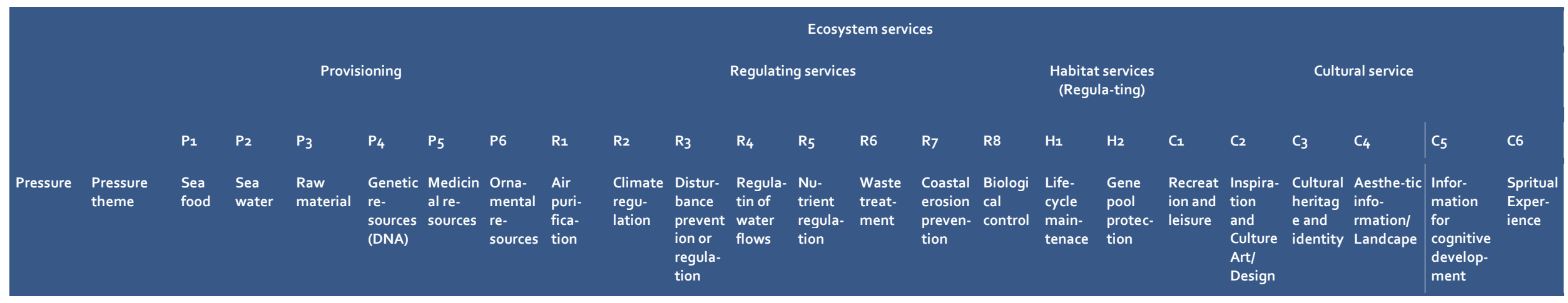

Physical
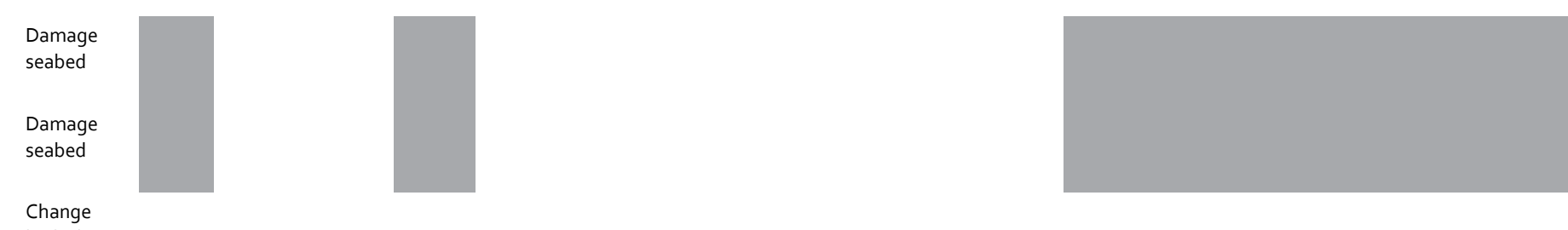

hydrology

Biological
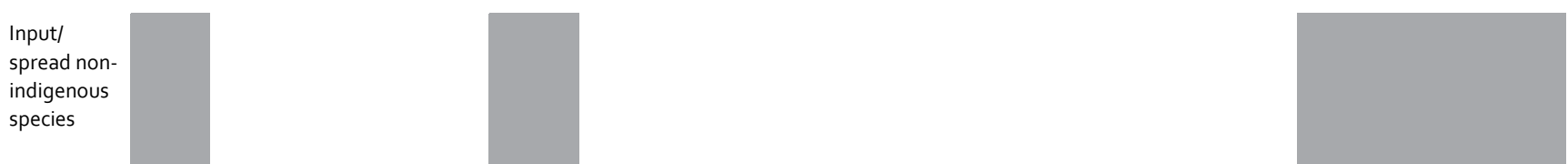


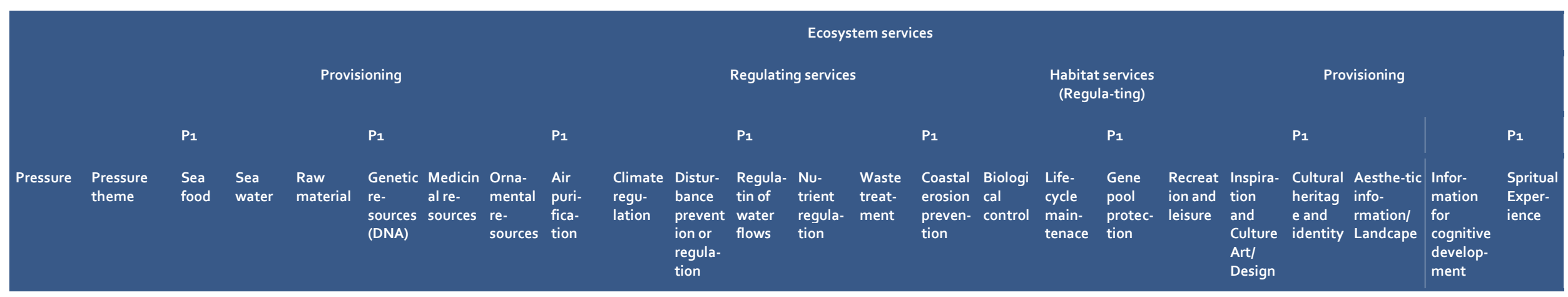

Pollution
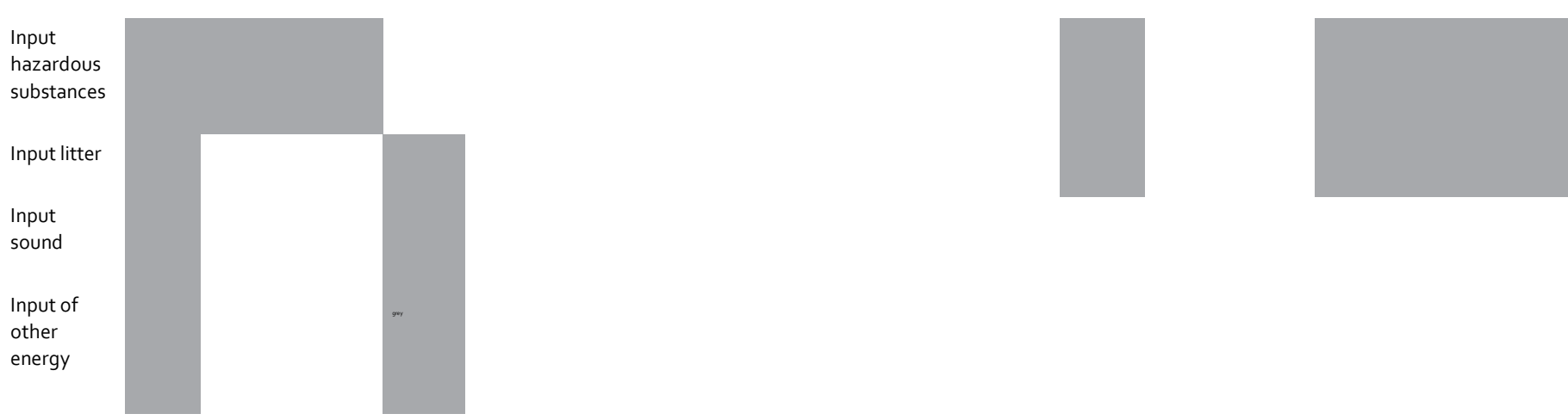
Assessment of the impact on ecosystem services in the reference scenario In the previous step, the ecosystem services potentially impacted by pressures resulting from the planned maritime activities (see Table 14) where identified and summarized (see Table 16). In this step, the impacts from the pressures on the identified ecosystem services are assessed in the same manner as for the reference scenario.

The following pressures were identified as relevant with regards to the planned activities:

- Physical-Change seabed.

- Physical-Damage seabed.

- Hydrological-Change hydrology.

- Biological - Input/Spread non-indigenous species.

- Pollution - Input hazardous substances.

- Pollution - Input marine litter.

- Pollution - Input sound.

The impact on ecosystem services due to human activities in the planning scenario is assessed in the same manner as for the reference scenario and presented without arguments in Tables 23-31 below.

Table 23: Physical - Change seabed; Renewable energy production

\begin{tabular}{|c|c|c|c|c|c|c|c|c|c|c|c|c|}
\hline & $P_{1}$ & $P_{2}$ & $P_{3}$ & $\mathrm{P}_{4}$ & R6 & R7 & R8 & $\mathrm{H}_{1}$ & $\mathrm{H}_{2}$ & $C_{1}$ & $C_{3}$ & $C_{4}$ \\
\hline $\begin{array}{l}\text { Pressure; } \\
\text { Physical - } \\
\text { Change } \\
\text { seabed; } \\
\text { Renewable } \\
\text { energy } \\
\text { production }\end{array}$ & $\begin{array}{l}\text { Sea } \\
\text { food }\end{array}$ & $\begin{array}{l}\text { Sea } \\
\text { water }\end{array}$ & $\begin{array}{l}\text { Raw } \\
\text { ma- } \\
\text { terial }\end{array}$ & $\begin{array}{l}\text { Genetic } \\
\text { re- } \\
\text { sources } \\
\text { (DNA) }\end{array}$ & $\begin{array}{l}\text { Waste } \\
\text { treat- } \\
\text { ment }\end{array}$ & $\begin{array}{l}\text { Coastal } \\
\text { erosion } \\
\text { preven- } \\
\text { tion }\end{array}$ & $\begin{array}{l}\text { Bio- } \\
\text { logical } \\
\text { control }\end{array}$ & $\begin{array}{l}\text { Life- } \\
\text { cycle } \\
\text { main- } \\
\text { tenace }\end{array}$ & $\begin{array}{l}\text { Gene } \\
\text { pool } \\
\text { protec- } \\
\text { tion }\end{array}$ & $\begin{array}{l}\text { Recrea- } \\
\text { tion and } \\
\text { leisure }\end{array}$ & $\begin{array}{l}\text { Cultural } \\
\text { heritage } \\
\text { and } \\
\text { identity }\end{array}$ & $\begin{array}{l}\text { Aesthetic } \\
\text { information } \\
\text { / Landscape }\end{array}$ \\
\hline & & & & & & & & & & & & \\
\hline Size & 2 & & & & 2 & & 2 & 2 & 2 & & & 2 \\
\hline Severity & 2 & & & & 1 & & 2 & 2 & 1 & & & 1 \\
\hline Irreversibility & 2 & & & & 2 & & 2 & 2 & 2 & & & 2 \\
\hline $\begin{array}{l}\text { Overall } \\
\text { impact score } \\
\text { ( ( criteria 1-3) }\end{array}$ & 6 & & & & 5 & & 6 & 6 & 5 & & & 5 \\
\hline
\end{tabular}


Table 24: Physical - Change seabed; Transmission of electricity and communication (cables)

\begin{tabular}{|c|c|c|c|c|c|c|c|c|c|c|c|c|}
\hline & $\mathbf{P}_{1}$ & $\mathbf{P}_{2}$ & $P_{3}$ & $P_{4}$ & R6 & R7 & $\mathbf{R} 8$ & $\mathrm{H}_{1}$ & $\mathrm{H}_{2}$ & $\mathrm{C}_{1}$ & $C_{3}$ & $C_{4}$ \\
\hline $\begin{array}{l}\text { Pressure; } \\
\text { Physical - } \\
\text { Change } \\
\text { seabed; } \\
\text { Transmission } \\
\text { of electricity } \\
\text { and } \\
\text { communicati } \\
\text { on (cables) }\end{array}$ & $\begin{array}{l}\text { Sea } \\
\text { food }\end{array}$ & $\begin{array}{l}\text { Sea } \\
\text { water }\end{array}$ & $\begin{array}{l}\text { Raw } \\
\text { mater- } \\
\text { ial }\end{array}$ & $\begin{array}{l}\text { Gene- } \\
\text { tic re- } \\
\text { sources } \\
\text { (DNA) }\end{array}$ & $\begin{array}{l}\text { Waste } \\
\text { treat- } \\
\text { ment }\end{array}$ & $\begin{array}{l}\text { Coastal } \\
\text { ero- } \\
\text { sion } \\
\text { preven- } \\
\text { tion }\end{array}$ & $\begin{array}{l}\text { Bio- } \\
\text { logi- } \\
\text { cal } \\
\text { con- } \\
\text { trol }\end{array}$ & $\begin{array}{l}\text { Lif- } \\
\text { ecycle } \\
\text { main- } \\
\text { tenace }\end{array}$ & $\begin{array}{l}\text { Gene } \\
\text { pool } \\
\text { pro- } \\
\text { tec- } \\
\text { tion }\end{array}$ & $\begin{array}{l}\text { Re- } \\
\text { crea- } \\
\text { tion } \\
\text { and } \\
\text { leisure }\end{array}$ & $\begin{array}{l}\text { Cultur } \\
\text { al } \\
\text { heri- } \\
\text { tage } \\
\text { and } \\
\text { iden- } \\
\text { tity }\end{array}$ & $\begin{array}{l}\text { Aest- } \\
\text { hetic } \\
\text { infor- } \\
\text { mation/ } \\
\text { Land- } \\
\text { scape }\end{array}$ \\
\hline Size & 1 & & & & & & 1 & & & & & \\
\hline Severity & 1 & & & & & & 1 & & & & & \\
\hline Irreversibility & 1 & & & & & & 1 & & & & & \\
\hline $\begin{array}{l}\text { Overall } \\
\text { impact score } \\
\left(\sum \text { criteria } 1-3\right)\end{array}$ & 3 & & & & & & 3 & & & & & \\
\hline
\end{tabular}

Table 25: Physical - Damage seabed; Transport-shipping

\begin{tabular}{|c|c|c|c|c|c|c|c|c|c|c|c|c|}
\hline & $P_{1}$ & $\mathbf{P}_{2}$ & $P_{3}$ & $P_{4}$ & R6 & R7 & $\mathbf{R 8}$ & $\mathrm{H}_{1}$ & $\mathrm{H}_{2}$ & $C_{1}$ & $C_{3}$ & $\mathrm{C}_{4}$ \\
\hline $\begin{array}{l}\text { Pressure; } \\
\text { Physical - } \\
\text { Damage } \\
\text { seabed }\end{array}$ & $\begin{array}{l}\text { Sea } \\
\text { food }\end{array}$ & $\begin{array}{l}\text { Sea } \\
\text { water }\end{array}$ & $\begin{array}{l}\text { Raw } \\
\text { mater } \\
\text {-ial }\end{array}$ & $\begin{array}{l}\text { Gene- } \\
\text { tic re- } \\
\text { sources } \\
\text { (DNA) }\end{array}$ & $\begin{array}{l}\text { Waste } \\
\text { treat- } \\
\text { ment }\end{array}$ & $\begin{array}{l}\text { Coastal } \\
\text { ero- } \\
\text { sion } \\
\text { preven- } \\
\text { tion }\end{array}$ & $\begin{array}{l}\text { Bio- } \\
\text { logi- } \\
\text { cal } \\
\text { con- } \\
\text { trol }\end{array}$ & $\begin{array}{l}\text { Lif- } \\
\text { ecycle } \\
\text { main- } \\
\text { tenace }\end{array}$ & $\begin{array}{l}\text { Gen } \\
\text { e } \\
\text { pool } \\
\text { pro- } \\
\text { tec- } \\
\text { tion }\end{array}$ & $\begin{array}{l}\text { Re- } \\
\text { crea- } \\
\text { tion } \\
\text { and } \\
\text { leisure }\end{array}$ & $\begin{array}{l}\text { Cultur } \\
\text { al } \\
\text { heri- } \\
\text { tage } \\
\text { and } \\
\text { iden- } \\
\text { tity }\end{array}$ & $\begin{array}{l}\text { Aest- } \\
\text { hetic } \\
\text { infor- } \\
\text { mation } \\
\text { / Land- } \\
\text { scape }\end{array}$ \\
\hline Size & 1 & & & & 2 & 1 & & 1 & & & & 1 \\
\hline Severity & 1 & & & & 1 & 1 & & 1 & & & & 1 \\
\hline Irreversibility & 1 & & & & 1 & 1 & & 1 & & & & 1 \\
\hline $\begin{array}{l}\text { Overall } \\
\text { impact score } \\
\text { ( } \sum \text { criteria 1-3) }\end{array}$ & 3 & & & & 4 & 3 & & 3 & & & & 3 \\
\hline
\end{tabular}


Table 26: Hydrological - Change hydrology; Renewable energy production

\begin{tabular}{|c|c|c|c|c|c|c|c|c|c|c|c|c|}
\hline & $P_{1}$ & $\mathrm{P}_{2}$ & $P_{3}$ & $\mathrm{P}_{4}$ & R6 & R7 & R8 & $\mathrm{H}_{1}$ & $\mathrm{H}_{2}$ & $C_{1}$ & $C_{3}$ & $C_{4}$ \\
\hline $\begin{array}{l}\text { Pressure; } \\
\text { Hydrological - } \\
\text { Change } \\
\text { hydrology }\end{array}$ & $\begin{array}{l}\text { Sea } \\
\text { food }\end{array}$ & $\begin{array}{l}\text { Sea } \\
\text { water }\end{array}$ & $\begin{array}{l}\text { Raw } \\
\text { mater- } \\
\text { ial }\end{array}$ & $\begin{array}{l}\text { Genetic } \\
\text { re- } \\
\text { sources } \\
\text { (DNA) }\end{array}$ & $\begin{array}{l}\text { Waste } \\
\text { treat- } \\
\text { ment }\end{array}$ & $\begin{array}{l}\text { Coastal } \\
\text { erosion } \\
\text { preven- } \\
\text { tion }\end{array}$ & $\begin{array}{l}\text { Bio- } \\
\text { logical } \\
\text { control }\end{array}$ & $\begin{array}{l}\text { Life- } \\
\text { cycle } \\
\text { main- } \\
\text { tenace }\end{array}$ & $\begin{array}{l}\text { Gene } \\
\text { pool } \\
\text { protec- } \\
\text { tion }\end{array}$ & $\begin{array}{l}\text { Recrea- } \\
\text { tion } \\
\text { and } \\
\text { leisure }\end{array}$ & $\begin{array}{l}\text { Cultural } \\
\text { heritage } \\
\text { and } \\
\text { identity }\end{array}$ & $\begin{array}{l}\text { Aesthetic } \\
\text { informa- } \\
\text { tion/ } \\
\text { Landscape }\end{array}$ \\
\hline & 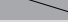 & & & 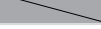 & & & & & - & & & \\
\hline \multicolumn{13}{|l|}{ Size } \\
\hline \multicolumn{13}{|l|}{ Severity } \\
\hline Irreversibility & & & & & & & & & & & & \\
\hline $\begin{array}{l}\text { Overall impact } \\
\text { score } \\
\text { ( } \text { criteria 1-3) }\end{array}$ & & & & & & & & & & & & \\
\hline
\end{tabular}

Table 27: Biological - Input/Spread non-indigenous species; Transport-shipping

\begin{tabular}{|c|c|c|c|c|c|c|c|c|c|c|c|c|}
\hline & $P_{1}$ & $\mathbf{P}_{2}$ & $P_{3}$ & $\mathrm{P}_{4}$ & R6 & R7 & R8 & $\mathrm{H}_{1}$ & $\mathrm{H}_{2}$ & $C_{1}$ & $C_{3}$ & $\mathrm{C}_{4}$ \\
\hline $\begin{array}{l}\text { Pressure; } \\
\text { Biological - } \\
\text { Input/Spread } \\
\text { non-indigenous } \\
\text { species }\end{array}$ & $\begin{array}{l}\text { Sea } \\
\text { food }\end{array}$ & $\begin{array}{l}\text { Sea } \\
\text { water }\end{array}$ & $\begin{array}{l}\text { Raw } \\
\text { mater- } \\
\text { ial }\end{array}$ & $\begin{array}{l}\text { Genetic } \\
\text { re- } \\
\text { sources } \\
\text { (DNA) }\end{array}$ & $\begin{array}{l}\text { Waste } \\
\text { treat- } \\
\text { ment }\end{array}$ & $\begin{array}{l}\text { Coastal } \\
\text { erosion } \\
\text { preven- } \\
\text { tion }\end{array}$ & $\begin{array}{l}\text { Bio- } \\
\text { logical } \\
\text { control }\end{array}$ & $\begin{array}{l}\text { Life- } \\
\text { cycle } \\
\text { main- } \\
\text { tenace }\end{array}$ & $\begin{array}{l}\text { Gene } \\
\text { pool } \\
\text { protec- } \\
\text { tion }\end{array}$ & $\begin{array}{l}\text { Recrea- } \\
\text { tion and } \\
\text { leisure }\end{array}$ & $\begin{array}{l}\text { Cultural } \\
\text { heritag } \\
\text { e and } \\
\text { identity }\end{array}$ & $\begin{array}{l}\text { Aesthetic } \\
\text { informa- } \\
\text { tion/ } \\
\text { Landscape }\end{array}$ \\
\hline Size & 2 & & & 4 & & & & 2 & 2 & & & \\
\hline Severity & 2 & & & 3 & & & & 3 & 3 & & & \\
\hline Irreversibility & 4 & & & 4 & & & & 4 & 4 & & & \\
\hline $\begin{array}{l}\text { Overall impact } \\
\text { score } \\
\text { ( } \text { criteria 1-3) }\end{array}$ & 8 & & & 11 & & & & 9 & 9 & & & \\
\hline
\end{tabular}


Table 28: Pollution - Input hazardous substances; Transport-shipping

\begin{tabular}{|c|c|c|c|c|c|c|c|c|c|c|c|c|}
\hline & $\mathrm{P}_{1}$ & $\mathbf{P}_{2}$ & $P_{3}$ & $P_{4}$ & R6 & R7 & R8 & $\mathrm{H}_{1}$ & $\mathrm{H}_{2}$ & $\mathrm{C}_{1}$ & $\mathrm{C}_{3}$ & $C_{4}$ \\
\hline $\begin{array}{l}\text { Pressure; } \\
\text { Pollution- } \\
\text { Input } \\
\text { hazardous } \\
\text { substances }\end{array}$ & $\begin{array}{l}\text { Sea } \\
\text { food }\end{array}$ & $\begin{array}{l}\text { Sea } \\
\text { water }\end{array}$ & $\begin{array}{l}\text { Raw } \\
\text { mater- } \\
\text { ial }\end{array}$ & $\begin{array}{l}\text { Gene- } \\
\text { tic re- } \\
\text { sources } \\
\text { (DNA) }\end{array}$ & $\begin{array}{l}\text { Waste } \\
\text { treat- } \\
\text { ment }\end{array}$ & $\begin{array}{l}\text { Coastal } \\
\text { ero- } \\
\text { sion } \\
\text { preven } \\
\text {-tion }\end{array}$ & $\begin{array}{l}\text { Bio- } \\
\text { logi- } \\
\text { cal } \\
\text { con- } \\
\text { trol }\end{array}$ & $\begin{array}{l}\text { Lif- } \\
\text { ecycle } \\
\text { main- } \\
\text { tenace }\end{array}$ & $\begin{array}{l}\text { Gene } \\
\text { pool } \\
\text { pro- } \\
\text { tec- } \\
\text { tion }\end{array}$ & $\begin{array}{l}\text { Re- } \\
\text { crea- } \\
\text { tion } \\
\text { and } \\
\text { leisure }\end{array}$ & $\begin{array}{l}\text { Cultural } \\
\text { heri- } \\
\text { tage } \\
\text { and } \\
\text { iden- } \\
\text { tity }\end{array}$ & $\begin{array}{l}\text { Aest- } \\
\text { hetic } \\
\text { infor- } \\
\text { mation/ } \\
\text { Land- } \\
\text { scape }\end{array}$ \\
\hline & & & & & & & & & & & & \\
\hline Size & 4 & & & & 4 & & & 2 & 2 & & & \\
\hline Severity & 2 & & & & 2 & & & 3 & 3 & & & \\
\hline Irreversibility & 2 & & & & 2 & & & 2 & 2 & & & \\
\hline $\begin{array}{l}\text { Overall } \\
\text { impact score } \\
\left(\sum \text { criteria } 1-3\right)\end{array}$ & 8 & & & & 8 & & & 7 & 7 & & & \\
\hline
\end{tabular}

Table 29: Pollution - Input marine litter; Transport-shipping

\begin{tabular}{|c|c|c|c|c|c|c|c|c|c|c|c|c|}
\hline & $P_{1}$ & $\mathbf{P}_{2}$ & $P_{3}$ & $P_{4}$ & R6 & R7 & R8 & $\mathrm{H}_{1}$ & $\mathrm{H}_{2}$ & $\mathrm{C}_{1}$ & $\mathrm{C}_{3}$ & $\mathrm{C}_{4}$ \\
\hline $\begin{array}{l}\text { Pressure; } \\
\text { Pollution- } \\
\text { Input marine } \\
\text { litter }\end{array}$ & $\begin{array}{l}\text { Sea } \\
\text { food }\end{array}$ & $\begin{array}{l}\text { Sea } \\
\text { water }\end{array}$ & $\begin{array}{l}\text { Raw } \\
\text { mater- } \\
\text { ial }\end{array}$ & $\begin{array}{l}\text { Gene- } \\
\text { tic re- } \\
\text { source } \\
\text { s } \\
\text { (DNA) }\end{array}$ & $\begin{array}{l}\text { Waste } \\
\text { treat- } \\
\text { ment }\end{array}$ & $\begin{array}{l}\text { Coasta } \\
\text { l ero- } \\
\text { sion } \\
\text { preven } \\
\text {-tion }\end{array}$ & $\begin{array}{l}\text { Bio- } \\
\text { logi- } \\
\text { cal } \\
\text { con- } \\
\text { trol }\end{array}$ & $\begin{array}{l}\text { Lif- } \\
\text { ecycle } \\
\text { main- } \\
\text { tenace }\end{array}$ & $\begin{array}{l}\text { Gene } \\
\text { pool } \\
\text { pro- } \\
\text { tec- } \\
\text { tion }\end{array}$ & $\begin{array}{l}\text { Re- } \\
\text { crea- } \\
\text { tion } \\
\text { and } \\
\text { leisure }\end{array}$ & $\begin{array}{l}\text { Cultural } \\
\text { heri- } \\
\text { tage } \\
\text { and } \\
\text { iden- } \\
\text { tity }\end{array}$ & $\begin{array}{l}\text { Aest- } \\
\text { hetic } \\
\text { infor- } \\
\text { mation/ } \\
\text { Land- } \\
\text { scape }\end{array}$ \\
\hline Size & 1 & & & & & & & 1 & & 4 & & 4 \\
\hline Severity & 2 & & & & & & & 2 & & 1 & & 1 \\
\hline Irreversibility & 1 & & & & & & & 1 & & 1 & & 1 \\
\hline $\begin{array}{l}\text { Overall } \\
\text { impact score } \\
\text { ( } \sum \text { criteria 1-3) }\end{array}$ & 4 & & & & & & & 4 & & 6 & & 6 \\
\hline
\end{tabular}


Table 30: Pollution - Input sound; Renewable energy production

\begin{tabular}{|c|c|c|c|c|c|c|c|c|c|c|c|c|}
\hline & $P_{1}$ & $\mathbf{P}_{2}$ & $P_{3}$ & $\mathrm{P}_{4}$ & R6 & $\mathrm{R}_{7}$ & R8 & $\mathrm{H}_{1}$ & $\mathrm{H}_{2}$ & $\mathrm{C}_{1}$ & $C_{3}$ & $C_{4}$ \\
\hline $\begin{array}{l}\text { Pressure; } \\
\text { Pollution- } \\
\text { Input sound; } \\
\text { Renewable } \\
\text { energy } \\
\text { production }\end{array}$ & $\begin{array}{l}\text { Sea } \\
\text { food }\end{array}$ & $\begin{array}{l}\text { Sea } \\
\text { water }\end{array}$ & $\begin{array}{l}\text { Raw } \\
\text { mater- } \\
\text { ial }\end{array}$ & $\begin{array}{l}\text { Genetic } \\
\text { re- } \\
\text { sources } \\
\text { (DNA) }\end{array}$ & $\begin{array}{l}\text { Waste } \\
\text { treat- } \\
\text { ment }\end{array}$ & $\begin{array}{l}\text { Coastal } \\
\text { erosion } \\
\text { preven- } \\
\text { tion }\end{array}$ & $\begin{array}{l}\text { Bio- } \\
\text { logical } \\
\text { control }\end{array}$ & $\begin{array}{l}\text { Life- } \\
\text { cycle } \\
\text { main- } \\
\text { tenace }\end{array}$ & $\begin{array}{l}\text { Gene } \\
\text { pool } \\
\text { protec- } \\
\text { tion }\end{array}$ & $\begin{array}{l}\text { Recrea- } \\
\text { tion } \\
\text { and } \\
\text { leisure }\end{array}$ & $\begin{array}{l}\text { Cultural } \\
\text { heritage } \\
\text { and } \\
\text { identity }\end{array}$ & $\begin{array}{l}\text { Aesthetic } \\
\text { informa- } \\
\text { tion/ } \\
\text { Landscape }\end{array}$ \\
\hline \multicolumn{13}{|l|}{ Size } \\
\hline \multicolumn{13}{|l|}{ Severity } \\
\hline Irreversibility & & & & & & & & & & & & \\
\hline $\begin{array}{l}\text { Overall } \\
\text { impact score } \\
\text { ( } \text { criteria 1-3) }\end{array}$ & & & & & & & & & & & & \\
\hline
\end{tabular}

Table 31: Pollution - Input sound; Transport-shipping

\begin{tabular}{|c|c|c|c|c|c|c|c|c|c|c|c|c|}
\hline & $P_{1}$ & $\mathrm{P}_{2}$ & $P_{3}$ & $P_{4}$ & R6 & $\mathrm{R}_{7}$ & R8 & $\mathrm{H}_{1}$ & $\mathrm{H}_{2}$ & $C_{1}$ & $C_{3}$ & $C_{4}$ \\
\hline $\begin{array}{l}\text { Pressure; } \\
\text { Pollution - } \\
\text { Input sound; } \\
\text { Transport- } \\
\text { shipping }\end{array}$ & $\begin{array}{l}\text { Sea } \\
\text { food }\end{array}$ & $\begin{array}{l}\text { Sea } \\
\text { water }\end{array}$ & $\begin{array}{l}\text { Raw } \\
\text { mater- } \\
\text { ial }\end{array}$ & $\begin{array}{l}\text { Genetic } \\
\text { re- } \\
\text { sources } \\
\text { (DNA) }\end{array}$ & $\begin{array}{l}\text { Waste } \\
\text { treat- } \\
\text { ment }\end{array}$ & $\begin{array}{l}\text { Coastal } \\
\text { erosion } \\
\text { preven- } \\
\text { tion }\end{array}$ & $\begin{array}{l}\text { Bio- } \\
\text { logical } \\
\text { control }\end{array}$ & $\begin{array}{l}\text { Life- } \\
\text { cycle } \\
\text { main- } \\
\text { tenace }\end{array}$ & $\begin{array}{l}\text { Gene } \\
\text { pool } \\
\text { protec- } \\
\text { tion }\end{array}$ & $\begin{array}{l}\text { Recrea- } \\
\text { tion } \\
\text { and } \\
\text { leisure }\end{array}$ & $\begin{array}{l}\text { Cultural } \\
\text { heritage } \\
\text { and } \\
\text { identity }\end{array}$ & $\begin{array}{l}\text { Aesthetic } \\
\text { informa- } \\
\text { tion/ } \\
\text { Landscape }\end{array}$ \\
\hline \multicolumn{13}{|l|}{ Size } \\
\hline \multicolumn{13}{|l|}{ Severity } \\
\hline Irreversibility & & & & & & & & & & & & \\
\hline $\begin{array}{l}\text { Overall } \\
\text { impact score } \\
\text { ( } \text { criteria 1-3) }\end{array}$ & & & & & & & & & & & & \\
\hline
\end{tabular}


Table 32: The impact scores in the planning scenario are compiled and presented

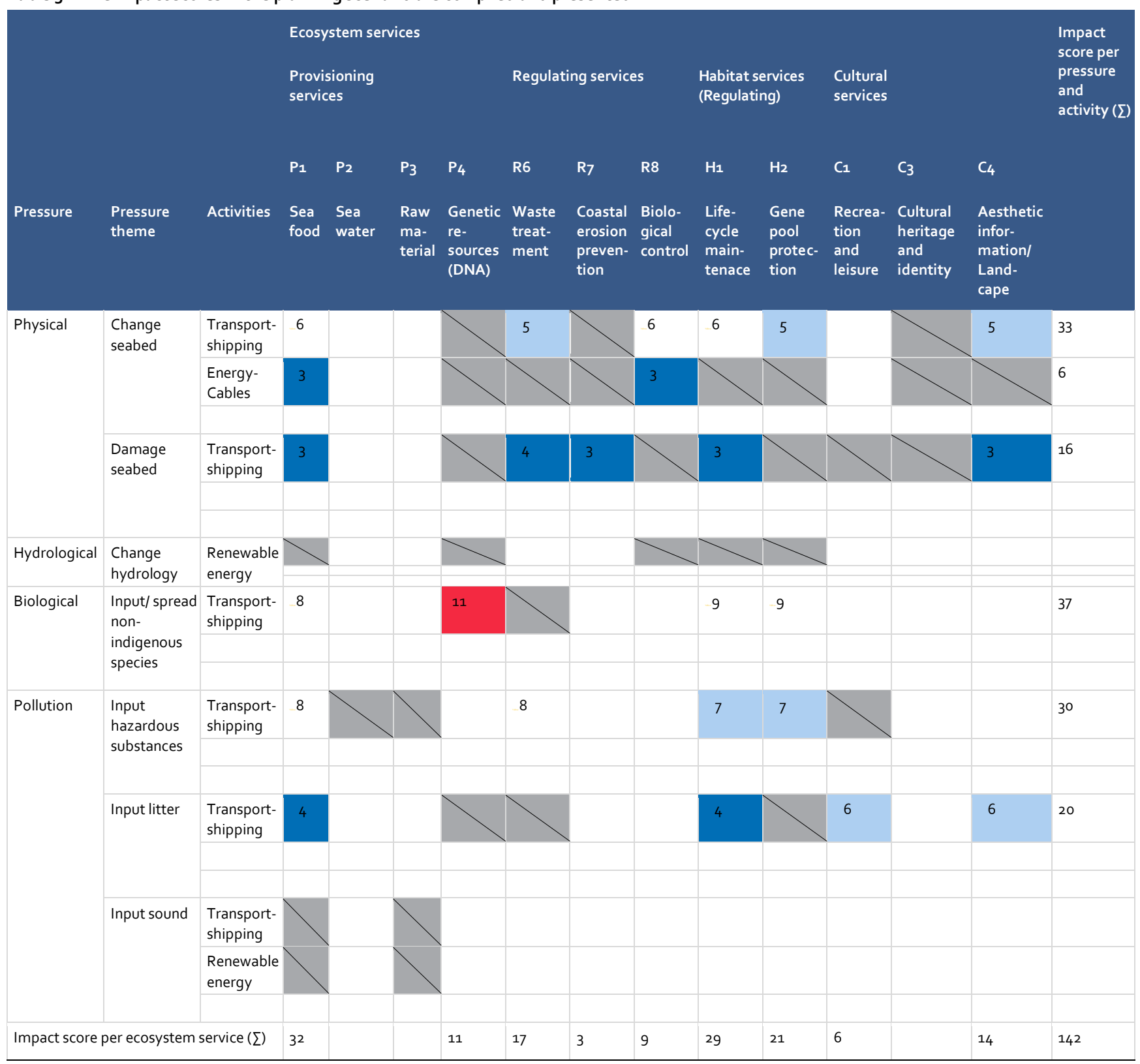




\subsubsection{Step 4. Identification of consequences of planning scenarios}

In this step, it will become evident to what extent opposing planning scenarios will result in conflicting interest between maritime sectors and activities regarding the impact and dependency on ecosystem services:

- What are the changes in maritime activities resulting from the relevant scenarios?

- What are the resulting changes in the provision and quality of ecosystem services?

- What activities, other than those subjected to planning, are impacted by changes in the provision and quality of ecosystem services?

- What are the consequences from the relevant scenarios with regards to achieving Good Environmental Status (GES) according to the Marine Strategy Framework Directive (2008/56/EC)?7

\subsubsection{Practical application - Step 4. Identification of consequences of planning scenarios}

What are the changes in maritime activities resulting from the relevant scenarios? The results from steps 2 and 3 are compiled for comparisons and recorded in Table 33 below.

Table 33: Changes in activities in terms of spatial claim, economic significance and employment represented by alternative planning scenarios

\begin{tabular}{|c|c|c|c|c|}
\hline \multirow{2}{*}{$\begin{array}{l}\text { Activities } \\
\text { in the } \\
\text { reference } \\
\text { scenario }\end{array}$} & \multirow{2}{*}{$\begin{array}{l}\text { Activities in the } \\
\text { planning } \\
\text { scenario }\end{array}$} & \multicolumn{3}{|l|}{ Changes in } \\
\hline & & $\begin{array}{l}\text { spatial claim } \\
\left(\mathrm{m}^{2}, \mathrm{~km}^{2}, \mathrm{ha}, \%\right)\end{array}$ & $\begin{array}{l}\text { economic } \\
\text { significance* }\end{array}$ & number of associated jobs \\
\hline \multirow[t]{2}{*}{ Shipping. } & Shipping. & $\begin{array}{l}50 \% \text { of the area used for } \\
\text { navigational routes is closed. } \\
\text { (the northern route). }\end{array}$ & $\begin{array}{l}20,000 \text { ship passages a year } \\
\text { are moved to the southern } \\
\text { navigational route. }\end{array}$ & N/A \\
\hline & $\begin{array}{l}\text { Renewable } \\
\text { energy. }\end{array}$ & $\begin{array}{l}10 \% \text { of the policy area is } \\
\text { claimed. }\end{array}$ & $\begin{array}{l}\text { Annual profit of EUR } 2 \mathrm{M} \text { for } \\
30 \text { years. }\end{array}$ & $\begin{array}{l}100 \text { jobs for } 2 \text { years in the buliding phase. } \\
5 \text { jobs for } 30 \text { years in the production phase. } \\
50 \text { jobs for } 1 \text { year in the decommissioning } \\
\text { phase. }\end{array}$ \\
\hline
\end{tabular}

Note: $\quad$ *E.g. number of ship passages or shipped tonnage/year by a navigational route, profit (EUR/yr/ha, EUR/yr).

\footnotetext{
7 This issue is not investigated further within the scope of this report, however, information on the links between GES descriptors/criteria and ecosystem services are available in publications from the ODEMM (http://odemm.com/) and the Marecos project (Hasler et al. 2016).
} 


\subsubsection{What are the resulting changes in the provision and quality of ecosystem services?}

The results from step 2 and 3 regarding the impact on ES are compiled and filled in Table 34

The summed results from the impact assessments for the reference and the alternative planning scenario are compiled and the changes with regards to all relevant ecosystem services are evaluated.

Table 34: Impact assessment scores from the reference scenario and the planning scenario are summarized and presented together

\begin{tabular}{|c|c|c|c|c|c|c|c|c|c|c|c|c|c|}
\hline & Ecosy & tem ser & rices & & & & & & & & & & \\
\hline & Provi & oning & & & & & & $\begin{array}{l}\text { Habitat } \\
\text { (Regula }\end{array}$ & $\begin{array}{l}\text { services } \\
\text { ting) }\end{array}$ & Cultural & services & & $\begin{array}{l}\text { Impact } \\
\text { score per }\end{array}$ \\
\hline & $P_{1}$ & $\mathbf{P}_{2}$ & $P_{3}$ & $\mathrm{P}_{4}$ & R6 & R7 & R8 & $\mathrm{H}_{1}$ & $\mathrm{H}_{2}$ & $\mathrm{C}_{1}$ & $C_{3}$ & $C_{4}$ & \\
\hline Scenario & $\begin{array}{l}\text { Sea } \\
\text { food }\end{array}$ & $\begin{array}{l}\text { Sea } \\
\text { water }\end{array}$ & $\begin{array}{l}\text { Raw } \\
\text { mater- } \\
\text { ial }\end{array}$ & $\begin{array}{l}\text { Gene- } \\
\text { tic re- } \\
\text { sources } \\
\text { (DNA) }\end{array}$ & $\begin{array}{l}\text { Waste } \\
\text { treat- } \\
\text { ment }\end{array}$ & $\begin{array}{l}\text { Coastal } \\
\text { ero- } \\
\text { sion } \\
\text { preven- } \\
\text { tion }\end{array}$ & $\begin{array}{l}\text { Bio- } \\
\text { logi- } \\
\text { cal } \\
\text { con- } \\
\text { trol }\end{array}$ & $\begin{array}{l}\text { Lif- } \\
\text { ecycle } \\
\text { main- } \\
\text { tenace }\end{array}$ & $\begin{array}{l}\text { Gene } \\
\text { pool } \\
\text { pro- } \\
\text { tec- } \\
\text { tion }\end{array}$ & $\begin{array}{l}\text { Re- } \\
\text { crea- } \\
\text { tion } \\
\text { and } \\
\text { leisure }\end{array}$ & $\begin{array}{l}\text { Cultural } \\
\text { heri- } \\
\text { tage } \\
\text { and } \\
\text { iden- } \\
\text { tity }\end{array}$ & $\begin{array}{l}\text { Aest- } \\
\text { hetic } \\
\text { infor- } \\
\text { mation/ } \\
\text { Land- } \\
\text { scape }\end{array}$ & \\
\hline $\begin{array}{l}\text { Reference } \\
\text { scenario }\end{array}$ & 25 & & & 11 & 13 & 3 & & 26 & 17 & 6 & & 10 & 111 \\
\hline $\begin{array}{l}\text { Alternative } \\
\text { scenario }\end{array}$ & 32 & & & 11 & 17 & 3 & 9 & 29 & 21 & 6 & & 14 & 142 \\
\hline $\begin{array}{l}\text { Impact } \\
\text { change }(\Sigma)\end{array}$ & 7 & & & 0 & 4 & 0 & 9 & 3 & 4 & 0 & & 4 & 31 \\
\hline
\end{tabular}

\subsubsection{Step 5. Control station: are the scenarios correctly defined?}

Before continuing the analysis with economic valuation, distributional analysis etc. it is time to review the assumptions and delimitations that have been the point of departure for the analysis. Below is an indicative list of issues that may be highlighted in the review:

- Is the geographical delimitation and scope sufficient?

- Are all relevant activities included?

- Are the changes in activities correctly defined?

- Are the environmental pressures correctly defined? 
If e.g. it is found that the geographical delimitation is too narrow, or unnecessarily large, the analysis starts over at step 1 with relevant adjustments. Or if it for example becomes clear that some aspects initially left out from the definition of the reference or policy scenario need to be included, the analysis is looped back to step 2 or 3 .

\subsubsection{Step 6. Valuation of changes in provision and quality of ecosystem services}

The mapping and description of consequences on the ecosystem services as outlined in step 3 is followed by valuation of changes in the provision of ecosystem services. The point of departure of the valuation is guided by the purpose of the analysis. If for example two opposing planning scenarios are evaluated, the economic impacts from the changes in the provision of ecosystem services represented by the alternatives are explored. This also includes effects on maritime activities not subjected to planning but which may be dependent upon the same ecosystem services that are impacted by the plans.

Not all effects can be valued in monetary terms. In many cases the changes in the provision of ecosystem services need to be described semi-quantitatively (with scores), quantitatively (supported by an indicator representing the ecosystem service in terms of some physical unit, e.g. hectares of habitat), or qualitatively. The valuation-step is based in the following:

- What valuation techniques may be used, given the types of ecosystem services and other costs and benefits that are to be valued?

- Perform valuation of the identified changes in provision and quality of ecosystem services.

\subsubsection{Practical application - Step 6. Valuation of changes in provision and quality of ecosystem services}

What valuation techniques may be used, given the types of ecosystem services subjected to changes as well as other costs and benefits that are to be valued? Changes with regards to the activities themselves: This step involves trying to monetize the identified impacts. Most of the impacts are described in a qualitative way and/or units that do not lend themselves directly to economic valuation, the exceptions are found in the Economic significance column of Table 20, containing monetized or monetizable estimates of the proposed changes.

The potential economic costs of moving traffic to the southern navigational route is identified as costs for increased numbers of travel hours, fuel, personnel, depreciation 
etc. for affected ships. The annual profit from building windfarms in the designated area is estimated in this fictive example to EUR $2 \mathrm{M}$ for 30 years.

\begin{tabular}{|c|c|c|c|c|}
\hline \multirow{2}{*}{$\begin{array}{l}\text { Activities in the } \\
\text { reference } \\
\text { scenario }\end{array}$} & \multirow{2}{*}{$\begin{array}{l}\text { Activities in } \\
\text { the planning } \\
\text { scenario }\end{array}$} & \multicolumn{3}{|c|}{ Changes in } \\
\hline & & $\begin{array}{l}\text { spatial claim }\left(\mathrm{m}^{2}, \mathrm{~km}^{2} \text {, }\right. \\
\mathrm{ha}, \%)\end{array}$ & economic significance* & $\begin{array}{l}\text { number of associated } \\
\text { jobs }\end{array}$ \\
\hline \multirow[t]{2}{*}{ Shipping. } & Shipping. & $\begin{array}{l}50 \% \text { of the area used for } \\
\text { navigational routes is closed } \\
\text { (the northern route). }\end{array}$ & $\begin{array}{l}20000 \text { ship passages a year } \\
\text { are moved to the southern } \\
\text { navigational route. }\end{array}$ & \\
\hline & $\begin{array}{l}\text { Renewable } \\
\text { energy. }\end{array}$ & $\begin{array}{l}10 \% \text { of the policy area is } \\
\text { claimed. }\end{array}$ & $\begin{array}{l}\text { Annual profit of EUR } 2 \mathrm{M} \\
\text { for } 30 \text { years. }\end{array}$ & $\begin{array}{l}100 \text { jobs for } 2 \text { years in the } \\
\text { building phase. } \\
5 \text { jobs for } 30 \text { years in the } \\
\text { production phase. } \\
50 \text { jobs for } 1 \text { year in the } \\
\text { decommissioning phase. }\end{array}$ \\
\hline
\end{tabular}

Note: *E.g. number of ship passages or shipped tonnage/year by a navigational route, profit (EUR/yr/ha, EUR/yr).

The provision and quality of ecosystem services: The changes in the provision and quality of ecosystem services from the reference and planned scenario are compiled in Table 34 , these changes can be valued using different techniques depending on the specific ES in question.

Perform valuation of the identified changes in provision and quality of ecosystem services

Changes with regards to the activities themselves: The economic costs for the shipping companies of moving the navigational route southward is zero; assuming that the new navigational routes do not lengthen or shorten the distance travelled. However, if that was the case, we would need estimates of additional distance travelled per trip/ship, multiplied by the annual number of ships moved from the northern to the southern route (assumed to be all 20,000 ships travelling there today); and multiplied with the market prices of the additional fuel and other cost components that varies with distance travelled.

The annual economic benefits from the off-shore wind power plant can be valued as the net annual income (profit) of the electricity production, which is assumed to be EUR 2,000,000. The creation of new jobs could be important locally in Gotland, but in cost-benefit analysis in countries with high employment rates (like Sweden) they are 
usually not counted as economic benefits (at the national level). However, in the description of distributional aspects the local/regional benefits of creation of new jobs could be mentioned.

The provision and quality of ecosystem services

Provisioning services: For the provisioning services the planning project has an impact score of 9 and 4 for biological control (invasive species) and waste treatment (hazardous substances, marine litter), respectively. These impacts can also be valued by new stated preference surveys or value transfer from existing studies based on a comparison of impacts valued in these studies and the impacts in the planning project. While there have been SP surveys quite recently on the impacts on recreational use and non-use values from eutrophication in the Baltic Sea (Ahtiainen et al. 2014), there are very few Nordic studies on invasive marine species and hazardous waste and litter. There is however one very recent Norwegian study on how coastal recreation is affected by marine litter and other visual intrusions (Aanesen et al. 2016). For the provisioning service of sea food, with an impact score of 7 , the expected change in annual catch of affected species (here mainly halibut) would have to be quantified (in $\mathrm{kg}$ ) to be valued by the market price of the affected commercially caught species.

Habitat services: For the habitat services $\left(\mathrm{H}_{1}\right.$ and $\mathrm{H}_{2}$ with impact scores from the project of 3 and 4 , respectively), the seabed impact from shipping and construction/operation and decommission of wind power turbines and seabed electric transmission cables (disturbance (due to e.g. anchoring) in terms of impacts on recruitment of commercial fish species (e.g. halibut) could be valued by the estimated change in annual catch and market prices for the different species. If the fish species are threatened by extinction by the project, non-use values should also be added, see e.g. Aanesen et al. (2015) for an example of a stated preference study valuing the nonuse values of Norwegian cold water corals (which are important for marine fish species). To transfer values from this study, we would need to know the impact of the present project in quantitative terms to be able to compare the extent of the damage from the planning alternative with the one valued in Northern Norway.

Damages to habitats for the support of wintering birds could be valued in the same way by transferring values from stated preference studies of the use value (birdwatching) and non-use value of bird habitats. SP studies that have looked at marine birdlife are typically valuing damages from oil spills; see Navrud et al. (2016) for a recent Norwegian study. As these oil spill valuation studies typically value impacts on a wide range of ecosystem services, a main challenge in value transfer of impacts on birdlife to our context would be to isolate the part of the value estimate which is motivated by this only. 
Cultural services: The negative impacts of off-shore wind farm in terms of aesthetics $\left(\mathrm{C}_{4}\right)$ are assessed to increase the impact score by 4 . Landscape (or in this case: seascape) aesthetic impacts have been valued by stated preference (SP) techniques, and the geographically closest study to transfer estimates from would be the Danish SP study of off-shore wind by Ladenburg (2009). To our knowledge, there are no similar studies for the negative aesthetic impacts from maritime transport, and some people even have a benefit of watching ships pass by.

If all these annual benefits and costs were monetized, they should be added over the time horizon of the planning project (e.g. 30 years); using a social discount rate (e.g. $4 \%$ per year) to calculate the Net Present Value (NPV) of the project. If NPV>0, social benefits exceed the social costs, and the project is profitable from society's point of view. However, for concluding whether the project is profitable it is typically also necessary to take non-monetized benefits and costs into account.

\subsubsection{Step 7. Distributional analysis}

Not only total benefits and costs should be assessed, decision makers also need to consider the distribution of these costs and benefits between all affected interest groups. For this reason, a distributional analysis should be undertaken to support and underpin decision making with regards to alternative or opposing planning alternatives.

In this step, all interest groups affected should be identified. An interest group is defined as a group of people or companies (e.g. consumers, producers and NGOs representing people and nature) that get their wellbeing and/or income affected by changes in the provision and quality of ecosystem services; positively or negatively. Note that each person can be a member of many interest groups, e.g. if you are a commercial fisherman living in the local community, using the marine and coastal area for recreational and also care about preserving the biodiversity of these areas; you will be a member of all the interest groups listed in the Table 36 below. The table below provides an example of how distributional impacts could be reported. 


\begin{tabular}{|c|c|c|c|}
\hline Interest groups & $\begin{array}{l}\text { Description of impact, and } \\
\text { whether positive }(+) \text { or } \\
\text { negative }(-)\end{array}$ & $\begin{array}{l}\text { Non-monetary valuation } \\
\text { (semi-quantitative, } \\
\text { quantitative or } \\
\text { qualitative) }\end{array}$ & Monetary valuation \\
\hline Commercial fishermen. & $\begin{array}{l}\text { (+) Increased net income due } \\
\text { to increased catch for the same } \\
\text { fishing effort. }\end{array}$ & & $\begin{array}{l}\text { Euro XX (estimated as } \\
\text { increase in catch times } \\
\text { market prices for the catch } \\
\text { (separate analysis for each } \\
\text { affected fish species) }\end{array}$ \\
\hline $\begin{array}{l}\text { Local community } \\
\text { - recreational users. }\end{array}$ & $\begin{array}{l}\text { (+) Reduced eutrophication } \\
\text { improves conditions for } \\
\text { swimming }\end{array}$ & & \\
\hline $\begin{array}{l}\text { Local community } \\
\text {-non-users }\end{array}$ & $\begin{array}{l}\text { (+) Reduced eutrophication } \\
\text { increase diversity of species. }\end{array}$ & & \\
\hline Etc. & & & \\
\hline
\end{tabular}

\subsubsection{Practical application - Step 7. Distributional analysis}

The main interest groups affected will be (remember that one person can be a member of many interest groups, so overlapping groups are to be expected):

- Households in Gotland will experience negative aesthetic impacts from the offshore wind farms and negative impacts (lost non-use values) on other ecosystem services, but would benefits in terms of jobs created and also the benefits (nonuse values) of preservation.

- Given that the scope of the analysis is not strictly confined to the geographical boundaries of the policy area (see Step 1, Scooping the analysis, p. 37), then households in other parts of Sweden (and other Baltic countries if the CBA is conducted on the Baltic Sea area level) would also be included. These households would benefit if the affected fish and bird species are nationally important, threatened species (non-use values), and if they visited Gotland as tourists their recreational use value of the affected area might increase.

- Owners of ships in traffic in this part of the Baltic Sea (Could get increased operating cost from closure of the northern route), which might increase their operational costs (buy assumed to be zero). 
- Owners of the off-shore windfarm; which will get the profits from renewable electricity production.

- Halibut fishermen, which might get reduced catches and/or increased operating costs to catch the same amount of halibut.

- Bird watchers, which might get reduced recreational value from not seeing the affected long tail duck as frequently.

The distributional effects are summarized in Table 37 below.

Table 37: Table for recording the distribution of impacts on interest groups, qualitatively (description), quantitatively (non-monetary) and monetary valuation of impacts; and an example

\begin{tabular}{|c|c|c|c|}
\hline Interest groups & $\begin{array}{l}\text { Description of impact, } \\
\text { positive (+) or negative (-) }\end{array}$ & $\begin{array}{l}\text { Non-monetary Valuation } \\
\text { (semi-quantitative, } \\
\text { quantitative or qualitative) }\end{array}$ & Monetary valuation \\
\hline Households in Gotland. & $\begin{array}{l}\text { (-) Negative aesthetic } \\
\text { impacts from the off-shore } \\
\text { wind farms. }\end{array}$ & & $\begin{array}{l}\text { Decreased value for affected (sea } \\
\text { view) properties. (Hedonic pricing } \\
\text { methods) }\end{array}$ \\
\hline Households in Gotland. & $\begin{array}{l}\text { (-) Negative impacts from } \\
\text { the loss of other ecosystem } \\
\text { services, e.g. Habitat services }\end{array}$ & $\begin{array}{l}\text { Semi-quantitative assess- } \\
\text { ment (scales), quantitatively } \\
\text { (e.g. affected areas) or } \\
\text { qualitatively (words). }\end{array}$ & $\begin{array}{l}\text { Or alternatively, by means of SP- } \\
\text { valuation techniques. }\end{array}$ \\
\hline Households in Gotland & $\begin{array}{l}\text { (+) Positive impact from } \\
\text { increased protection } \\
(\mathrm{N} 2000)\end{array}$ & $\begin{array}{l}\text { Semi-quantitative assess- } \\
\text { ment (scales), quantitatively } \\
\text { (e.g. affected areas) or } \\
\text { qualitatively (words). }\end{array}$ & $\begin{array}{l}\text { Or alternatively, by means of SP- } \\
\text { valuation techniques. }\end{array}$ \\
\hline Households in Gotland & $\begin{array}{l}(+) \text { Increased job } \\
\text { opportunities. }\end{array}$ & & \\
\hline $\begin{array}{l}\text { Households in other } \\
\text { parts of Sweden. }\end{array}$ & $\begin{array}{l}\text { (+) Positive impact from } \\
\text { increased protection } \\
(\mathrm{N} 2000) \text {. }\end{array}$ & $\begin{array}{l}\text { Semi-quantitative assess- } \\
\text { ment (scales), quantitatively } \\
\text { (e.g. affected areas) or } \\
\text { qualitatively (words). }\end{array}$ & $\begin{array}{l}\text { Or alternatively, by means of SP- } \\
\text { valuation techniques. }\end{array}$ \\
\hline $\begin{array}{l}\text { Owners of ships in } \\
\text { traffic in this part of the } \\
\text { Baltic Sea -non-users. }\end{array}$ & $\begin{array}{l}\text { (-) Potentially increased } \\
\text { costs due to longer travelling } \\
\text { distances in the Baltic Sea. }\end{array}$ & & $\begin{array}{l}\text { Costs for the increased numbers of } \\
\text { travel hours, fuel, personnel, } \\
\text { depreciation etc. }\end{array}$ \\
\hline $\begin{array}{l}\text { Owners of the off-shore } \\
\text { windfarm. }\end{array}$ & $\begin{array}{l}\text { (+) Profit from establishing } \\
\text { wind farms in the area. }\end{array}$ & & $\begin{array}{l}\text { EUR } 2 \text { M/Year (estimated profit from } \\
\text { windfarms). }\end{array}$ \\
\hline Halibut fishermen. & $\begin{array}{l}\text { (-) Decreased catch due to } \\
\text { decreased recruitment }\end{array}$ & & $\begin{array}{l}\text { Market prices for halibut and } \\
\text { increased cost for operations. }\end{array}$ \\
\hline Bird watchers. & $\begin{array}{l}\text { (-) Reduced recreational } \\
\text { value from not seeing the } \\
\text { affected long tail duck as } \\
\text { frequently. }\end{array}$ & $\begin{array}{l}\text { Semi-quantitative assess- } \\
\text { ment (scales), quantitatively } \\
\text { (e.g. affected areas) or } \\
\text { qualitatively (words) }\end{array}$ & $\begin{array}{l}\text { Or alternatively, by means of SP or } \\
\text { RP valuation techniques. }\end{array}$ \\
\hline
\end{tabular}




\subsubsection{Step 8. Sensitivity analysis}

The purpose of the sensitivity analysis is to investigate different sources of uncertainty regarding the analysis, and to what extent they might affect the outcome of the analysis. Factors of uncertainty (e.g. choice of social discounting rate, scales for semiquantitative assessments etc.) can be altered and used to calculate uncertainty intervals to highlight the level of sensitivity in the methodology used for the impact assessment. The sensitivity assessment thus revolves around the following questions:

- What factors are the most significant contributors to uncertainty regarding the result of the analysis?

- How might the result change given that parameters are varied within individual uncertainty ranges?

\subsubsection{Practical application-Step 8. Sensitivity analysis}

What factors are the most significant contributors to uncertainty regarding the result of the analysis? Important uncertainty factors to consider, both one-by-one and in combinations include:

- Uncertainties in the assessment of semi-quantitative impacts.

- Uncertainties in the process needed to "translate" semi-quantitative impacts into impacts quantified in units that lends themselves to economic valuation.

- Uncertainties in the valuation and value transfer methods.

- Uncertainties in the estimates for unit values from market prices or revealed and stated preference surveys used in value transfer exercises.

How might the result change given that parameters are varied within individual uncertainty ranges?

- The results regarding semi-quantitative impact assessments are tested to reveal uncertainty intervals and consequently to investigate how the assessment results (overall impact index) might differ within the group of affected ecosystem services.

- The uncertainty of the monetized impacts, deduced by means of different valuation techniques (e.g. stated preference (SP) techniques, revealed preferences (RP) techniques, value transfer, market prices etc.) are analysed by varying the relevant uncertainty factors to reveal uncertainty intervals. 


\subsubsection{Step 9. Conclusions: Are the tradeoffs socially desirable?}

Are the estimated changes in wellbeing desirable or not?

There are four main types of tradeoffs considered central in ecosystem services assessment (Magnussen et al. 2013):

- Between goods and services: Use and management of water resources may enhance one or a few services or use areas, at the expense of others.

- Over time: Management may give benefits in the short run, but negative impacts and costs at a later point in time. For management and use of natural resources the long-term perspective is normally of great importance.

- Between interest groups: Prioritizing of use areas which are important for some interest groups compared to others. If such tradeoffs have to be made, it may be that some groups mainly receive the benefits while others bear the costs.

- Spatial: Different kinds of regulations or management regimes may give benefits and costs that are spatially differentiated. These tradeoffs may be more or less inter-related. However, we will discuss each of them in turn.

Tradeoffs between goods and services and over time are traditionally handled in welfare economic analysis while this is not the case for the latter two because these aspects are considered to be distributional/equity effects. However, these issues may be of great importance in practice, because they relate to who should pay for the improvements.

\subsubsection{Practical application - Step 9}

The planning scenario has economic consequences for the activities shipping and renewable energy. These consequences are summarized in Table 37. It is assumed that the economic cost of moving the navigational routes southwards is zero, assuming the travelling distance is not changed. Establishing the renewable energy facilities in the planning scenario gives an annual profit of EUR 2,000,000 per year in 30 years. Thus, the planning scenario creates more economic benefits and jobs compared to the reference alternative.

Tradeoffs between goods and services: From Table 38 we can see that the planning scenario over all have larger negative impacts on ecosystem services compared to the reference scenario. Provisioning, as well as habitat services and cultural services are negatively impacted by the planning scenario. All ecosystem services are either negatively impacted or not impacted at all. Thus, the main tradeoffs to be made are 
between economic benefits of the planning scenario and the non-priced negative impacts on the ecosystem services sea food, waste treatment, biological control, lifecycle maintenance, gene pool protection, and aesthetic information/landscape.

Table 38: Goods and services to be considered in the tradeoff between the reference and the planning scenario

\begin{tabular}{|c|c|c|c|}
\hline Goods and services & Reference scenario & Planning scenario & Comment \\
\hline Renewable energy & No change in impact & (+) EUR 2M/year (30 years) & \\
\hline Shipping & No change in impact & (-) Increased costs & $\begin{array}{l}\text { Longer travelling time, increased fuel consumption, personnel } \\
\text { costs etc. }\end{array}$ \\
\hline \multicolumn{4}{|l|}{ Ecosystem services } \\
\hline P1 Sea food & No change in impact & Increased negative impact; +7 & Valued by market prices on commercially caught fish (halibut). \\
\hline R6 Waste treatment & No change in impact & Increased negative impact $;+4$ & \\
\hline R7 Biological control & No change in impact & Increased negative impact $;+9$ & \\
\hline $\mathrm{H}_{1}$ Lifecycle maintenance & No change in impact & Increased negative impact; +3 & As for $\mathrm{P}_{1}$ Sea food \\
\hline $\mathrm{H}_{2}$ Gene pool protection & No change in impact & Increased negative impact; +4 & \\
\hline $\begin{array}{l}\mathrm{C}_{4} \text { Aesthetic } \\
\text { information/landscape }\end{array}$ & No change in impact & Increased negative impact; +4 & Valued by stated or revealed preferences techniques \\
\hline
\end{tabular}

Tradeoffs over time: According to the project description, the planning scenario will contribute to economic benefits the coming 30 years, while it is reasonable to assume that the fishing and habitat services etc. have an even longer life time. From the information we have, we cannot say for sure if the impacts will continue after the 30 years' lifetime of the windmills, or if the impacts on ecosystem services will be back to pre-project level when or if the windmills are removed in 30 years.

We know that the economic benefits of the off-shore windmills are EUR 2,000,000 per year in 30 years. If, for simplicity, we assume that the negative impacts on ecosystem services are equal each of these years and last for these 30 years and then are reversible, our economic framework tells us that if the negative impacts on ecosystem services are less than EUR 2,000,000 per year, the project is socially desirable. Is it reasonable to believe that this is the case? In future use of this tool on real projects, one should aim at valuing as many of the impacts on ecosystem services as possible, as this will simplify the overall tradeoffs. In this example, lacking these value estimates, one approach is to consider how much the affected population would have to be willing to pay every year in order to make the planning scenario beneficial to society - that is estimating the tipping-point or break-even. It is not quite obvious if the population in Gotland only or in total Sweden, should be considered to be the affected population. The population of Gotland is approximately 60,000 , and in Sweden nearly $10,000,000$. If we assume that people in Gotland only is the relevant population, each 
person must be willing to pay (EUR 2,000,000/60,000=) EUR 33 per year. This is not a large sum per person. However, as we have seen, the households in Gotland also receives benefits in the form of job opportunities and conservation of nature areas, which makes it more difficult to decide if the planning scenario is overall desirable. Using the tool in practice, we should study the impacts in more detail and work further on the valuation of ecosystem services impacted in order to be more decisive.

Tradeoffs regarding spatial considerations and interest groups: Table 37 summarizes the distributional effects of impacts, for monetized and non-monetized values. We can see that the interest groups also represent different spatial tradeoffs. The table shows that the households in Gotland receive most positive as well as negative impacts. The positive impacts are increased job opportunities and increased protection of nature conservation areas, while they receive negative impacts in the form of aesthetic impacts and loss of other ecosystem services. The table further illustrates that the group that receives the largest positive impacts is the owners of the off-shore windfarm. Further, the households in Sweden and in Gotland receive benefits of increased Natura 2000 protection, and as already mentioned; more job opportunities for people in Gotland (and possibly other parts of Sweden). All other interest groups receive negative impacts of the planning scenario, amongst them halibut fishermen who receive decreased catch due to decreased halibut recruitment.

\section{Conclusions from the tradeoff analysis}

- The planning scenario includes an off-shore windfarm, moving of shipping routes and protection of nature areas. The windfarm will generate benefits estimated to EUR 2,000,000 per year in 30 years.

- The impact on ecosystem services is negative. People living at Gotland will experience most of the negative impacts on ecosystem services, including reduced recruitment of halibut.

- A simplified break-even analysis shows that each person in Gotland would have to pay at least EUR 33 per year to avoid these negative impacts. This corresponds to approximately EUR 70 per household in Gotland per year.

- The economic benefits of the planning scenario will go to the owners of the windfarm, while the people of Gotland will bear most of the costs in the shape of reduced quality and quantity of ecosystem services. 



\section{Conclusions}

The methodology for assessing impacts on ecosystem services from maritime activities put forward in this study is at an early stage of development and there is a need for further improvement and elaboration of most of its parts. The study however, clearly shows that making use of the proposed methodology enables and facilitates the incorporation of and accounting for ecosystem services in the planning process.

Since the arrival of the ecosystem services typologies proposed in MEA in 2005, TEEB in 2010, and CICES in 2012, the adaptations of ecosystem services typologies to various habitats, environments and applied purposes have continued. One such example is the typology of marine ecosystem services put forward in this study, elaborated by Böhnke Henrichs et al. (2013) and specially adapted to marine spatial planning applications. In order to further facilitate ecosystem services analysis in marine spatial planning, and other applied contexts, there is a need for further adaptation and development of the indicators used for evaluation of changes in the provision and quality of ecosystem services as well. Future studies need to focus on improving the alignment of indicators used to evaluate ecosystem services and indicators applied in MSFD and BSAP (HELCOM). Optimally, the same indicators should be used to evaluate the impacts on Good Environmental Status (GES) from environmental pressures originating from maritime activities and ecosystem services at the same time. This would improve the possibility to account for the economic and ecological sustainability dimensions simultaneously in the planning process and hence, arrive at socially more desirable solutions.

\subsection{Potential for further development of the methodology}

During the course of the project, a number of areas with potential for improvement have been identified:

- The scores applied in the study for evaluation of impact on ecosystem services are not fully adapted to assess positive impacts. If the impact on a specific ecosystem service decreases as a result of planning scenarios, then the positive effect is illustrated in a lowered impact score. But a situation where there is no adverse 
effect on a specific ecosystem service in the reference scenario, and the planning scenario implies an improvement, then the positive effect is not covered by the present score system. An example may be found in the positive effects from enlargement of protected areas, or the establishment of corridors between separated protected areas. Positive effects from such changes can not be handled by the present scoring system, instead they are accounted for in the part of the methodology dealing with distributional effects of different planning scenarios.

- Several maritime activities and sectors have a bidirectional relationship to the ecosystem services, i.e. their environmental pressures cause impacts on the provision and quality of ecosystem services at the same time as they are dependent on them. Other activities are dependent on ecosystem services which are negatively impacted by environmental pressures of other sectors and activities. This study has taken a first step to include mapping and assessment of the dependency on ecosystem services of different sectors and activities. The purpose was to include a systematic method for establishing links between the sectors /activities causing environmental impact and the resulting loss of benefits and wellbeing among other sectors or stakeholders. Even though such assessments are considered important contributions to the overall methodology, it has not been possible to include in the study at this stage for resource reasons.

- The methodology presented in this study is illustrated by a fictive planning scenario. In order to facilitate further development, e.g. according to the bullets above, the methodology needs to be applied to a real world case study. In addition to the scoring, this would also offer the possibility to demonstrate how monetized economic valuation of positive and negative effects on ecosystem services from alternative planning scenarios can be applied, as well as analysis of distributional effects and tradeoffs between opposing or alternative planning scenarios. 


\section{References}

Aanesen, M, C. Armstrong, M. Czajkowski, J. Falk-Petersen, N. Hanley and S. Navrud 2015: Willingness to pay for unfamiliar public goods: Preserving cold-water corals in Norway. Ecological Economics 112; 53-67. https://doi.org/10.1016/j.ecolecon.2015.02.007

Aanesen, M., J. Falk-Andersson, K. Vondolia, T. Borch, S. Navrud and D. Tinch 2016: Valuing the coastal zone for private recreational services. The case of Northern Norway. Draft paper. Arctic University of Norway, Tromsø.

Agardy, T., Bridgewater, P., Crosby, M.P., Day, J., Dayton, P.K., Kenchington, R., Laffoley, D., McConney, P., Murray, P.A., Parks, J.E., Peau, L., 2003: Dangerous targets? Unresolved issues and ideological clashes around marine protected areas. Aquatic Conservation: Marine and Freshwater Ecosystems 13, 353-367. https://doi.org/10.1002/aqc.583

Ahtiainen, Heini; Janne Artell, Mikolaj Czajkowski, Berit Hasler, Linus Hasselström, Kari Hyytiäinen, Jürgen Meyerhoff, James C.R. Smart, Tore Söderqvist, Katrin Zimmer, Julia Khaleeva, Olga Rastrigina, Heidi Tuhkanen 2013.Public preferences regarding use and condition of the Baltic Sea - An international comparison informing marine policy. Marine Policy 42; 20-30. https://doi.org/10.1016/j.marpol.2013.01.011

Ahtiainen, Heini; Janne Artell, Mikołaj Czajkowski, Berit Hasler, Linus Hasselström, Anni Huhtala, Jürgen Meyerhoff, James CR Smart, Tore Söderqvist, Mohammed H Alemu, Daija Angeli, Kim Dahlbo, Vivi Fleming-Lehtinen, Kari Hyytiäinen, Aljona Karlõševa, Yulia Khaleeva, Marie Maar, Louise Martinsen, Tea Nõmmann, Kristine Pakalniete, leva Oskolokaite, Daiva Semeniene 2014. Benefits of meeting nutrient reduction targets for the Baltic Sea -a contingent valuation study in the nine coastal states. Journal of Environmental Economics and Policy 3 (3); 278-305.

Bateman, I., R. Brouwer, M. Cranford, S. Hime, E. Ozdemiroglu, Z. Phang and A. Provins 2009: Valuing Environmental Impacts: Practical Guidelines for the Use of Value Transfer in Policy and Project Appraisal. Value Transfer Guidelines. Eftec, London. Submitted to Department for Environment, Food and Rural Affairs (Defra), London, UK, December 2009.

Bateman, I. J.; Brouwer, R.; Ferrini, S.; Schaafsma, M; Barton, D..N.; Dubgaard, A.; Hasler, B.; Hime, S.; Liekens, I.; S. Navrud; De Nocker, L.; Sceponaviciute, R.; Semeniene, D. 2011. Making Benefit Transfers Work: Deriving and Testing Principles for Value Transfers for Similar and Dissimilar Sites Using a Case Study of the Non-Market Benefits of Water Quality Improvements Across Europe. Environmental and Resource Economics 50 (3);365-387. https://doi.org/10.1007/s10640-011-9476-8

Blæsbjerg, M., Pawlak, J.F., Sørensen, T.K. and Vestergaard, O. 2009: Marine Spatial Planning in the Nordic region - Principles, Perspectives and Opportunities. Nordic Council of Ministers. https://doi.org/10.6027/tn2009-528

Boyd, J. and S.Banzhaf 2007. What are ecosystem services? The need for standardized environmental accounting units. Ecological Economics 63: 616-626.

https://doi.org/10.1016/j.ecolecon.2007.01.002 
Bryhn, A., Lindegarth, M., Bergström, L. and Bergström, U. 2015. Ekosystemtjänster från Svenska Hav. Status och påverkansfaktorer. Havs och vattenmyndighetens rapport 2015: 12 .

Böhnke-Henrichs, A., Baulcomb, C., Koss, R., Hussain, S.S. \& de Groot, R.S. 2013. Typology and indicators of ecosystem services for marine spatial planning and management. Journal of Environmental Management 130:135-45. https://doi.org/10.1016/j.jenvman.2013.08.027

COM 2011. The EU Biodiversity Strategy to 2020. http://ec.europa.eu/environment/nature/ biodiversity/strategy/index_en.htm

Desvousges, W.H, F. R. Johnson and H.S. Banzhaf 1998: Environmental Policy Analysis with Limited Information. Principles and Applications of the Transfer Method. New Horizons in Environmental Economics. Edward Elgar, Cheltenham, UK and Northampton, MA, USA.

ECORYS, Deltares, OCEANIC 2012. Blue growth-scenarios and drivers for sustainable growth from the oceans, seas and coasts. Final report for the European Commission, DG MARE. ECORYS, Rotterdam, The Netherlands; August 2012.

Fisher, B. m.fl 2006. Defining and classifying ecosystem services for decision making. Ecological Economics 68: 643-653.

Fyhr, F., Å., Nilsson and A., Nyström Sandman 2013. A review of Ocean Zoning tools and Species distribution modelling methods for Marine Spatial Planning. AquaBiota Water Research, Stockholm, Sweden.

Galparsoro, I., Borja, A. \& Uyarra, M.C. 2014. Mapping ecosystem services provided by benthic habitats in the European North Atlantic Ocean. Frontiners in Marine Sciences, vol. 1 article 23; July 18th 2014. https://doi.org/10.3389/fmars.2014.00023

Garpe, K. 2008. Ecosystem services provided by the Baltic Sea and Skagerrak. Report 5873. Naturvårdsverket, Stockholm, Sweden. ISBN 978-91-620-5873-9.

Hasler B, Ahtiainen H, Hasselström L, Heiskanen A-S, Soutukorva Å, Martinsen L, 2016: Marine ecosystem services in Nordic marine waters and the Baltic Sea-possibilities for valuation. TemaNord 2016:501. Nordic Council of Ministers. http://dx.doi.org/10.6027/TN2016-501

Hattam, Caroline, Jonathan P Atkins, Nicola Beaumont, Tobias Börger, Anne Böhnke-Henrichs, Daryl Burdon, Rudolf De Groot, et al. 2015. Marine Ecosystem Services: Linking Indicators to Their Classification. Ecological Indicators 49: 61-75. https://doi.org/10.1016/j.ecolind.2014.09.026

Hein, L. m.fl. 2006. Spatial scales, stakeholders and the valuation of ecosystem services. Ecological Economics 57 (2), 209-228. https://doi.org/10.1016/j.ecolecon.2005.04.005

HELCOM 2010a. Ecosystem Health of the Baltic Sea. HELCOM Initial Holistic Assessment. Balt. Sea Environ. Proc. No. 122.

HELCOM 2010b. Towards a tool for quantifying anthropogenic pressures and potential impacts on the Baltic Sea marine environment: A background document on the method, data and testing of the Baltic Sea Pressure and Impact Indices. Balt. Sea Environ. Proc. No. 125.

HELCOM 2013. HELCOM Ministerial Declaration (2013) Regional Baltic Maritime Spatial Planning Roadmap 2013-2020. http://www.helcom.fi/Documents/Ministerial2013/ Ministerial\%2odeclaration/Adopted_endorsed\%2odocuments/ Regional\%2oBaltic\%2oMSP\%2oRoadmap.pdf

HELCOM and OSPAR 2003. Joint HELCOM and OSPAR Ministerial Statement on the Ecosystem Approach to the Management of Human Activities.

Hökby, S. and T. Söderqvist 2003. Elasticities of demand and willingness to pay for environmental services in Sweden, Environmental and Resource Economics, 26:361-383. https://doi.org/10.1023/B:EARE.0000003581.97411.75 
Johnston, R., J. Rolfe, R. Rosenberger and R. Brouwer (eds.) 2015. Benefit Transfer of Environmental and Resource Values: A Handbook for Researchers and Practitioners. Springer. Dordrecht, The Netherlands, $582 \mathrm{pp}$.

Jäppinen, J.-P. \& Heliölä, J. (eds.) 2015. Towards a sustainable and genuinely green economy. The value and social significance of ecosystem services in Finland (TEEB for Finland). Synthesis and roadmap. The Finnish Environment 1en/2015. The Finnish Ministry of Environment, Helsinki. 144 p.

Kareiva, P. m.fl. (eds) 2011. Natural Capital - Theory and practice of mapping ecosystem services. Oxford University Press.

Kaul, D., K.J. Boyle, N.V. Kuminoff, C.F. Parmeter, and J.C. Pope 2013. What can we learn from benefit transfer errors? Evidence from 20 years of research on convergent validity. Journal of Environmental Economics and Management, 66, 90-104.

https://doi.org/10.1016/j.jeem.2013.03.001

Kriström, B and M Bonta Bergman. 2014. Samhällsekonomiska analyser av miljöprojekt - en vägledning. Swedish Environmental Protection Agency, Report, 6628, Stockholm, Sweden.

Kriström, B and P. Riera 1996. Is the income elasticity of environmental improvements less than one? Environmental and Resource Economics 7 (1); 45-55.

https://doi.org/10.1007/BFo0420426

Kumar, L. E. Svensson, and A. Markandya (eds.) 2017: Handbook on the Economics and Management for Sustainable Oceans. Edward Elgar Publishing, Cheltenham, UK.

Ladenburg, J. 2009. Visual impact assessment of offshore wind farms and prior experience. Applied Energy, 86(3), 380-387. https://doi.org/10.1016/j.apenergy.2008.05.005

Lindhjem, H. 2007. Non-Timber Benefits from Fennoscandian Forests: A Meta-Analysis. Journal of Forest Economics 12; 251-277. https://doi.org/10.1016/j.jfe.2006.09.003

Loomis, J. 2015. The Use of Benefit Transfer in the United States. Chapter 3 ( $p p$ 61-70) in R. Johnston, J. Rolfe, R. Rosenberger and R. Brouwer (eds.) 2015: Benefit Transfer of Environmental and Resource Values: A Handbook for Researchers and Practitioners. Springer. Dordrecht, The Netherlands, 582 pp. https://doi.org/10.1007/978-94-017-9930-0_3

Lindhjem, H. and S. Navrud 2008. How Reliable are Meta-Analyses for International Benefit Transfer? Ecological Economics 66(2-3); 425-435. https://doi.org/10.1016/j.ecolecon.2007.10.005

Luisetti, T. et al. 2014. Coastal Zone Ecosystem Services: From science to values and decisionmaking; a case study. Science of the Total Environment 493: 682-693.

https://doi.org/10.1016/j.scitotenv.2014.05.099

Maes, J. et al. 2013. Mapping and Assessment of Ecosystems and their Services. An analytical framework for ecosystem assessments under action 5 of the EU biodiversity strategy to 2020 . Publications office of the European Union, Luxembourg.

Maes, et al. 2014. Indicators for mapping ecosystem services. 2nd MAES Working Paper. European Union, doi: 10.2779/75203.

Magnussen, K., H. Lindhjem og J.M. Skjelvik 2012. Samfunnsøkonomiske effekter av forringet miljøtilstand i Nordsjøen og Skagerrak. Vista Analyse rapport 2012/38.

Magnussen, K., H. Lindhjem, C. Armstrong, H. Bergland, E. Mikkelsen, R. Reinvang og J.M. Skjelvik 2013: Verdiskaping og økosystemtjenester i Barentshavet-Lofoten: Synergier og avveininger. Vista Analyse rapport 2013/08.

Marre, J-B. et al. 2015. The use of ecosystem services valuation in Australian coastal zone management. Marine Policy 56: 117-124. https://doi.org/10.1016/j.marpol.2015.02.011 
MEA (Millennium Ecosystem Assessment), 2005. Ecosystems and Human Well-Being: Current State and Trends. Island Press, Washington DC.

Morf, A., J. Perus, S. Steingrímsson, M. Ekenger, S. Evans 2013. Results of the 2nd Nordic Workshop on Marine Spatial Planning and an update for 2014. Nordic Working Papers, Nordic Council of Ministers.

Navrud, S. 2007. Practical tools for value transfer in Denmark-guidelines and an example. Working Report No. 28, 2007, Miljøstyrelsen (Danish Environmental Protection Agency, Copenhagen. http://www2.mst.dk/common/Udgivramme/Frame.asp?pg= http://www2.mst.dk/Udgiv/publications/2007/978-87-7052-656-2/html/kapo6_eng.htm

Navrud, S and R. Ready (eds.) 2007. Environmental Value Transfer: Issues and Methods. Springer, Dordrect, The Netherlands.

Navrud, S., H. Lindhjem and K. Magnussen 2016: Valuing Marine Ecosystem Services Loss from Oil Spills for Use in Cost-Benefit Analysis of Preventive Measures. Forthcoming in Nunes, P. A.L.D., P.

NOU (2012). Samfunnsøkonomiske analyser. Norges offentlige utredninger 2012:16.

Nunes, P.A.L.D., P. Kumar and T. Dedeurwaerdere 2014. Handbook on the Economics of Ecosystem Services and Biodiversity. Edward Elgar Publishing. https://doi.org/10.4337/9781781951514

Polasky, S. m.fl. 2011. Putting ecosystem service models to work: conservation, management, and tradeoffs. I Kareiva, P. m.fl. (eds) (2011) Natural Capital - Theory and practice of mapping ecosystem services. Oxford University Press.

Raheem, N. 2012. Application of non-market valuation to California's coastal policy decisions. Marine Policy 36:1166-1171. https://doi.org/10.1016/j.marpol.2012.01.005

Ready, R.C. S. Navrud, B. Day, R. Dubourg, F. Machado, S. Mourato, F. Spanninks and M.X.V. Rodriquez 2004: Benefit Transfer in Europe. How Reliable Are Transfers Between Countries? Environmental and Resource Economics 29; 67-82.

Salomidi, M., Katsanevakis, S., Borja, A., Braeckman, U., Damalas, D., Galparsoro, I., et al. 2012. Assessment of goods and services, vulnerability, and con-servation status of European seabed biotopes: a stepping stone towards ecosystem-based marine spatial management. Mediterr. Mar. Sci. 13, 49-88. https://doi.org/10.12681/mms.23

Sanchirico, J.N., D. Lew, D. Kling, A. Haynie, and D. Layton 2013. Conservation values in marine ecosystem-based management. Marine Policy 38:523-530.

https://doi.org/10.1016/j.marpol.2012.08.008

Surís-Regueiro, J. C., M. D. Garza-Gil and M. M. Varela-Lafuente 2013. Marine economy: A proposal for its definition in the European Union. Marine Policy 42: 111-124. https://doi.org/10.1016/j.marpol.2013.02.010

SwAM 2013. God Havsmiljö 2020 - Del 1: Del 1: Inledande bedömning av miljötillstånd och socioekonomisk analys. SwAM Report 2012:19.

Söderqvist, T and $\AA$. Soutukorva (2006): An instrument for assessing the quality of environmental valuation studies. Report, Swedish Environmental Protection Agency. (Naturvårdsverket), Stockholm. https://www.naturvardsverket.se/Documents/publikationer/620-1252-5.pdf

Söderqvist, T., Soutukorva, Å., Hasselström, L.2013. Marine spatial planning-socioeconomic analysis as part of a sustainability assessment. SwAM Report 2013:1.

TEEB (2010a). The Economics of Ecosystems and Biodiversity (TEEB): Mainstreaming the Economics of Nature: A synthesis of the approach, conclusions and recommendations of TEEB. 
TEEB (2010b). The Economics of Ecosystems and Biodiversity (TEEB). Ecological and Economic Foundations. Edited by Pushpam Kumar. Earthscan, London and Washington.

Turner, K., Schaafsma, M., Elliott, M., Burdon, D., Atkins, J., Jickells, T., Tett, P., Mee, L., van Leeuwen, S., Barnard, S., Luisetti, T., Paltriguera, L., Palmieri, G. \& Andrews, J. 2014. UK National Ecosystem Assessment Follow-on. Work Package Report 4: Coastal and marine ecosystem services: principles and practice. UNEP-WCMC, LWEC, UK.

UK National Economic Assessment (UK NEA) 2011. The UK National Ecosystem Assessment. Technical Report. UNEP-WCMC, Cambridge.

US EPA 2016: Valuing mortality risk reductions for policy: a meta-analytic approach. Prepared by the U.S. Environmental Protection Agency's Office of Policy, National Center for Environmental Economics for review by the EPA's Science Advisory Board, Environmental Economics Advisory, Washington DC, USA.

Watts, M.E, I.R. Ball, R.R. Stewart, C.J. Klein, K. Wilson, C. Steinback, R. Lourival, L. Kircher, H.P. Possingham. 2009. Marxan with Zones: software for optimal conservation based landand sea-use zoning, Environmental Modelling \& Software (2009), doi:10.1016/ j.envsoft.2009.06.005. http://marxan.net/

Zandersen, M, M. Termansen and F. S. Jensen 2007a. Evaluating Approaches to Predict Recreation Values of New Forest Sites. Forest Economics 13; 103-128. https://doi.org/10.1016/j.jfe.2007.02.003

Zandersen, M, M. Termansen and F. S. Jensen 2007b.Testing Benefits Transfer of Forest Recreation Values over a Twenty-Year Time Horizon. Land Economics 83 (3); 412-440.Values over a Twenty-Year Time Horizon. Land Economics 83 (3); 412-440.

https://doi.org/10.3368/le.83.3.412 



\section{Svensk sammanfattning med slutsatser}

Syftet med denna studie är att beskriva och kommunicera ett förslag till ett nytt verktyg för utvärdering av ekosystemtjänster i fysisk planering till havs i de nordiska länderna. Verktyget bygger på en stegvis metod för hur ekosystemtjänster kan inkluderas i havsplaneringsprocessen genom att man till för ökad kunskap inom de tre hållbarhetsdimensionerna, ekonomi, ekologi och sociala aspekter. Denna enkla och transparenta metod är också avsedd att användas i samverkan med olika intressenter och intressentgrupper, för att öka medvetenhet, förståelse och acceptans, samt till att bidra med underlag till lösningar vid eventuella konflikter kring användningen av de marina resurserna.

\section{Fysisk planering till havs och ekosystemtjänster}

Syftet med fysisk planering till havs är att främja en hållbar användning av de marina resurserna. Tanken är att avvägningar mellan motstående intressen hos olika maritima sektorer ska kunna göras samtidigt som de marina ekosystemen skyddas, den fysiska planeringen till havs är på så sätt tänkt att bidra till att upprätthålla både kvaliteten och tillgången till de marina ekosystemtjänsterna.

Ett av målen inom havsplaneringsdirektivet (MSPD) är att uppnå en fördelning av maritima verksamheter så att de inte kommer i konflikt med varandra eller medför för stora belastningar på det marina ekosystemet och på så sätt möjliggöra ett hållbart utnyttjande av de marina resurserna. I MSPD anges också att medlemsländerna bör tillämpa en ekosystembaserad strategi (definierad i havsmiljödirektivet (2008/56 / EG), MSFD) vid genomförandet av direktivet med syfte att säkerställa att det kollektiva trycket av all verksamhet hålls under nivåer som är förenliga med uppnåendet av god miljöstatus. Att kartlägga marina ekosystemtjänster, och därmed skapa underlag för samstämmiga bedömningar av marina resurser är en förutsättning vid framtagande av hållbara havsplaner.

Ett annat syfte med planeringsprocessen inom MSPD är att fungera som stöd för EU:s medlemsländer när det gäller att uppfylla målen inom andra marina politikområden 
och sektorer. Samtidigt har de marina ekosystemtjänsterna inte beaktats till fullo i medlemsländernas arbete med att utforma målsättningar och delmål inom det marina miljöarbetet, varken inom MSFD eller ramdirektivet för vatten (WFD).

Inom arbetet med EU:s strategi för biologisk mångfald till 2020 (BDS2020) spelar däremot ekosystemtjänsterna en central roll och behovet av att kartlägga och utvärdera tillståndet och värdet på de marina ekosystemtjänsternas betonas tydligt (MAES). Detta motiveras av behovet att kunna värdera nyttor som uppstår till följd av de marina områdesskydden, ett förvaltningsverktyg som bedöms vara av central betydelse för att utarmningen av biologisk mångfald i EU:s medlemsstater ska kunna bromsas (Maes et al. 2013). MSPD ställer också krav på att medlemsländerna ska utforma sina nationella planeringsprocesser på ett sätt som understödjer möjligheten att uppnå målen inom både MSFD och BDS2020 (se appendix 13 angående kopplingen mellan BDS2020 och MSP).

Miljötillståndet $\mathrm{i}$ havet är till stora delar påverkat av miljöbelastningar från omkringliggande länder, många miljöproblem behöver därför hanteras genom internationella samarbeten. Av det skälet betonar både MSPD och MSFD behovet av harmonisering mellan medlemsstaternas metoder för utvärderingar och planeringsprocesser när det gäller den marina miljön. För de nordiska länderna, inklusive Norge som icke-EU medlem, är det internationella samarbetet särskilt viktigt till följd av många gemensamma utmaningarna och gemensamma havsområden. De nordiska havsområdena som sträcker sig från Barents hav i norr, via Nordostatlanten till de danska sunden och vidare genom Egentliga Östersjön till Bottniska viken uppvisar en stor variation av ekosystemtyper. Gemensamt för dem alla är att de delar samma övergripande utmaningar med avseende på havsplanering. En Nordisk samsyn när det gäller ekosystemtjänsternas roll som verktyg i den fysiska planeringen till havs kan vara en utgångspunkt för arbetet med att möta dessa gemensamma utmaningar.

Sedan de tre mest tongivande indelningssystemen för ekosystemtjänster, MEA, TEEB och CICES presenterades har anpassningen av ekosystemtjänsterna fortsatt med inriktningar mot olika habitat, miljöer och tillämpningar. Ett sådant exempel är den ekosystemtjänstindelning med inriktning mot fysisk planering till havs som redovisas $\mathrm{i}$ Böhnke-Henrichs et al. (2013) och som tillämpas i den här studien. För att ytterligare stärka ekosystemtjänstanalysens roll inom havsplaneringen, och andra tillämpade sammanhang, behöver de indikatorer som används för utvärdering av ekosystemtjänster anpassas och förbättras vidare. Framtida studier inom området behöver bl.a. ägnas åt hur ekosystemtjänsternas indikatorer kan samordnas med de indikatorer som används inom MSFD och BSAP (HELCOM) för utvärdering av det marina miljötillståndet. Det vore en fördel om samma indikatorer kunde användas både för att utvärdera den maritima sektorns effekter på miljötillståndet och på de marina 
ekosystemtjänsterna. På så sätt skulle möjligheten att beakta den ekonomiska och ekologiska hållbarhetsdimensionen samtidigt i planeringsprocessen öka och därmed också möjligheten till socialt hållbara lösningar.

\section{Kopplingen mellan marina aktiviteter och ekosystemtjänster}

I metoden som förs fram i studien klargörs kopplingarna mellan marina sektorer och aktiviteter och de marina ekosystemtjänstera i tre huvudsakliga steg. Det första steget omfattar valet av en lämplig indelning för de marina ekosystemtjänsterna som aktiviteterna ska kopplas till. I nuläget finns ett antal övergripande indelningssystem tillgängliga, vissa med specifik tematisk inriktning. För utvecklingen av den praktiska metoden föreslår vi den indelning som redovisas i Böhnke-Henrichs et al. (2013), se avsnitt $3.1 \mathrm{i}$ rapporten.

Det andra steget omfattar identifiering och definiering av de maritima sektorer/aktiviteter som ska inkluderas i analysen. Även här finns det ett antal olika förslag på klassificeringar och indelningar tillgängliga, bl.a. de som förts fram bland EU:s medlemsländer (Surís-Regueiro et al. 2013) i arbetet med genomförandet av MSFD. För utvecklingen av metoden föreslår vi att den indelning som förs fram inom den Europeiska kommissionen för revisionen av annex III i MSFD används, se avsnitt 3.2 i rapporten. Det här steget identifieras också de miljöbelastningar som kan kopplas till de identifierade maritima sektorerna och aktiviteterna, den indelning av miljöbelastningar som tillämpas är hämtad från samma underlag som ovan.

I det tredje steget används de miljöbelastningar som identifierats sammanställts i det föregående steget för att identifiera berörda ekosystemtjänster.

\section{Ett praktiskt verktyg för utvärdering av de maritima aktiviteternas påverkan på ekosystemtjänsterna}

De tre övergripande steg som beskrivs i föregående stycke utgör grunden i den metod som förs fram i studien för utvärdering av de marin aktiviteternas påverkan på ekosystemtjänster som kan uppstå till följd av alternativa planeringsalternativ av marina områden. Genom metodens fokus på ett urval av strikt relevanta aktiviteter, miljöbelastningar och ekosystemtjänster avgränsas analysens omfång tidigt i processen och blir därmed mer överskådlig och lätthanterlig.

Metoden följer ett antal steg som inleds med identifiering av planeringsområde, och som via ekonomisk värdering av olika konsekvenser avslutas med 
fördelningsanalys och avvägningar mellan olika alternativa scenarier. Analysen kan tillämpas på kompletta planer med många motstående intressen, men kan också begränsas till enskilda sektorer eller aktiviteter.

Med målsättningen att beskriva förändringar i välbefinnande hos olika berörda intressentgrupper utvärderas de ekonomiska konsekvenserna av olika planeringsalternativ i termer av förändringar i tillgång och kvalitet på berörda ekosystemtjänster. I möjligaste mån beskrivs förändringar med monetära värden, exempelvis förändringar i netto-inkomster från kommersiellt fiske till följd av förändrad tillgång till fiskevatten. I andra fall kan förändringar i välbefinnande beskrivas semikvantitativt (med poängbedömningar), kvantitativt (hektar, ton etc.) eller kvalitativt (med ord). Utvärderingen kan betraktas som en utvidgad kostnadsnyttoanalys (CBA) på så sätt att den också inkluderar effekter som normalt inte omfattas av CBA, exempelvis sysselsättningseffekter och fördelningseffekter.

\section{Tillämpning av metoden på ett fiktivt fallstudieområde}

Ett fiktivt fallstudieområde i Östersjön har använts för att illustrera de olika stegen I metoden, området är beläget strax söder om Gotland och omfattar Hoburgs bank, samt Norra och Södra Mittsjöbankarna. I referensscenariet genomkorsas området av farleder både i dess norra och södra del. Miljöbelastningarna från fartygstrafiken påverkar både befintliga skyddade områden (N2000 och IBA) och lekområden för hälleflundra. I planeringsscenariet stängs den norra farleden, de skyddade områdena utvidgas samtidigt som en spridningskorridor upprättas mellan de två skyddade områdena. I tillägg görs en avgränsning för förnyelsebar energi (vindkraft) i den södra delen av området.

De fiktiva referens- och planeringsscenarierna används för att demonstrera hur metoden som förs fram i studien kan användas för att kartlägga sambanden mellan förändringar i marina aktiviteter och förändringar i miljöbelastningar, samt slutligen hur förändringarna resulterar i påverkan på tillgång och kvalitet hos de marina ekosystemtjänsterna. Demonstrationen avslutas med en diskussion om möjliga metoder för monetär ekonomisk värdering av marina ekosystemtjänster, samt hur analys av fördelningseffekter och avvägningar mellan alternativa eller motstående planeringsalternativ kan göras. 


\section{Slutsatser}

Den metod som förs fram i studien visar tydligt hur ekosystemtjänster kan inkluderas $\mathrm{i}$ processen för fysisk havsplanering. För att metoden ska bli ytterligare mer tillämplig behöver emellertid de indikatorer som förslås för utvärdering av ekosystemtjänster utvecklas vidare. Framtida studier inom området behöver bl.a. ägnas åt hur ekosystemtjänsternas indikatorer kan samordnas med de indikatorer som används inom MSFD och BSAP (HELCOM) för utvärdering av det marina miljötillståndet.

\section{Fortsatt utveckling av metoden}

Under projektets gång har ett antal förbättringsområden identifierats:

- Det system för poängbedömning av påverkan på ekosystemtjänster som tillämpas i studien är inte fullt ut anpassat för utvärdering av positiva effekter. Om negativ påverkan på en specifik ekosystemtjänst minskar till följd av åtgärder inom ett planeringsscenario, jämfört med ett referensscenario, så redovisas den positiva effekten genom tilldelning av lägre påverkanspoäng. Men i situationer då det inte från början förkommer någon negativ påverkan för en specifik ekosystemtjänst i ett referensscenario, och åtgärder i ett planeringsscenario ändå leder till en förbättring, då klarar inte poängbedömningssystemet av att beskriva den positiva effekten. Ett exempel kan vara vid utvidgning av skyddade områden, eller då spridningskorridorer mellan upprättas mellan skyddade områden. De positiva effekterna från den typen av förändringar är svåra att fånga med det nuvarande poängsystemet, de beaktas därför i nuläget endast i den del av metodiken som berör fördelningseffekter av olika planeringsalternativ.

- Ett flertal av de marina sektorerna och aktiviteterna har ett dubbelriktat förhållande till ekosystemtjänsterna. Samtidigt som de medför en miljöbelastning som påverkan tillgång och kvalitet på ekosystemtjänsterna, så är de beroende av samma ekosystemtjänster för sina ekonomiska verksamheter eller syften. Det är också vanligt med maritima aktiviteter som inte alls är beroende av marina ekosystemtjänster men som påverkar andra sektorer och aktiviteter indirekt genom sin påverkan på ekosystemtjänsterna. I den här studien har ett första steg tagits för att inkludera kartläggning och utvärdering av olika sektorers och aktiviteters beroenden av marina ekosystemtjänster. Syftet har varit att inkludera en systematisk metod för att kartlägga kopplingarna mellan miljöbelastningar från maritima aktiviteter och de kostnader samt förluster i välbefinnande som uppstår bland samma eller andra sektorer och intressentgrupper till följd av dessa. 
Även om en sådan metod har mycket att tillföra den övergripande metodiken har det av tidsskäl inte kunnat genomföras inom ramen för det nuvarande projektet.

- För att exemplifiera metoden som presenteras i den här studien används ett fiktivt planeringsunderlag från området strax söder om Gotland. För att underlätta en fortsatt utveckling av metodiken, och för att kunna göra de kompletteringar som nämns ovan, behöver metoden tillämpas och testas på ett verkligt fallstudieområde. I tillägg till de justeringar av poängbedömningssystemet som nämns ovan, skulle en sådan fallstudie också ge möjligheten till faktiska monetära värderingar av ekosystemtjänster. Även de steg som omfattar fördelningsanalys och avvägningar mellan motstående intressen, alternativa planeringsscenarier m.m., skulle då kunna testas och förfinas. 


\section{Appendix 1. CICES classification of marine ecosystem services}

Table 1: CISES classification of marine ecosystem services (version 4.3, www.cices.eu)

\begin{tabular}{|c|c|c|}
\hline CICES Service Section & CICES division & $\begin{array}{l}\text { CICES Group and Class (as relevant for marine } \\
\text { ecosystems) }\end{array}$ \\
\hline \multirow[t]{3}{*}{ Provisioning services. } & Nutrition. & Fish, shellfish, algae and their outputs for used for food. \\
\hline & Materials. & $\begin{array}{l}\text { Fibres and other material from plants, algae, and animals } \\
\text { for direct use or processing (including agricultural use } \\
\text { and genetic materials from biota). }\end{array}$ \\
\hline & Energy. & Biomass based energy sources (e.g. algae for energy). \\
\hline \multirow[t]{3}{*}{ Regulating and maintenance. } & $\begin{array}{l}\text { Meditation of waste, toxics } \\
\text { and other nuisances. }\end{array}$ & $\begin{array}{l}\text { Mediation by biota and ecosystems (their ability to } \\
\text { remove or store pollutants, e.g. bioremediation by } \\
\text { organisms, filtration, storage and accumulation. }\end{array}$ \\
\hline & Mediation of flows & $\begin{array}{l}\text { Mass stabilization and control of erosion rates, flood } \\
\text { protection (etc.). }\end{array}$ \\
\hline & $\begin{array}{l}\text { Maintenance of physical, } \\
\text { chemical and biological } \\
\text { conditions. }\end{array}$ & $\begin{array}{l}\text { Lifecycle maintenance, habitat and gene pool protection } \\
\text { (dispersal and maintenance of nursery population and } \\
\text { habitats, gene pool protection); pest and disease control; } \\
\text { decomposition and fixing processes; chemical condition } \\
\text { of water; climate regulation (by reduction of greenhouse } \\
\text { gas concentration). }\end{array}$ \\
\hline \multirow[t]{2}{*}{ Cultural. } & $\begin{array}{l}\text { Physical and intellectual } \\
\text { interactions with biota and } \\
\text { ecosystems, and seascapes. }\end{array}$ & $\begin{array}{l}\text { Experimental and physical use (e.g. many activities of } \\
\text { recreation, swimming, diving, leisure fishing, etc.), } \\
\text { scientific, educational, heritage, entertainment, and } \\
\text { aesthetic interactions. }\end{array}$ \\
\hline & $\begin{array}{l}\text { Spiritual, symbolic and other } \\
\text { interactions with biota, } \\
\text { ecosystems, and seascapes. }\end{array}$ & $\begin{array}{l}\text { Symbolic, sacred and/ or religious, as well as existence } \\
\text { and bequest values; }\end{array}$ \\
\hline
\end{tabular}

Source: Hasler et al. 2016. 



\section{Appendix 2. Example of identification and selection of ecosystem services classification for the Gulf of Finland (Baltic Sea)}

In an ad hoc test for the identification of suitable ecosystem services classification for the benthic habitats in the Gulf of Finland (GoF), Baltic Sea, an expert group from the Finnish Environment Institute's Marine Research Centre compared three modified classification systems (based on the Economics of Ecosystems and Biodiversity - TEEB, Millennium Ecosystem Assessment - MEA and the Common International Classification of Ecosystem Services - CICES; Table 1), and proposed an adapted local ecosystem services classification (for benthic habitats only) for the Gulf of Finland (Table A2.2). ${ }^{8}$

The first step was to compare iteratively the three proposed ecosystem services classification systems (Table 1), and to select a feasible combination of those, using the expert knowledge of the benthic ecosystem structure and functioning in the GoF (Table 2). Second step was to scrutinize those, and to evaluate based on existing knowledge of available information and data, which of the services are relevant for the GoF, or if there is any data or information of those services (Table 3 ).

The expert group concluded that some of the ecosystem services identified in the Table A2.1.; genetic resources, medicinal resources, ornamental resources, air purification (combined with Climate regulation), Regulation of water flows, Gene pool protection, Spiritual experience (sensu Böhnke-Henrichs et al. 2013) are either not relevant for the benthic habitats in the Gulf of Finland or there is none or very little information of those, which do not allow identification of the presence of magnitude of these services. The remaining ecosystem services, that were considered relevant for the Gulf of Finland, are listed in Table 3.

\footnotetext{
${ }^{8}$ Participating experts from the Finnish Environment Insitute: Anna-Stiina Heiskanen, Samuli Korpinen, Harri Kuosa, Juho Lappalainen, Marco Nurmi Heikki Peltonen, Laura Uusitalo, Riku Varjopuro and Markku Viitasalo.
} 
Table 1: Comparison of three different options for the classification of the ecosystem services (ES) for the benthic ecosystem of the Gulf of Finland, Baltic Sea

\section{TEEB (modified)}

Provisioning services. Sea food.

(Sea Water) not relevant in benthos.

Raw materials.

Genetic resources

Medicinal resources.

Ornamental resources.

\begin{tabular}{|c|c|}
\hline \multirow[t]{7}{*}{ Regulating services. } & Air purification. \\
\hline & Climate regulation. \\
\hline & $\begin{array}{l}\text { Disturbance prevention or } \\
\text { moderation. }\end{array}$ \\
\hline & Regulation of water flows. \\
\hline & Waste treatment. \\
\hline & Coastal erosion prevention. \\
\hline & Biological control. \\
\hline \multirow{2}{*}{$\begin{array}{l}\text { Habitat Services } \\
\text { (regulating). }\end{array}$} & Lifecycle maintenance. \\
\hline & Gene pool protection. \\
\hline \multirow{6}{*}{$\begin{array}{l}\text { Cultural and amenity } \\
\text { services. }\end{array}$} & Recreation and leisure. \\
\hline & $\begin{array}{l}\text { Inspiration, culture, arts and } \\
\text { design. }\end{array}$ \\
\hline & Cultural heritage and identity. \\
\hline & Aesthetic information. \\
\hline & $\begin{array}{l}\text { Information for cognitive } \\
\text { development. }\end{array}$ \\
\hline & Spiritual experience. \\
\hline
\end{tabular}

Food provision.

Air quality and climatic regulation.

Disturbance and hazard regulation.

\section{Nutrient cycling}

Water quality regulation and bio-remediation of waste.

Raw materials.
Game.

Fish and crayfish.

Clean water.
Reared animals.
Water filtration.

Carbon cycle.

Nutrient retention

Mediation of waste and
Photosynthesis,
hemosynthesis, and
primary production

Reproduction and nursery. Nursery habitats.

Maintenance of biodiversity.

Leisure, recreation and

cultural value.

Recreation.

Nature tourism.

Arts and popular culture.

Nature related heritage.

Landscape.

Feel good or warm glow.

Cognitive value.

Source: The evaluated classification systems were 1) TEEB: Böhnke-Henrichs et al. 2013 (based on modified TEEB), 2) MEA: Galparsoro et at. 2014 (based on ES categories identified by Salomidi et al. (2012) and adapted from the MEA), and the 3) CICES: ecosystem service classification system modified for Finland (available at www.biodiversity.fi) which is based on CICES (Jäppinen and Heliölä, 2015). 
Table 2: An adapted ecosystem services typology suggested for the benthic habitats in the Gulf of Finland, Baltic Sea, identified by an expert group

\section{Category \\ Ecosystem service}

Provisioning services.

Sea food.

(Sea water) not relevant in benthos.

Raw materials.

Genetic resources.

Medicinal resources.

Ornamental resources.

Regulating services. Air purification.

Climate regulation.

Disturbance prevention or moderation.

Regulation of water flows.

Nutrient regulation.

Waste treatment.

Coastal erosion prevention.

Biological control.

Habitat services (Regulating services). Lifecycle maintenance.

Gene pool protection.

Cultural services.

Recreation and leisure.

Inspiration and Culture, Art and Design.

Cultural heritage and identity.

Aesthetic information.

Information for cognitive development.

Spiritual experience.

Note: Participating experts from the Finnish Environment Insitute: Anna-Stiina Heiskanen, Samuli Korpinen, Harri Kuosa, Juho Lappalainen, Marco Nurmi Heikki Peltonen, Laura Uusitalo, Riku Varjopuro and Markku Viitasalo. 


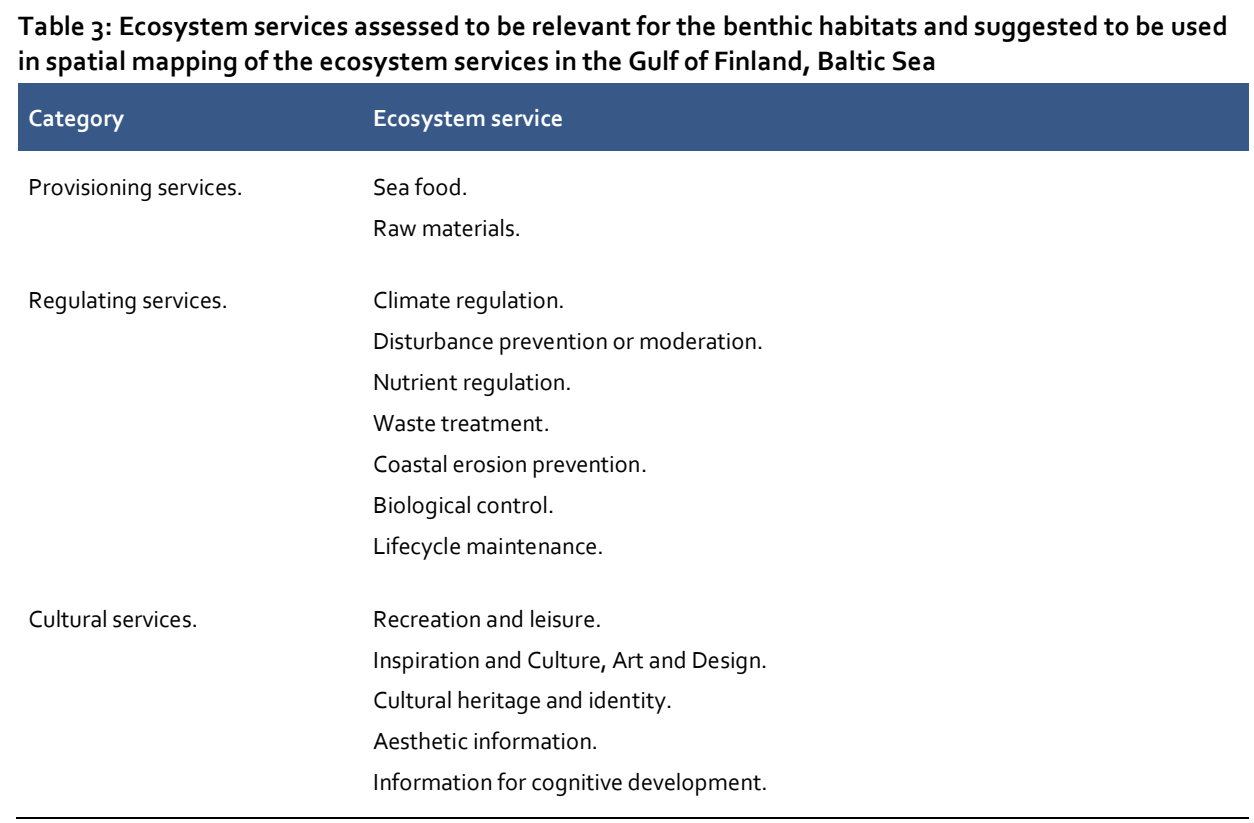

Note: Expert group evaluation.

The expert group concluded that the minimum background information necessary for identification of relevant ecosystem services and for a proper mapping of benthic ecosystem services include:

- Reliable habitat maps, with sufficient resolution (depending on the scale of the region in interest).

- Information/ or data on the state of the habitats, as well as on water quality.

- Information of species distribution at last for dominating, habitat forming, and keystone species.

- Information / data on the distribution of the populations or productivity of species providing seafood, including pelagic fish.

- Information/ data of the human activities (utilizing ecosystem services, or producing pressures). 
Appendix 3. Links between pressures and marine ecosystem services

Table 1: Links between pressures and marine ecosystem services

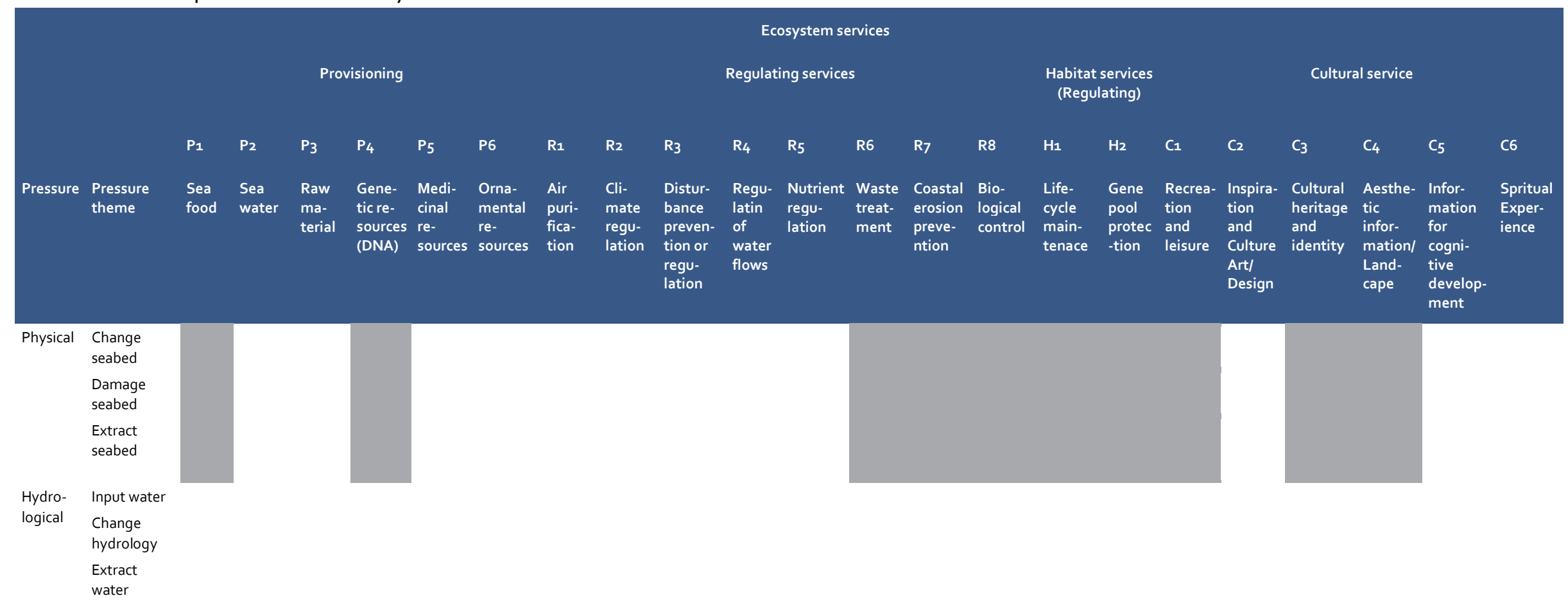




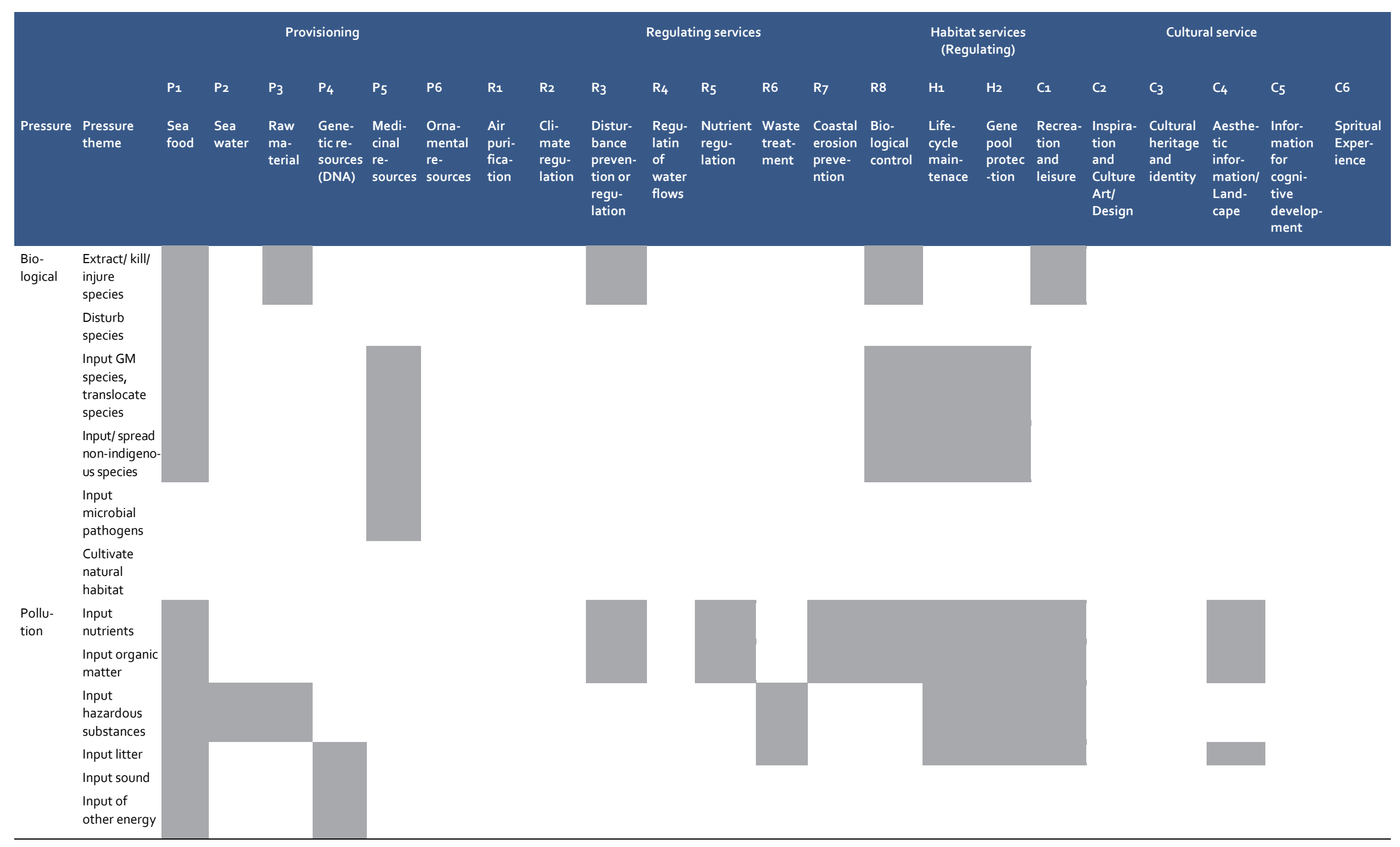





\section{Appendix 4. Template for recording results from impact analysis}

Table 1: Template for recording results from ecosystem services impact assessment

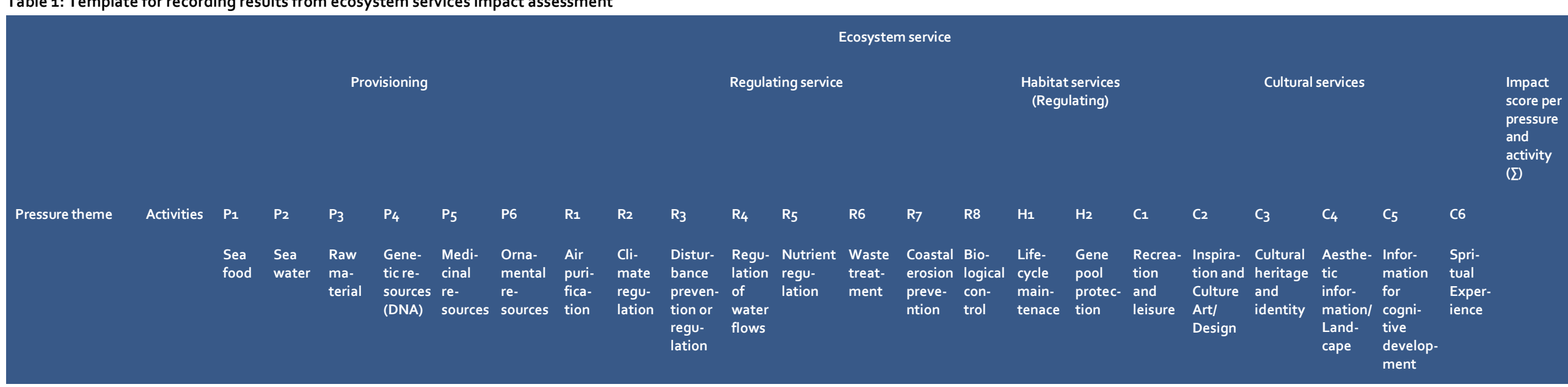

Change seabed Damage seabed

Extract seabed

Input water

Change hydrology

Extract water

Extract/ kill/injure

species

Disturb species

Input GM species,

translocate species

Input/spread non-

indigenous species 


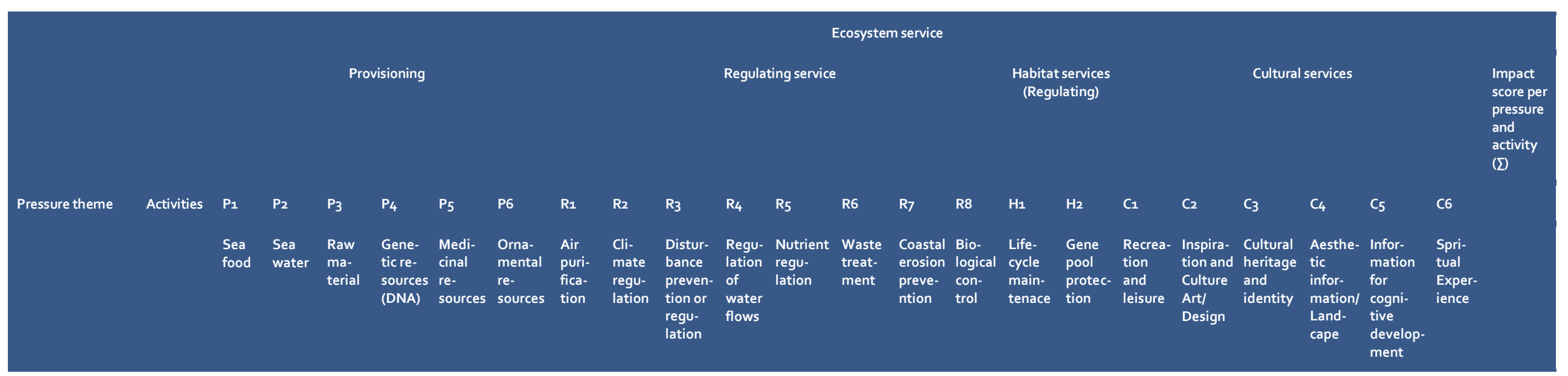

Input microbial

pathogens

Cultivate natural

habitat

Input nutrients

Input organic matter

Input hazardous

substances

Input litter

Input sound

Input of other

energy

Impact score per

ecosystem service

(I) 



\section{Appendix 5. Template for compiling overall impact for each affected individual activity in a specific planning scenario}

Table 1: Example template for summarizing and comparing analysis result for different maritime activities

\begin{tabular}{|c|c|c|c|c|c|c|c|c|c|c|c|c|c|}
\hline & \multicolumn{12}{|c|}{ Ecosystem services } & 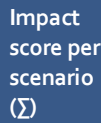 \\
\hline & \multicolumn{7}{|c|}{ Provisioning services } & \multicolumn{2}{|c|}{$\begin{array}{l}\text { Habitat services } \\
\text { (Regulating) }\end{array}$} & \multicolumn{3}{|c|}{ Cultural services } & \\
\hline & $P_{1}$ & $\mathbf{P}_{2}$ & $P_{3}$ & $\mathrm{P}_{4}$ & R6 & R7 & R8 & $\mathrm{H}_{1}$ & $\mathrm{H}_{2}$ & $\mathrm{C}_{1}$ & $\mathrm{C}_{3}$ & $\mathrm{C}_{4}$ & \\
\hline Activities & $\begin{array}{l}\text { Sea } \\
\text { food }\end{array}$ & $\begin{array}{l}\text { Sea } \\
\text { water }\end{array}$ & $\begin{array}{l}\text { Raw } \\
\text { material }\end{array}$ & $\begin{array}{l}\text { Genetic } \\
\text { re- } \\
\text { sources } \\
\text { (DNA) }\end{array}$ & $\begin{array}{l}\text { Waste } \\
\text { treat- } \\
\text { ment }\end{array}$ & $\begin{array}{l}\text { Coastal } \\
\text { erosion } \\
\text { preven- } \\
\text { tion }\end{array}$ & $\begin{array}{l}\text { Bio- } \\
\text { logi- } \\
\text { cal } \\
\text { con- } \\
\text { trol }\end{array}$ & $\begin{array}{l}\text { Life- } \\
\text { cycle } \\
\text { main- } \\
\text { ten- } \\
\text { ance }\end{array}$ & $\begin{array}{l}\text { Gene } \\
\text { pool } \\
\text { protec- } \\
\text { tion }\end{array}$ & $\begin{array}{l}\text { Recrea- } \\
\text { tion } \\
\text { and } \\
\text { leisure }\end{array}$ & $\begin{array}{l}\text { Cultural } \\
\text { heritage } \\
\text { and } \\
\text { identity }\end{array}$ & $\begin{array}{l}\text { Aesthe- } \\
\text { tic } \\
\text { infor- } \\
\text { mation } \\
\text { /Land- } \\
\text { scape }\end{array}$ & \\
\hline
\end{tabular}





\section{Appendix 6. Template for compiling overall impacts on ecosystem services from the relevant planning scenarios}

Table 1: Example template for summarizing and comparing analysis result for different planning scenarios

\begin{tabular}{|c|c|c|c|c|c|c|c|c|c|c|c|c|c|}
\hline & \multicolumn{12}{|c|}{ Ecosystem services } & \multirow{4}{*}{$\begin{array}{l}\text { Impact } \\
\text { score per } \\
\text { scenario } \\
(\Sigma)\end{array}$} \\
\hline & \multicolumn{7}{|c|}{ Provisioning services } & \multicolumn{2}{|c|}{$\begin{array}{l}\text { Habitat services } \\
\text { (Regulating) }\end{array}$} & \multicolumn{3}{|c|}{ Cultural services } & \\
\hline & $\mathrm{P}_{1}$ & $\mathbf{P}_{2}$ & $P_{3}$ & $\mathrm{P}_{4}$ & R6 & R7 & R8 & $\mathrm{H}_{1}$ & $\mathrm{H}_{2}$ & $\mathrm{C}_{1}$ & $\mathrm{C}_{3}$ & $C_{4}$ & \\
\hline Activities & $\begin{array}{l}\text { Sea } \\
\text { food }\end{array}$ & $\begin{array}{l}\text { Sea } \\
\text { water }\end{array}$ & $\begin{array}{l}\text { Raw } \\
\text { material }\end{array}$ & $\begin{array}{l}\text { Genetic } \\
\text { re- } \\
\text { sources } \\
\text { (DNA) }\end{array}$ & $\begin{array}{l}\text { Waste } \\
\text { treat- } \\
\text { ment }\end{array}$ & $\begin{array}{l}\text { Coastal } \\
\text { erosion } \\
\text { preven- } \\
\text { tion }\end{array}$ & $\begin{array}{l}\text { Bio- } \\
\text { logi- } \\
\text { cal } \\
\text { con- } \\
\text { trol }\end{array}$ & $\begin{array}{l}\text { Life- } \\
\text { cycle } \\
\text { main- } \\
\text { ten- } \\
\text { ance }\end{array}$ & $\begin{array}{l}\text { Gene } \\
\text { pool } \\
\text { protec- } \\
\text { tion }\end{array}$ & $\begin{array}{l}\text { Recrea- } \\
\text { tion } \\
\text { and } \\
\text { leisure }\end{array}$ & $\begin{array}{l}\text { Cultural } \\
\text { heritage } \\
\text { and } \\
\text { identity }\end{array}$ & $\begin{array}{l}\text { Aesthe- } \\
\text { tic } \\
\text { infor- } \\
\text { mation } \\
\text { /Land- } \\
\text { scape }\end{array}$ & \\
\hline \multicolumn{14}{|l|}{$\begin{array}{l}\text { Reference } \\
\text { scenario }\end{array}$} \\
\hline \multicolumn{14}{|l|}{$\begin{array}{l}\text { Alternative } \\
\text { scenario }\end{array}$} \\
\hline $\begin{array}{l}\text { Impact } \\
\text { change }(\Sigma)\end{array}$ & & & & & & & & & & & & & \\
\hline
\end{tabular}





\section{Appendix 7. Marine spatial planning in the Nordic countries}

Below, the legislation and different prerequisites for MSP are reviewed for the Nordic as well as other countries surrounding the Baltic Sea.

\section{Norway}

Norway is part of the OSPAR convention, but not a member of the EU and hence has not adopted EU's MSFD or the MSP directive.

The marine planning in the coastal sea areas and the EEZ of Norway are controlled by two different mechanisms. Activities in the coastal zone (within one nautical mile from the baseline) are regulated by the Planning and Building Act. The activities in the EEZ, in contrast, are managed via "Integrated Ecosystem-based Management Plans" (below, IEMP) that have been prepared for three Norwegian sea areas, the North Sea, the Norwegian Sea and the Barents Sea (including Svalbard sea area).

In Norway, work on the IEMPs is coordinated by an inter-ministerial Steering Committee headed by the Ministry of Climate and Environment (KLD). In addition, expert and advisory groups have been established to implement the management plans consisting of all involved directorates and their research institutions. A public consultation process also takes place, using conferences and public hearings, and the responses are assessed (Figure 1).

Figure 1: Organization of the marine spatial planning process in Norway

Norwegian marine management plans

Organization

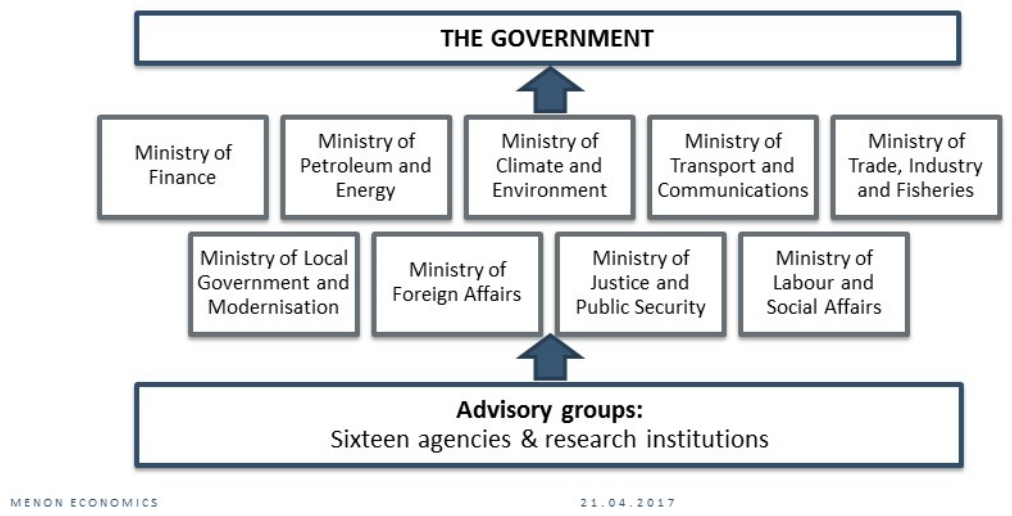

Source: Norwegian Ministry of Climate and Environment. 
The results of the consultation process are used in the preparation of the Norwegian White Paper, which laid the foundation for integrated ecosystem based management of coastal and marine areas (called "Protecting the Riches of the Sea") in 2001-02.

In addition to the Norwegian Ministry of Climate and Environment, the Ministry of Transport and Communications has responsibility for "coastal management, the marine environment and port and sea transport policy" in Norwegian waters.

In the EEZ area, the main goal of the IEMPs is to allow for sustainable use while ensuring the health of the ecosystem. The goal is that marine spatial planning is not carried out as a separate process, but as a tool for the ecosystem-based, integrated approach to the management of marine areas.

The management plans set an overall framework for both existing and new activities in the EEZ, and facilitates the co-existence of different industries, particularly the fisheries industry, maritime transport and petroleum industry. The health of the ecosystem is secured through designated marine protected areas, which are legislated through Marine Resources Act and Nature Diversity Act. Valuable and Vulnerable sea areas have been identified based on their biodiversity or biological production (e.g. spawning areas or breeding sites).

The IEMP however have limited legislative authority. Each sector, including shipping, fisheries, aquaculture and petroleum industries, are managed separately through specific legislations and dedicated ministries. Despite this, the plans have already contributed to changes in the routing system for all non-domestic voyages of tankers and larger ships. They have been moved further from the coast, in order to reduce the damage to the coastal areas caused by eventual shipping accidents.

Figure 2: The process behind the integrated ecosystem based management plan for the Norwegian Sea

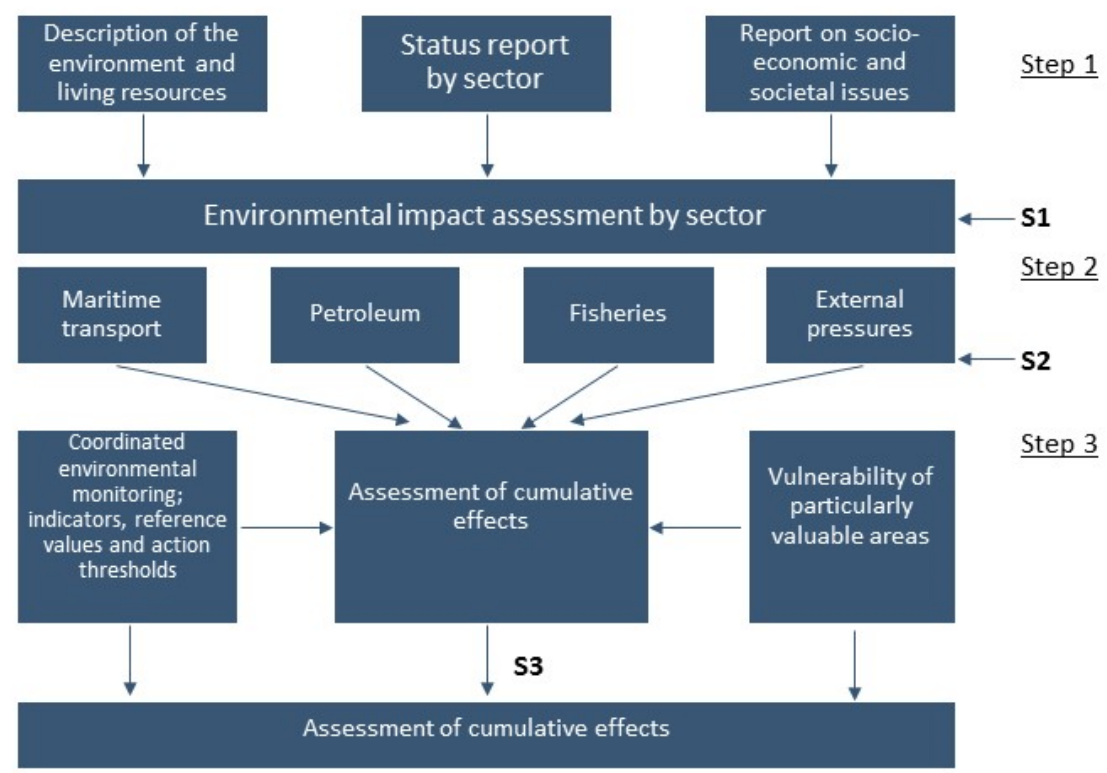


In the coastal zone (within one nautical mile from the baseline) the planning is administered by regional and local authorities in counties and municipalities. Counties are responsible for preparing regional plans also for the coastal areas. From 2010, the counties are also the regional responsibility for one of the main industries in Norwegian sea area, the aquaculture, including the extensive salmon farming.

\section{Sweden}

In Sweden, new MSP-legislation entered into force on September 2014. Since July 2015 a Government Ordinance is detailing the geographical boundaries, process, responsibilities, objectives and the content of the marine spatial plans. In 2015, the Government also adopted a Swedish national maritime strategy. The vision is based on three equal perspectives: A balanced marine environment, Competitive maritime industries and Attractive coastal areas. The forthcoming marine spatial plans are considered important instruments in balancing these different needs in the Swedish marine areas.

In practice, the Swedish Environmental Code (1998:808) and the Plan and Building Act (2010:900) constitute the legal base for marine spatial planning. According to the Environmental Code there shall be shall be three marine spatial plans, each adopted by the Government: Bothnian Bay, Baltic Sea, Western Waters (Skagerrak/Kattegat) covering the area one nautical mile from the baseline seawards, including the EEZ. The plans do not cover privately owned sea areas, however.

The marine spatial plans reflect the state's overall view of how the marine areas are to be managed and how public interests should be taken into account. The marine spatial plans also specify areas of national interest. These include areas of specific cultural heritage and values, nature protection and recreation, as well as areas of specific interest for different sectors, such as shipping, energy production and commercial fisheries.

The Marine Spatial Planning Ordinance (2015:400) regulates the process of the marine spatial planning. According to the Ordinance, SwAM (Swedish Agency for Marine and Water Management) develops the proposals for marine spatial plans with the help of county boards and national authorities. The regions, counties and municipalities participate in the proposal process and SWAM shall also secure coordination of the plans with those of other countries.

SwAM shall apply an ecosystem approach in its work. The main focus of the planning is that marine resources should be used in a way that allows maritime industries to develop and grow while preserving and restoring ecosystems. The marine spatial plans shall contribute to achieving and maintaining a good marine status according to the EU Marine Strategy Framework Directive.

In addition to the Environmental Code, the Plan and Building Act (2010:900) regulates the spatial planning in Sweden. The Act includes guidance on how municipalities should plan their usage of their marine areas. The plan is guiding, but not legally binding; it indicates the municipalities' intentions about the future development. This however means that there is some geographical overlap between 
the municipal comprehensive plans (Plan and Building Act) and the national marine spatial plans (the Environmental Code).

In addition to the Environmental Code and the Plan and Building Act, Sweden is in its planning bound to several international conventions and legal acts such as UNCLOS, Espoo Convention, CBD, IMO Resolutions and conventions, HELCOM recommendations and the EU directives.

\section{Finland}

Spatial planning in the sea areas of Finland is implemented through national spatial planning procedures and principles. The Land Use and Building Act is the most important act to steer land use, spatial planning and construction. According to the Act, land use planning is implemented on Territorial Sea as well as on land. The UNCLOS Law of the Seas is implemented in national legislation on Exclusive Economic Zone 2004.

According to the planning principles in Finland, the Government first defines National Land Use Guidelines, which should be taken into account throughout the country in all land use decisions and land use planning. Then, regional land use plans, that include the territorial sea areas, are drafted by eight coastal regional councils. These general plans set out medium-term and long-term objectives for regional land use strategies that guide regional development and steer decisions on issues that are of a trans-municipal or regional nature. Regional land use plans are legally guiding the local master plans that are approved by local authorities. In drawing up a regional land use plan, special attention is given - in addition to the regional and community structure of the region and operating conditions for the businesses - also to ecological sustainability of land use, environmentally and economically sustainable transport and services, sustainable use of water and extractable land resources, protection of landscape, natural values, and cultural heritage, and sufficient availability of areas suitable for recreation. The local master plan, in turn, is legally guiding the most Local detailed plans that are approved by the local authorities (Figure 3). Local master plans and especially the local detailed plans are very detailed and rarely include issues regarding the sea area. 


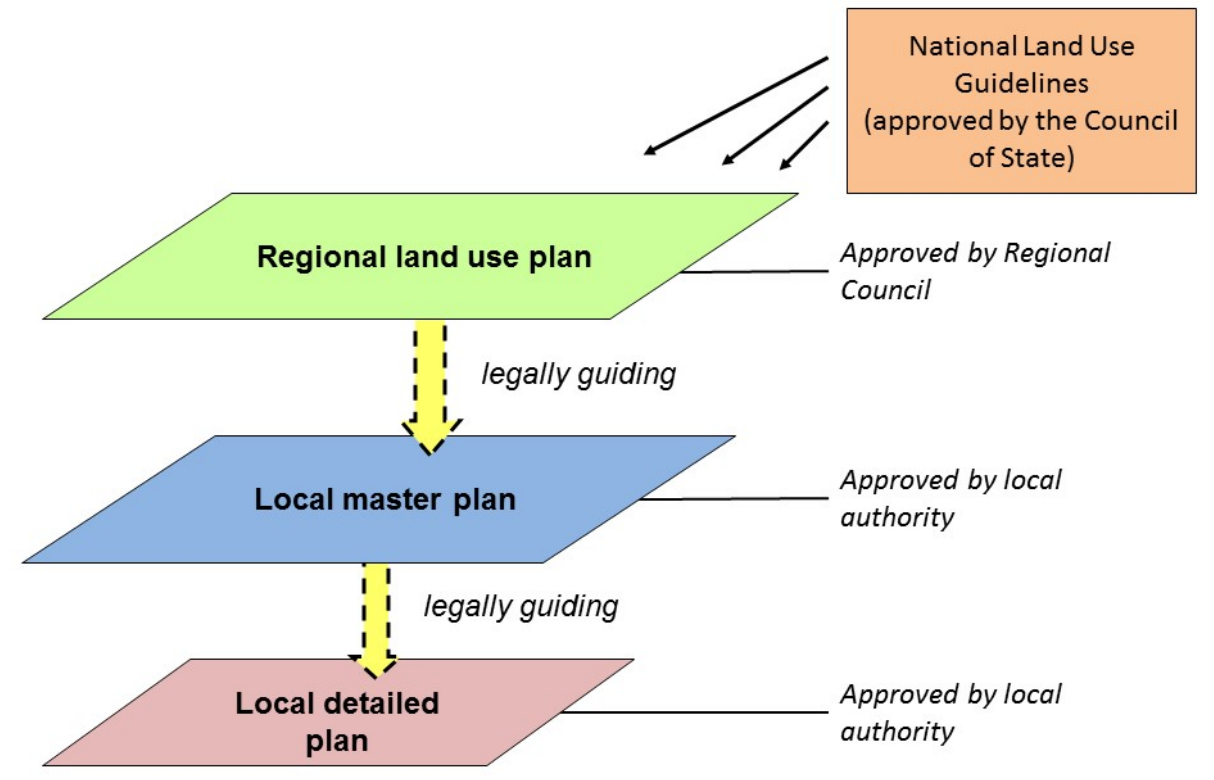

The maritime spatial planning directive was transposed in to Finnish law in 2016. MSP regulations are given as a part of the Land Use and Building Act. Nonetheless, maritime spatial planning is not part of the land use planning system of Finland. Maritime spatial plans are general, non-binding plans drafted and approved by the Regional Councils. Eight Coastal Regional Councils are in charge of drafting maritime spatial plans on Territorial waters and on EEZ by March 2021. There will be three plans; one for the Bothnian Sea by Regional Councils of Lappi, Pohjois-Pohjanmaa, Etelä-Pohjanmaa and Pohjanmaa, one for the South-Western part of Finnish Coast by Regional Councils of Satakunta and Varsinais-Suomi and the third for the Gulf of Finland by the Regional Council of Uusimaa and Kymenlaakso.

The plans should promote sustainable development of marine areas and the sustainable use of marine resources. Energy sectors at sea, maritime transport, the fisheries and aquaculture sectors, conservation, protection and improvement of the environment and nature, tourism and recreational use of maritime areas should be especially viewed among other activities and reconciled. When drafting a plan special attention should be paid to the characteristics of the sea area and to the land -sea interaction. Communication and participation is highlighted throughout the planning process, and Regional Councils are expected to engage stakeholders and work together between each other in drafting the plans. Ministry of the Environment will develop and guide maritime spatial planning and be in charge for of cooperation with neighbouring countries.

Hence formal maritime spatial plans according to the maritime spatial planning directive have not been put up yet. Recently (in 2015), the first regional land use plan, where also the marine area was fully considered, was drafted and ratified for the 
Kymenlaakso Region (south-eastern Finland). The plan addressed issues concerning the marine strategy and water framework directives, maritime spatial planning directive and ecosystem based planning goals of the European Union. The regional plan does not cover the EEZ, but is a first attempt at integrated spatial planning of any larger sea area in Finland.

The Kymenlaakso regional plan aimed to strengthen the region's marine area's nature, cultural heritage, natural and ecosystem resources use as well as the shipping, military and tourism sectors. Known environmental risks such as eutrophication, seafaring accidents and sedimentary pollution were recognized. Importantly, for the first time, information on valuable underwater species and habitats and protected areas were taken into account. This allowed identifying areas where destructive activities, such as dredging and dumping of dredged material cause minimum damage on the underwater marine life.

Figure 4: A detail of the Kymenlaakso regional plan south of Kotka city and harbour. Light blue colour is depicting the sea

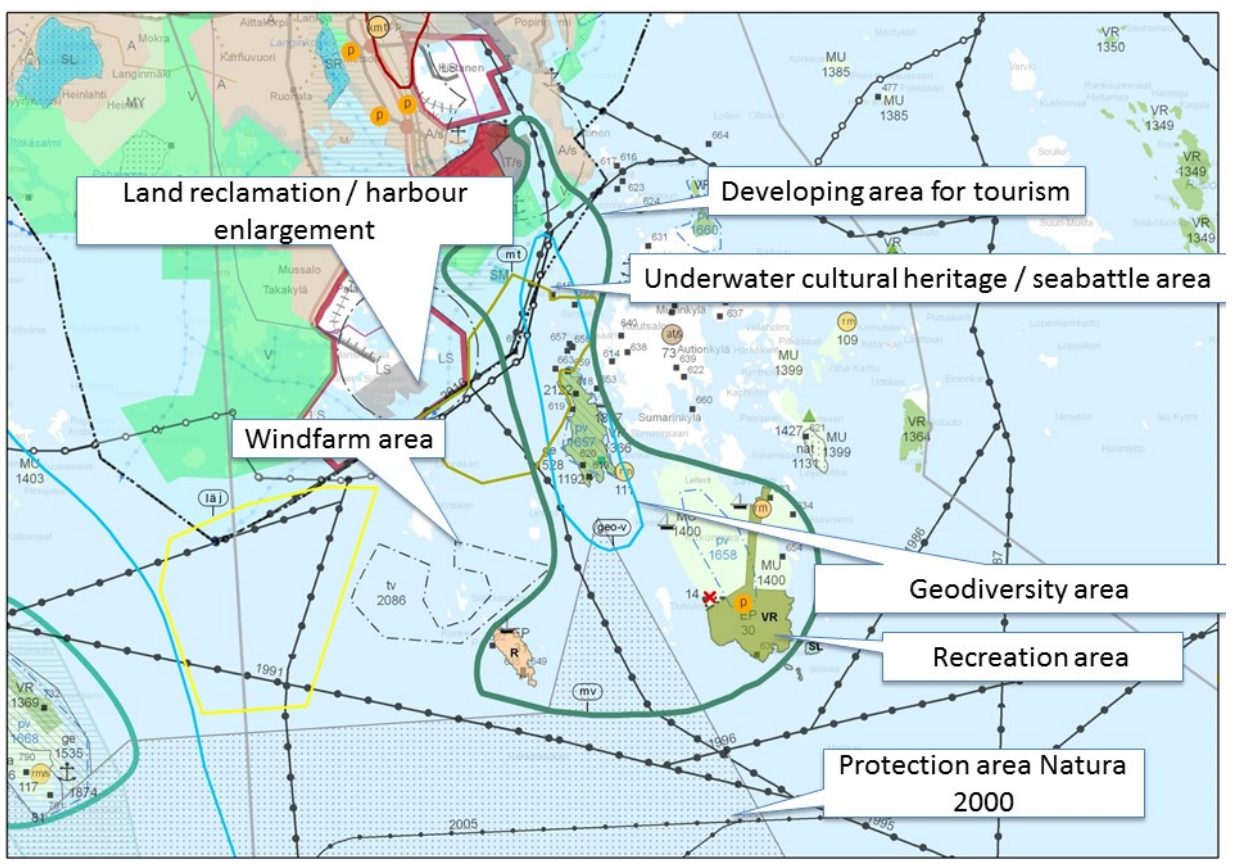

Hence, marine ecosystem services have not been explicitly taken into account in spatial planning in Finland. Taking into account marine ecosystem components, cultural heritage and other underwater resources, as well as possibilities for recreation (as in Kymenlaakso regional plan), provide a foundation for that, too. Full consideration of ecosystem services in spatial planning will however require that their spatial distribution will be mapped and assessed (cf. http://biodiversity.europa.eu/maes).

Åland is an autonomous region of Finland with responsibility for planning its own territorial waters. The legislation most relevant for marine spatial planning on the islands are the Planning and building act from 2008 and the Water Act from 1996, other important policies are the Water Framework Directive (WFD) and the Marine Strategy 
Framework Directive (MSFD). In a fashion similar to Sweden, the planning monopoly is assigned to the 16 municipalities on the islands. Åland is facing a number of challenges, e.g. the complexity of ownership in private waters closer to the shoreline, the lack of legislation on leasing or using of public waters, an increasing amount of shipping and different regulations applying in surrounding countries and shoreline protection. In order to adress these challenges, the cross municipal coordination need to be improved both with regards to the outer waters and to coastal management (Morf et al., 2013).

\section{Denmark}

Establishment of Denmark's first national maritime spatial plan was initiated in January 2017. Under the auspices of the Act on Maritime Spatial Planning of 8th June 2016, the planning process shall cover five main maritime activities (energy production, fisheries and aquaculture, shipping, minerals extraction and natural resources protection) with the possibility of also including sustainable tourism and recreative activities. The plan shall extend from the coastline to the EEZ.

The Act on Maritime Spatial Planning supplements existing sectoral regulation, including the Marine Environment Protection Act, the Raw Materials Act, the Subsoil Act, the Continental Shelf Act, the Electricity Supply Act, the Harbor Act, the Act on Safety at Sea and the Fishery Act. Through these, activities on marine areas and resources are regulated and managed by different authorities. The coming national Maritime Spatial Plan will provide a comprehensive vision of the usage of sea space based on input from the relevant authorities and stakeholders from the affected sectors.

The Act on Maritime Spatial Planning tasks the Danish Maritime Authority to establish the national maritime spatial plan in collaboration with relevant authorities and stakeholders by 31st March 2021.

The Faroe Islands, an autonomous country within the Kingdom of Denmark, currently have no legal instrument in place for marine spatial planning. The authorities on the islands do however see the need for a balanced and holistic approach to planning of the coastal and marine areas and are considering the ecosystem services concept as a way to connect the environmental concerns with the needs of e.g. fisheries and recreational activities (Morf et al., 2013). The Faroe Island authorities are about to initiate an update of the physical planning on land. The update will result in an extension of the existing plans to also include coastal and marine areas.

Similarly, the second autonomous part of the Kingdom of Denmark, i.e. Greenland, lacks an established marine spatial planning. The intention on Greenland is to apply an ecosystem-based approach to the management of coastal and marine areas and three pilot projects has been initiated to start the process (Morf et al., 2013). The marine areas covered by the projects have been identified as particularly sensitive based on biodiversity of marine mammals and birds, as well as fish recruitment. The authorities on Greenland are investigating further available options to complement the management and strengthen the protection of the marine areas. 


\section{Iceland}

In August 2014, the minister for the Environment and Natural Resources appointed a committee to draft a bill for a new law on maritime spatial planning. The committee delivered a draft proposal in November 2016 and it's review process was finalized in December 2016. The minister plans to submit the bill to Althingi (the Icelandic parliament) in spring 2017.

The draft proposal is based on the National Planning Strategy 2015-2026. This includes that the national planning strategy will be the platform for a general policy on spatial planning within the Icelandic EEZ. The draft proposal also describes how the national planning strategy shall be implemented in a regional plan for marine and coastal areas and the administrative structure for making such a regional plan.

\section{Marine Spatial Planning in the other Baltic Sea countries}

\section{Germany}

Germany has already put maritime spatial plans for both the EEZ areas and for the territorial sea. The Spatial Planning Legislation aims at achieving a balanced structure of settlements and open landscapes as well as the ecosystem, avoiding uncontrolled development and maintaining efficient infrastructures. The spatial plans for the German EEZ determine legally binding targets and guiding principles for the economic and scientific use of the sea areas, for ensuring safety and efficiency of maritime traffic and as well for the protection of the marine environment.

The national legal base for MSP in the EEZ is the Spatial Planning Act (2004). It is currently under revision - mainly because of the EU MSP Directive's requirements for applying the ecosystem approach and for the need of taking into account the land-sea interactions as well as transboundary consultation. The Federal Ministry of Transport and Digital Infrastructure (BMVI) is responsible for setting up maritime spatial plans in Germany.

The work is undertaken in the framework of UNCLOS and other international and European legislation, such as EU directives, IMO regulations, MARPOL, VASAB Long Term perspective and HELCOM Baltic Sea Action Plan.

The Maritime Spatial Plans for the EEZ areas of the Baltic Sea and the North Sea have been set into force in 2009. The Plans consider especially the spatial allocation of (1) shipping, (2) pipelines and cables, (3) marine research and (4) energy production (especially wind energy). Broad participation of the public and various stakeholders has been promoted along the process.

As for the territorial seas of Germany, MSP follows the spatial planning principles and laws of the respective federal states. In the Baltic Sea the territorial sea falls under the jurisdiction of two states, i.e., Schleswig-Holstein (bordering Denmark) and Mecklenburg-Vorpommern (bordering Poland). 


\section{Poland}

Polish sea areas are managed by the Ministry of Maritime Economy and Inland Navigation, which acts as owner of all polish sea areas. The operative administration of the sea areas is carried out by three regional Maritime Offices (in Gdynia, Slupsk and Szczecin) under this ministry. The Maritime Offices are responsible for preparation of maritime spatial plans. Other types of permits and licenses for the use of the sea space (e.g. construction permits, mining licenses, water law permits) are issued by other public authorities, but only after consulting the relevant organ of the maritime administration.

The main legal act is "The Act on Sea Areas of Poland and Maritime Administration", in which regulations concerning maritime spatial planning are placed. They regulate planning of the sea space and of a neighbouring terrestrial strip called the "coastal belt". The EU MSP Directive has also been implemented by adopting changes in this Act in 2015.

The maritime spatial plans prepared by the Maritime Offices determine the uses of the sea areas, with relevant prohibitions and limitations, directions for development of maritime transport and technical infrastructure, and areas for protection of environment and cultural heritage.

Three pilot maritime spatial plans exist in Poland, namely those for the western part of the Gulf of Gdansk, Pomeranian Bight/Arkona basin, and the Southern Middle Bank. The pilot plans are not legally binding. 6.1 Preparation of a legally binding (regulatory) maritime plan in scale 1:200,000 for all Polish sea areas (except for ports, the Szczecin Lagoon and the Vistula Lagoon) started in 2013. The first stage of the preparation of the plan was completed in 2015.

Poland is also bound in its marine management by several international conventions and legal acts such as UNCLOS, Espoo Convention, Bonn Convention, CBD, IMO and HELCOM (HELCOM 2013) as well as EU directives.

\section{Estonia}

As of 1st July 2015 Estonia has a new Planning Act which also regulates maritime spatial planning. Until that, maritime spatial planning was based on terrestrial planning and it was done on county level as pilot projects. According to the new Planning Act, maritime spatial planning will be carried out on state level, as an extension to the national plan. The maritime spatial plan will cover both the territorial waters and the EEZ. Possible subjects to be covered in the MSP are infrastructure (energy, transport), providing sustainable use of fisheries, taking into account the MPAs and putting down measures for maintaining the good and healthy status of the environment.

The maritime spatial plan will be a long-term national level plan, which will give guidelines to different institutions in charge of allowing the use of marine areas for different purposes, such as offshore energy, shipping etc.

Pilot maritime spatial plans have been prepared (cf. http://www.baltseaplan.eu/) for the area around Hiiu Island and for the Pärnu Bay area. The main objective of the plans was to define the long-term uses of the assigned marine area through a public process, taking into account the different economic, social, cultural and environmental interests 
and needs. There are three different areas determined in the plan: general use areas, priority use areas and restriction areas. In the Hiiu plan three different areas were designated: (1) general use areas, that are open for any use as long as it is in accordance with the law; (2) priority use areas in which one use, such as aquaculture, has a priority over other uses; and (3) restriction areas, where only one use, such as marine protection, is allowed. In the Pärnu Bay, which is a more densely populated area than the Hiiu area, emphasis was given to stakeholder participation. A balanced use scenario was chosen, featuring, e.g., sustainable fishing, protection of culturally and naturally important areas, safe shipping routes and diverse recreation possibilities.

\section{Latvia}

The marine area of Latvia is owned and managed by the ministries of Environment, Agriculture, Transport, and Economics. Recently the task of planning and management of the zone $2 \mathrm{~km}$ seawards from the coastline has been given to local municipalities.

The Marine Environment Protection and Management Law (2010) of Latvia defines MSP as a long-term management process which aims at balancing the social welfare and economic development with the environmental protection requirements. The Law requires the management bodies to apply ecosystem approach and to take into account the environmental status and trends of the marine ecosystem. MSP should also take into account the activities in the terrestrial area that is functionally interlinked with the sea and reconcile the interests of various sectors and stakeholders in use of the sea.

The legal base for MSP is laid in the Spatial Development Planning Law (2011). The timing, content, as well as implementation and monitoring of MSP were approved by the Latvian Government in 2012. MSP should be harmonized with similar processes in the neighbouring states with which Latvia has a common sea border.

Other laws that need to be considered in the MSP process include, e.g., Maritime Administration and Marine Safety Law, Fishery Law, Law on Specially Protected Nature Territories and Law on Environmental Impact Assessment.

Development of a maritime spatial plan for the whole Latvian sea area was started in 2014 when a national MSP coordination group was established. The 1st draft was prepared during 2014 and 2015 with support from the BaltSeaPlan project (http://www.baltseaplan.eu/index.php/Latvian;839/1). National public consultations and cross-border consultation within the framework of ESPOO Convention were held in late 2015 and early 2016. The plan is to be approved by the Latvian Government in late 2016 or 2017 .

\section{Lithuania}

Current governance of the sea space is defined by (more than 20) legal acts relating to the use of the sea space, by international conventions and legal acts (such as CBD, UNCLOS, HELCOM) in which Lithuania participates.

MSP in Lithuania is included in the national legislation regulating spatial planning the revised Law on Territorial Planning (2014) and its secondary legal acts. Part of the 
marine space (up to $20 \mathrm{~m}$ isobath) also falls under the regulation of the Law of the Coastal Strip.

The Comprehensive Plan of the Territory of the Republic of Lithuania, which previously mainly considered the land areas, was in 2015 complemented by spatial solutions for the Lithuanian territorial waters and the EEZ. The Comprehensive Plan, and its part "Maritime territories", is a legally binding document.

The new Comprehensive Plan, that also includes the sea areas, aims at developing maritime economic activities, sustaining a good status of the marine environment, and safeguarding cultural heritage of the sea. Hence it, at least indirectly, also supports the provision of marine ecosystem services of Lithuania.

Russia

Russia does not have formal or legal procedures for MSP. The Federal Target Program "World Ocean", supported by the Ministry of Economic development, however provides justification and background for developing MSP in the Russian sea areas. Consequently, Russia has started adopting maritime spatial planning terminologies and practices via certain research and development projects in the Barents Sea and the Baltic Sea.

The Work plan of the Ministry of Natural Resources until 2018 includes a "Pilot project of integrated environmental management of the Arctic seas", which concerns the Russian part of the Barents Sea. In addition, a project supported by SIDA (the Swedish International Development Cooperation Agency) and World Wildlife Fund will (in 2016-2018) develop integrated coastal management of the Pechora Sea area, and include elements of MSP and discussions with stakeholders.

As for the Baltic Sea, there are two pilot MSP-related projects: (1) "Russian Application of the ecosystem approach to spatial planning in the pilot water area of the Russian Federation in the Baltic Sea" (a Russian-German project, with funding by Germany), and (2) the Finnish-Estonian-Russian "Gulf of Finland year 2014", during which the state of the Gulf of Finland was assessed, and data was collated to support building a spatial plan for the Gulf of Finland. 



\section{Appendix 8. Environmental pressures induce by individual marine/maritime sectors}

The environmental pressures induce by individual marine/maritime sectors are discussed below. A summary of the links between the activities and associated environmental pressures (following the typology put forward in the proposed revision of annex III, ${ }^{9}$ table 2 , of the marine strategy framework directive, 2008/56/EC) are found in table 7section 3.2. The information below is gathered from SWAM 2012, Garpe 2008, HELCOM 2010a and 2010b.

\section{Energy}

\section{Windpower}

Sea based wind farms impact the marine environment in several ways, both in the construction phase as well as in the operational phase. The major pressures associated with the construction phase are smothering which results from the actual construction on the seafloor and from siltation of spilled dredged material. Noise is also considered to be a significant pressure on the marine environment during the construction phase. During the operational phase, the major pressure is identified as barrier effect and the alteration of the natural environment. When the wind farms are decommissioned, the same pressures as in the construction phase reoccur.

\section{Nuclear power}

The primary environmental pressure induced by nuclear power plants is associated with the discharge of cooling water changing the local hydrographical conditions in in the vicinity of the discharge point due to its over temperature. The discharges of radioactive substances from power plants and research reactors is another source of pressure on the marine organisms in the Baltic Sea.

\footnotetext{
9 The proposed revision of annex III to the MSFD was accepted by the Marine Strategy Regulatory Committee on 10th November 2016. During the writing of this report, the proposed revision is being subjected to the scrutiny of the European parliament and council; https://circabc.europa.eu/sd/a/ff8555fc-1d49-42c5-b19b -

ogb91cdbb955/DRAFT\%20Commission\%20Directive\%2oreplacing\%20Annex\%2olll\%20MSFD.pdf
} 


\section{Wave power}

Wavepower plants have not yet been operationalized to such an extent for the environmental pressures to fully revealed themselves. It is however suspected that a large scale distribution might give rise to sound pollution, habitat alterations (particularly during the construction phase) as well as other disturbances. At the same time it may bring about a number of advantages when the additional hard surfaces provided by the installations attract certain species and at the same time offer local protection from fishing.

\section{Mining (extraction non-living resources)}

\section{Sand and gravel}

Physical damage to the seabed constitutes one of the major pressures on the Baltic Sea environment. Mining, exploitation of mineral resources, causes abrasion to the seabed and disturbance of the sediment structure by extraction of material.

Mining also implies changes in local siltation conditions when dredged material is spilled causing increased levels of turbidity affecting the marine organisms.

\section{Oil and gas}

Extraction of oil and gas implies a number of environmnetal pressures. The construction phase of oil riggs inflicts the same pressures as described during construction of seabased wind farms, i.e smothering resulting from the actual construction on the seafloor and increased siltation due to spilled dredged material. Noise and light are also considered to be significant pressures on the marine environment, both during construction and later in the operational phase of an oil rig. Extraction of oil and gas also lead to introduction of synthetic- as well as non-synthetic compounds due to oil spills. There are in addition spills of radioactive substances from oilrigs.

\section{Fisheries}

\section{Bentic trawling}

Bentic trawling is the fishing method that causes the most pressure on the marine environment. In addition to the extraction of target, as well as non-target species, the trawling equipment partly penetrates the seabed surface destroying all tredimensional structures and causing resuspension of sediment. Trawling also implies introduction of light as well as noise in the water column putting further pressure on the environment. Fishing in general is also a major source of marine litter. 


\section{Pelagic trawling}

Pelagic trawling is less harmful to the environment compared to bentic trawling. It does however inflict pressure in terms of extraction of target, as well as non-target species, marine litter, and introduction of light and noise in the water column.

\section{Potting/creeling and Set-netting}

The fishing methods potting, creeling and net-setting inflict pressure in terms of extraction of target, as well as non-target species, marine litter, and introduction of light and noise in the water column.

\section{Hunting}

There are three species of marine mamals in the Baltic Sea; grey seal, harbour seal and ringed seal. There is also one permanent whale species, the harbour porpoise.

\section{Aquaculture}

The main pressures caused by aquaculture is connected to input of nutrient, input of oganic matter and microbial pathogenes. The activity may also impact on the natural environment by the introduction of light and marine litter. Fish that escapes from the cages may also have a negative effect when mixing with indengenous species.

\section{Transports}

Marine transports (shipping) is another major source of impact on the marine environment. Anchoring and propeller currents cause abrasion to the seabed and changes in siltation rates, systematic oil spill from propeller shaft sealings and other sources of leakage and spills result in contamination by synthetic as well as nonsynthetic compounds, organic enrichment and introduction or spread or translocation of non-indigenous species. Shipping also generate pressure on the marine environment through light, noise and marine litter. Emissions from ships (sulphur \& nitrogen) also contribute to eutrophication (nitrogen) and acidification (sulphur) in the marine environment.

\section{Navigational routes}

In addition to the pressures described under shipping, the navigational routes are often subjected to dredging in order to maintain the clearance depth causing abrasion and changed siltation rates. The dredged materail is often deposited at subsurface landfills giving rise to smothering. 


\section{Harbours}

The pressures associated with harbours are found among those listed above for transports and navigational routes.

\section{Pipelines, telcom cables}

Construction of underwater pipelines and cables on the seabed inflict noise pressure on the marine environment, in addition it cases abrasion and changes in siltatioin rates. It is also suspected that electromagnetic fileds caused by high voltage cables disturb the ancient migration routes for fish.

\section{Coastal defence (erosion and flooding)}

The building of coastal defence structures such as jetties, different types of erosion protection, bridges and embankments result in seiling and smothering.

\section{Marine tourism and recreation}

All the activities that are gathered under the term marine tourism and recreation, e.g. swiming, angling, kajaking and leisure boating, contributes to the environmental pressure of the Baltic Sea, primarily through marine litter and organic enrichment. There is also significant impact locally by underwater noise caused by leisure boating and water sports.

\section{Coastal industries}

Discharge from coastal industries may include hazardous substances, nutrients, organic matter and litter. In addition, activities such as bunkering may result in oil spills. In case of discharge of heated cooling water, there might also be local hydrlological changes in terms of temperature.

\section{Military defence}

The pressure from military activiites may be attributed to underwater noise in relation to practice areas. When it comes to the ships themselves, the pressures are the same as those discussed under Transports. There area also numerous sites in the Baltic Sea where conventinal as well as chemical munitioin has been dumped, potentially resulting in the release of hazardous substances. 


\section{Appendix 9. Approach to assess impact on ecosystem services from environmental pressures}

\section{Three criteria for assessing environmental impact}

Following conservationsmeasures.org, we suggest three criteria which are assessed in a stepwise procedure. We further suggest that the scores of each of the three criteria are aggregated to one overall impact score, by filling in Table 4 below. The three criterias are:

- "How large is the impacted area?"

- "How severe is the impact in the area affected?"

- "Are the damages resulting from the impact reversible once they have occurred?"

We suggest the following levels for each of these criteria, building on the scores developed by conservationmeasures.org:

\section{Table 1: How large is the impacted area?}

Level of Definition

\section{impact}

Level 4:

impacted area is extensive. The ecosystem services are impacted nearly everywhere (i.e. 71-100\%)

Very high

where the ecosystem services occur within the relevant marine area (for example Northern Bohuslän).

Level 3: The impacts are widespread. The ecosystem services are impacted in a large part (i.e. 31-70\%) of the area

High where this ecosystem service is occurring within the relevant marine area. 
Table 2: How severe is the impact in the area affected?

\begin{tabular}{|c|c|}
\hline $\begin{array}{l}\text { Level of } \\
\text { impact }\end{array}$ & Definition \\
\hline $\begin{array}{l}\text { Level 4: } \\
\text { Very high }\end{array}$ & $\begin{array}{l}\text { The ecosystem service flow will probably be totally destroyed or greatly reduced; i.e. a reduction of } \\
71-100 \% \text { in the relevant area within a certain time ( } 10 \text { years). }\end{array}$ \\
\hline $\begin{array}{l}\text { Level 3: } \\
\text { High }\end{array}$ & $\begin{array}{l}\text { The ecosystem service flow will probably be severely damaged; i.e. a reduction of } 31-70 \% \text { in the relevant } \\
\text { area within a certain time (10 years). }\end{array}$ \\
\hline $\begin{array}{l}\text { Level 2: } \\
\text { Medium }\end{array}$ & $\begin{array}{l}\text { The ecosystem service flow will probably be reduced to some degree; i.e. a reduction of } 11-30 \% \text { in the } \\
\text { relevant area within a certain time (10 years). }\end{array}$ \\
\hline $\begin{array}{l}\text { Level 1: } \\
\text { Low }\end{array}$ & $\begin{array}{l}\text { The ecosystem service flow will probably be reduced to a very limited degree; i.e. a reduction of } 1-10 \% \\
\text { in the relevant area within a certain time (10 years). }\end{array}$ \\
\hline
\end{tabular}

Table 3: Is the level of irreversibility of damages to ecosystem services resulting from the impact once they have occurred?

\begin{tabular}{|c|c|}
\hline $\begin{array}{l}\text { Level of } \\
\text { impact }\end{array}$ & Definition \\
\hline $\begin{array}{l}\text { Level 4: } \\
\text { Very high }\end{array}$ & $\begin{array}{l}\text { The damages cannot be repaired, or it is very difficult to restore the ecosystem services. It will probably } \\
\text { not be possible to restore them or it would take more than } 100 \text { years }\end{array}$ \\
\hline $\begin{array}{l}\text { Level 3: } \\
\text { High }\end{array}$ & $\begin{array}{l}\text { Technically the damages may be repaired, and the ecosystem services restored, but it is probably not } \\
\text { economically feasible and/or it would take } 21-100 \text { years. }\end{array}$ \\
\hline $\begin{array}{l}\text { Level 2: } \\
\text { Medium }\end{array}$ & $\begin{array}{l}\text { The damages may be repaired and the ecosystem services restored with the use of a reasonable } \\
\text { amount of resources, and/or within 6-20 years. }\end{array}$ \\
\hline $\begin{array}{l}\text { Level 1: } \\
\text { Low }\end{array}$ & $\begin{array}{l}\text { The damages may be repaired easily, and the ecosystem services restored for a small amount of } \\
\text { resources and/or within } 5 \text { years or less. }\end{array}$ \\
\hline
\end{tabular}

\section{Overall impact score on ecosystem services}

The scores for each criterion range from low (1) to medium (2), high (3), and very high (4). The possible scores are provided in the table below. If we want, or need, to combine the scores for each criterion to calculate an overall impact score, this may be done as shown in the small table below (Table 4). Here, we have assumed that each criterion is given equal weight when we combine the scores. This is not necessarily the case. If one for instance, believes irreversibility is more important than the other impact criteria, this could be given a higher weight when calculating the overall score. However, as a default, we suggest each criterion has equal weight, as we have shown Table 4 below. 
Table 4: Criteria for deciding the size of the overall impact on an ecosystem service from a maritime activity

\begin{tabular}{|c|c|c|c|c|c|}
\hline Criteria & $\begin{array}{l}\text { Avai } \\
\text { see }\end{array}$ & $\begin{array}{l}\text { lesc } \\
\text { ve }\end{array}$ & levels, & $\begin{array}{l}\text { Assessment (scores, 1-4, } \\
\text { filled in by the user) }\end{array}$ & \\
\hline Size of impacted area & 1 & 2 & 3 & & 3-4 Low \\
\hline Severity of impact & 1 & 2 & 3 & & 5-7 Medium \\
\hline Irreversibility of damage & 1 & 2 & 3 & & 8-10 High \\
\hline \multicolumn{5}{|c|}{ Overall impact score ( $\sum$ criteria 1-3) } & 11-12 Very high \\
\hline
\end{tabular}





\section{Appendix 10. Assessing the level of dependency on ecosystem services}

To establish the criteria for assigning dependency scores, we suggest that the experiences from recent studies conducted for government agencies in Norway (Vista Analyse 2012/13: Miljøforringelse i Nordsjøen, Magnussen et al. (2012)) are used.

We suggest two criteria which are assessed one by one, the score for each criterion are aggregated to calculate an overall dependency score. The two criteria are "dependency of the quality of the ecosystem service" and "dependency of the quantity of the ecosystem service".

The uncertainty in the dependency assessments does not justify a more detailed scale than four levels in our opinion. We suggest two criteria which are assessed one by one, and then the score for each criterion is aggregated to one overall dependency score, as shown in the table below. The two criteria are "dependency of the quality of the ecosystem service" and "dependency of the quantity of the ecosystem service". We suggest the following levels for each of these criteria:

\section{Table 1: Dependency of the quantity of the ecosystem service}

\section{Level of impact Definition}

Level 1: Low $\quad$ Activity depends on the availability of the ecosystem service in a small part (i.e. 1-10\%) of the planning area where the ES is found

Level 2: Medium Activity depends on the availability of the ecosystem service in a medium part of the planning area where this ES is found (i.e. $10-30 \%$ of planning area).

Level 3: High Activity depends on the availability of the ecosystem service in a large part of the planning area where this ES is found (i.e. $30-70 \%$ of planning area).

Level 4: Very high Activity depends on the availability of the ecosystem service in a very large part of the planning area where this ES is found (i.e. $71-100 \%$ of planning area).

Table 2: Dependency of the quality of the ecosystem service in the area where it is found

\section{Level of impact Definition}

Level 1: Low Level 2: Medium

Level 3: High

Level 4: Very high
Activity can be carried out even with a low quality of the ecosystem service in the area it is found. Activity is dependent on a reasonable (medium) quality of the ecosystem service in the area it is found. Activity is dependent on a high quality of the ecosystem service in the area it is found. Activity is dependent on a very high quality of the ecosystem service in the area it is found. 
Table 3: Criteria for deciding an activity's overall dependency of an ecosystem service

\begin{tabular}{l|l|l|l|l|}
\hline Criteria & $\begin{array}{l}\text { Available score levels, } \\
\text { see above }\end{array}$ \\
\hline $\begin{array}{l}\text { 1. Quantity of the } \\
\text { ecosystem service }\end{array}$ & 1 & 2 & 3 & 4 \\
\hline $\begin{array}{l}\text { 2. Quality of the ecosystem } \\
\text { service }\end{array}$ & 1 & 2 & 3 & 4 \\
\hline
\end{tabular}

Overal

filled in by the user) $\quad$ dependency

score

2 Low

3-5 Medium

6-7 High

Overall dependency score ( $($ criteria 1-3)

$>7$ Very high 


\section{Appendix 11. Marine ecosystem services valuation methods}

\section{Primary Valuation techniques}

Some marine and coastal ecosystem services (ES) are traded in markets, and can be valued in monetary terms based on market prices (e.g. provisional services like commercial fisheries). Other ES, especially regulating and cultural ES, typically have no market prices, and can be valued by non-market valuation methods only. These methods include revealed preference (RP) and stated preference (SP) methods. RP methods use observational data from decisions people make in markets to estimate the value of changes in an ES flow, and include among others the travel cost method (TC) method to estimate recreational benefits. SP methods use data generated from surveys eliciting people's contingent preferences in constructed (hypothetical) market scenarios, and include the Contingent Valuation (CV) method, Choice Experiments (CE), and variants of these. The aim of SP methods is to estimate the affected population's willingness-to-pay (WTP), directly or indirectly, to obtain a positive stream of ES or avoid further reduction. While the valuation methods have been tried and tested for many years, applications using the ES framework fully are relatively recent (TEEB (2010b), Nunes et al. 2014, Navrud et al. 2016). Scientific uncertainty, spatial explicitness and temporal stability of values, definition of affected populations and aggregation over both ES use and non-use values, are important questions also for marine and coastal planning (Luisetti et al. 2011; Raheem et al. 2012; Sanchirico et al. 2013; Marre et al. 2015).

Figure 1 illustrates the temporal flow of marine and coastal ES, and ES loss/damage due to an external stressor, illustrated in this case by a marine oil spill. The economic value of ES impacts is the area of interim welfare loss (damage costs) caused by the oil spill. 
Figure 1: Temporal flow of marine and coastal ecosystem services (ES), and the service loss/damages due to an oil spill; with and without active restoration of the services

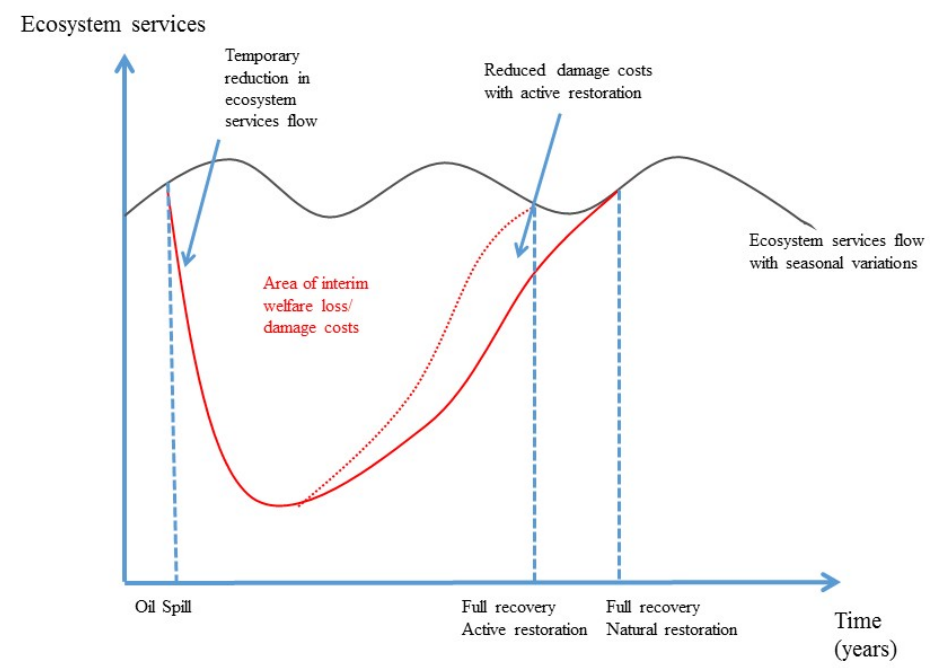

The economic valuation of environmental, cultural heritage and health impacts would typically be based upon individual preferences, either observed behaviour (revealed preferences; RP) towards some marketed good with a connection to the non-market good of interest; or stated preferences (SP) in surveys with respect to the non-marketed good. Table 1 provides an overview of the different types of RP and SP valuation technique, which can be used to estimate some or all parts of the Total Economic Value (TEV), i.e. both use and non-use values, of a change in ecosystem services affected impacted by different stressors.

Table 1: Classification of (Primary) Environmental Valuation Methods

Revealed Preferences (RP)

Household Production Function (HPF) approach

- Travel Cost (TC) method

- Averting Costs (AC)

Hedonic Price (HP) analysis

Stated Preferences (SP)
Market prices /

Productivity Approach

Replacement Costs (RC)

Contingent Valuation (CV)

\section{Revealed Preference (RP) methods}

Revealed Preference techniques can be divided into direct and indirect methods. Among the direct methods are the use of dose-response functions (or expert assessments/Environmental Impact Assessments) of impact, valued by market prices. This can be applied to e.g. impacts on commercial fisheries and aquaculture. This approach uses only the physical or biological dose-response relationship to estimate the response to a change in some environmental parameter. The observed market price 
of the activity or entity is then multiplied by the magnitude of the physical or biological response to obtain a monetary measure of damage. Thus, neither behavioural adaptations nor price responses are taken into account. Simple multiplication provides an accurate estimate of economic behaviour and value - in this case changes in gross revenue - only if economic agents are limited in the ways in which they can adapt to the environmental effect, and if the effect is small enough to have little or no impact on relative prices. This combination of circumstances is very unlikely. If e.g. damages to commercial fisheries are large enough to change prices, changes in consumer and producer surpluses have to be calculated. If fishermen undertake preventive measures, like switching to species that are less sensitive to the external stressors, the simple multiplicative approach will overestimate damage costs.

Another direct RP method is the Replacement Cost method (RC); also termed the restoration cost method. This approach has been used to calculate loss of ecosystem services like the waste water treatment service of coastal wetlands, in terms of the costs of building a waste water treatment plant with the same capacity as the wetland. This approach assumes that the replacement project provides a perfect substitute for the lost ES. This is often not the case, e.g. artificial coral reefs made of PVC do not "cover" ES like the aesthetic beauty of a coral reef. Thus, one should bear in mind that these replacement or restoration costs might bear little relationship to true social values. Thus, individuals' willingness-to-pay (WTP) for replacing/restoring ES could be either more or less than the cost of replacement.

The greatest advantage of these direct RP methods is that they are relatively simple to use. However, the methods ignore the behavioural responses of individuals to changes in the ES. They also obscure the distinction between benefits and costs, as there is no guarantee that people are actually willing to pay the estimated cost.

The indirect RP methods entail two main groups of methods; the household production function approach (including the popular Travel Cost and Averting Cost methods) and the Hedonic Price analysis.

The Household Production Function (HPF) approach involves investigating changes in consumption of commodities that are substitutes or complements to the ES. The Travel Cost (TC) method, used widely to measure the demand for recreation, is a prominent example. The costs of travelling to a recreational site like a beach (together with participation rates, visitor attributes, and information about substitute sites) are used to derive a measure for the use value of the recreational activity at the site. TC models builds on a set of strict assumptions, which are seldom fulfilled, and the results are sensitive to the specification of the TC model, the choice of functional forms, treatment of travel time and substitute sites etc. However, they can be relatively cheap to perform (compared to SP methods), and give reasonably reliable estimates for use values of natural resources; e.g. recreational use values of beaches for the current quality of a site. To calculate changes in recreational value, the TC method must be combined with contingent behaviour questions, in order to assess the change in the recreational activity due to the ES impact from external stressors.

Another example of the use of the HPF approach is the use of Averting Costs (AC); also known as defensive or preventive expenditures to infer value. Averting inputs 
includes buying bottled water and water purification systems to mitigate personal impacts from e.g. bad drinking water. Such inputs would then substitute for this change in ES. This approach assumes that consumers buy theses averting output up to this input is a perfect substitute for.

HPF uses actual behaviour as the basis for valuation, but is limited to use value. Non-use values, that do not entail direct consumption, cannot be estimated by looking at complements or substitutes. HPF approaches have mostly been used to value recreational activities, noise and visual amenities.

Hedonic Price (HP) analysis refers to the estimation of implicit prices for individual attributes of a market commodity. Some ES can be viewed as attributes of a market commodity such as residential houses. For example; proximity to windmills and electric transmission lines, sewage treatment plants and waste disposal sites, fish farms, and access to scenic vistas of the ocean; are purchased along with residential property. Part of the variation in property prices is due to differences in these amenities. HP data can be quite costly to get, as there is often no database of residential properties, that have data on environmental amenities and other attributes which determine the property price. The HP function is very sensitive to the specification and functional form, and it is often difficult to find a measure for the environmental amenity where data exist, and which the bidders for residential properties can recognize marginal changes in and has complete information about at the time they bid for the property.

\section{Stated Preference (SP) methods}

While (indirect) RP methods are based on actual behaviour in a market for goods related to the environmental good in question (and thus the value for the environmental goods is elicited based on sets of strict assumptions about this relationship), Stated Preference (SP) methods measure the value of the environmental good in question by constructing a hypothetical market for the good. The hypothetical nature is the main argument against SP methods. However, no strict assumptions about the relationship between the marketed good and the ES have to be made. SP methods also have the advantage of being able to measure the Total Economic Value (TEV), i.e. both use and non-use values, and can also measure future changes in environmental quality and ES.

The SP methods can be divided into direct and indirect approaches. The direct Contingent Valuation (CV) method is by far the most used method, but over the past few years the indirect approach of Choice Experiments (CE) has gained popularity. The main difference between these two approaches is that while the CV method typically is a two-alternative (referendum) approach or a payment card, CE employs a series of questions/choices between two alternatives (and often a status quo alternative) described by different characteristics/attributes including the cost of providing the alternative. CE is designed to elicit preferences and values for attributes of ES.

A Contingent Valuation (CV) survey constructs scenarios that offer different possible future government actions. Under the simplest and most commonly used CV question format, the respondent is offered a binary choice between two alternatives, one being 
the status quo policy, the other alternative policy having a cost greater than maintaining the status quo. The respondent is told that the government will impose the stated cost (e.g. increased taxes, higher prices associated with regulation, or user fees) if the non-status quo alternative is provided. The key elements here are that the respondent provides a "favour/not favour answer" with respect to the alternative policy (versus the status quo), what the alternative policy will provide, how it will be provided, and how much it will cost, and how it will be charged for (i.e. payment vehicle), have been clearly specified. This way of eliciting WTP is termed binary discrete choice (DC). In such a closed-ended version of $\mathrm{CV}$, respondents can also be asked to value multiple discrete choices in double- and multiple DC WTP questions. An alternative elicitation method is open-ended questions where respondents are asked directly about the most they would be willing to pay to get the alternative policy. A payment card with amounts ranging from zero to some expected upper amount is often used as a visual aid to ease the cognitive burden on the respondents. Then the data could be treated statistically as interval data; i.e. if you say "yes" to pay SEK 50 as the highest amount, but say "no" to SEK 100, we know that the respondent has a WTP within this range. One of the main challenges in a CV study is to describe the change in the ES the new policy/program will provide in a way that is understandable to the respondent and at the same time scientifically correct.

Producing a good CV survey instrument requires substantial development work; typically including focus groups, in-depth interviews, pre-test and pilot studies to help determine whether people find the good and scenario presented plausible and understandable. The task of translating technical material into a form understood by the general public is often a difficult one; see e.g. Navrud et al. (2015) for an application to marine ES in a Nordic context.

Choice experiments (CE) ask respondents to pick their most favoured out of a set of three or more alternatives, and are typically given multiple sets of choice questions. Because CEs are based on attributes, they allow the researcher to value attributes as well as situational changes in ES. Furthermore, in the case of damage to a particular attribute, compensating amounts of other goods (rather than compensation based on money) can be calculated. An attribute-based approach is necessary to measure the type or amount of other "goods" that are required for compensation This approach can provide substantially more information about a range of possible alternative policies as well as reduce the sample size needed compared to Contingent Valuation (CV). However, survey design issues with the CE approach are often much more complex due to the number of goods that must be described and the statistical methods that must be employed. Aanesen et al. (2015) provides a recent example of applying CE to marine and coastal ES in the Nordic countries.

Although results from primary valuation studies using all these valuation methods could be used for value transfer; $\mathrm{CV}, \mathrm{CE}, \mathrm{TC}$, and $\mathrm{HP}$ methods dominate value transfer. 


\section{Value transfer}

Value transfer (VT) involves transferring economic estimates from previous primary valuation studies (often termed study sites) of similar changes in ecosystem services to value the change in the quality or quantity of theses public goods at the policy site. This procedure was initially termed benefit transfer (Desvousges et al., 1998), and although the term has stuck in the literature, a more general term increasingly used is value transfer as damage estimates can also be transferred (see e.g. Navrud and Ready, 2007).

There are four requirements for valid VT:

- Databases of primary valuation studies (to transfer values from).

- Guidelines for assessing quality of primary valuation studies.

- Value transfer techniques.

- Value transfer guidelines.

\section{Database for primary valuation studies}

The first requirement concerns a database for primary valuation studies with enough detail to judge similarity between the impacts valued in primary studies and the policies one is using value transfer to evaluate. Instead of having to conduct detailed literature searches and reviews every time the environmental and health impacts of new chemicals need to be assessed, a database of valuation studies of relevant environmental and health impacts would greatly ease this task. While such detailed databases have been constructed for meta-analyses of valuation studies of specific environmental and health impacts, they are usually not updated nor easily available. The Environmental Valuation Reference Inventory (EVRI), www.evri.ca, remains the most comprehensive and updated international database for both primary studies and meta-analyses valuing both environmental and environmentally related health impacts. However, the EVRI entries of primary studies often contain less detailed data than the databases of studies constructed for meta-analysis; and the information collected about each primary valuation study in EVRI will in some cases not be sufficient for the value transfer techniques and guidelines. Thus, the reporting of the valuation estimates and data for variables known to affect the value estimates should be specified in detail by the authors (e.g. as electronic appendices to journal articles and reports), and in a way, that allows both a detailed quality assessment of the study and improved value transfer.

\section{Guidelines for assessing quality of primary valuation studies}

Regarding the second requirement listed above, guidelines for assessing the quality of Stated Preference (SP) and Revealed Preference (RP) methods valuing environmental impacts can be found in e.g. Söderqvist and Soutukorva (2006), while publications like 
the recent US EPA (2016) provide guidance for judging the quality of SP and RP studies valuing mortality risk.

Value transfer techniques are the third requirement. The three main techniques for spatial and temporal value transfer: i) unit value, ii) function transfer and iii) meta-analysis.

\section{Value transfer techniques}

There are two main types of unit transfer: i) Simple (naïve) unit value transfer, and ii) Unit value transfer with income adjustments.

Simple (naïve) unit value transfer (in terms of a mean value from one study, or as a mean value estimate from several studies) is the simplest approach to transferring value estimates from a study site (or as a mean from several study sites) to the policy site. This approach assumes that the wellbeing experienced by an average individual at the study site is the same as will be experienced by the average individual at the policy site, and that the environmental or health impact in question is valued the same at the two sites. One directly transfers the mean value estimate, ${ }^{10}$ usually expressed as mean willingness-to-pay (WTP) per household per year (or as a one-time amount) to avoid or get a specified change in the quantity or quality of an environmental good (or as individual consumer surplus per activity day for recreational use values), from the study site to the policy site. For many decades, simple unit value transfer, in terms of the mean value of previous national valuation studies, was routinely used by the United States Department of Agriculture (USDA) Forest Service to establish a set of recreational use values per activity day for recreational activities to be used in CBAs of forest management practices in the USA. However, the last decade or so these unit values have been based on meta-analyses (Loomis, 2015). In the United States, simple unit value transfer has also been used in Natural Resource Damage Assessments (NRDA), called Type A assessments, of toxins and heavy metals from hazardous waste sites and mines but also for impacts on marine and coastal resources from oil spills (Loomis, 2015). The obvious problem with simple unit value transfer for recreational activities is that individuals at the policy site may not value recreational activities the same as the average individual at the study sites. There are two principal reasons for this difference. First, people at the policy site might be different from individuals at the study sites in terms of income, education, religion, ethnic group or other socioeconomic characteristics that affect their demand for recreation. Second, even if individuals' preferences for recreation at the policy and study sites were the same, the recreational opportunities (i.e., substitute sites and activities) and the change in the good valued might not be. Unit values for non-use values of e.g. ecosystem services from Contingent Valuation (CV) studies might be even more difficult to transfer than

\footnotetext{
${ }^{10}$ However, as the unit value often originates from a study conducted some years ago, it is often adjusted for inflation to account for changes in value over time and implicitly assuming that people's valuation of environmental and health effects increase with the same rate as the domestic Consumers Price Index. This is a strict assumption as changes in peoples valuation of health and environmental impacts might be very different from changes in the CPI (see e.g. Zandersen et al., $2007 \mathrm{a}, \mathrm{b})$, and also the change in their real income over time could influence their valuation. The latter effect is typically corrected for in the adjusted unit value transfer approach discussed below.
} 
recreational (use) values for at least two reasons. First, the unit of transfer is more difficult to define. While the obvious choice of unit for use values is recreational value per activity day, there is greater variability in reporting non-use values from CV surveys, both in terms of WTP for whom, and for what time period. WTP might be reported both per household or per individual, and as a one-time payment, an annual payment for a limited time period, an annual payment for an indefinite time, or even as monthly payments. Second, the WTP is reported for one or more specified discrete changes in ecosystem services, and not on a marginal (e.g. per ha) basis.

For ecosystem services, WTP per household per year would be the preferred transfer unit, and then the unit value would be aggregated over the total number of affected households (i.e. households whose utility is affected by the impact) in order to get an estimate of total benefits (or costs). Using WTP per individual per year for environmental goods might lead to overestimation of total benefits when aggregated over individuals, as shown by e.g. Lindhjem and Navrud (2009). WTP as a one-time amount might lead to underestimation of annual WTP, as reported WTP will be the present value of a flow of annual WTP amounts and will be constrained by their income in the year they report their one-time amount WTP. Using this transfer unit for a specified change in ecosystem services also avoids the procedure of scaling up and down reported WTP to the size of the area at the policy site. Such scaling assumes a constant value per ha. (and no nonlinerarities in valuation); which does not seem to be the case in practice (See e.g. Lindhjem, 2007; Lindhjem and Navrud, 2008 and Kaul et al., 2013).

Thus, simple value transfer for ecosystem services impacts could be based on estimates from only one primary study or the mean estimate from many valuation studies considered being close to the policy site; both geographically and culturally, and in terms of similarity of the characteristics of the pubic good valued.

The simple unit value transfer approach should not be used for transfer between countries with different income levels and costs of living (or between regions with very different income levels within a country). Then, unit transfer with income adjustments should be applied if one is conducting unit value transfer. The adjusted WTP estimate $\mathrm{Bp}^{\prime}$ at the policy site can be calculated as:

WTPp' $=$ WTPs $(Y p / Y s) ß$

where WTPs is the original WTP estimate from the study site, Ys and Yp are the income levels at the study and policy site, respectively, and $B$ is the income elasticity of WTP for the environmental good in question. This income elasticity of WTP (ß) for different ES impacts is typically smaller than 1 , and often in the $0.3-0.7$ range (Kriström and Riera, 1996; Hökby and Söderqvist, 2003). When one lacks data on the income levels of the affected populations at the policy and study sites, Gross Domestic Product (GDP) per capita has been used as a proxy for income in international benefit transfers. However, this approach could give wrong results in international benefit transfers when income levels at the local study and/or policy site deviates from the average income level at the national level. 
Using the official exchange rates to convert transferred estimates in e.g. U.S. dollars to the national currencies in the Nordic countries does not reflect the true purchasing power of currencies, since the official exchange rates reflect political and macroeconomic risk factors. If a currency is weak on the international market (partly because it is not fully convertible), people tend to buy domestically produced goods and services that are readily available locally. This enhances the purchasing powers of such currencies on local markets. To reflect the true underlying purchasing power of international currencies, the International Comparison Program (ICP) has developed measures of real GDP on an internationally comparable scale. The transformation factors are called Purchasing Power Parities (PPPs). ${ }^{11}$

Even if PPP-adjusted GDP figures and exchange rates can be used to adjust for differences in income and cost-of-living in different countries, doing so will not correct for differences in individual preferences, baseline levels of environmental quality, ecosystem services and public health nor international differences in cultural and institutional conditions (or even within different parts of a country). Thus, population characteristics should be as similar as possible between the study and policy sites.

Value function transfer is conceptually and theoretically more appealing than just transferring unit values because information about how all characteristics of the households (not only income) and the characteristics of ecosystem service in question could in principle be transferred as a function of WTP. The evidence is mixed with regards to whether function transfers perform better than unit value transfer for environmental and health impacts. For example, Ready et al. (2004) found unit value transfer to perform better than function transfer for environmentally related public health impacts while Bateman et al. (2011) found the opposite result for water quality improvements. In many instances, value function transfer does not seem to reduce transfer errors significantly compared to simple (naïve) unit value transfer. Bateman et al. (2011) also note that their result that value function transfer outperforms unit value transfer in their international value transfer validity test of WTP for water quality improvements in five European countries is based on transfer of highly similar sites and commodities.

The value relationship to be transferred from the study site(s) to the policy site could be estimated using either revealed preference (RP) approaches like the Travel Cost (TC) and Hedonic Price (HP) methods or stated preferences (SP) approaches like the Contingent Valuation (CV) method and Choice experiments (CE). For a CV study, the value function can be written as:

$$
\text { WTPij }=b_{0}+b_{1} G j+b_{2} H i j+e
$$

where WTPij = the willingness-to-pay of household (or individual if one is valuing health impacts) $i$ at site $j, G j=$ the set of characteristics of the environmental good or health impact at site $j$, and $\mathrm{Hij}=$ the set of characteristics of household/individual $i$ at site $j$, and bo, b1 and b2 are sets of parameters, and e is the random error.

${ }^{11}$ For ICP, see http://siteresources.worldbank.org/ICPEXT/Resources/ICP_2011.html 
To implement this approach, the analyst would have to find a study in the existing literature with estimates of the constant bo and the sets of parameters, b1 and b2. Then the analyst would have to collect data on the two groups of independent variables, $G$ and $\mathrm{H}$, at the policy site, insert them in equation (2), and calculate households' WTP at the policy site. One challenge in value function transfer is the lack of data at the policy site for the independent variables explaining most of the variation in WTP at the study site. Thus, instead of using the "best" value function (in terms of significant variables and highest explanatory power), one has to resort to the second-best option in terms of a value function containing variables for which there are data at the policy site.

Another problem with the value function approach is due to the exclusion of relevant variables in the WTP (or bid) function estimated in a single study. When the value function is based on observations from a single study of a recreational site, a specific change in environmental quality or a specific illness episode, a lack of variation in some of the potentially important independent variables usually prohibits inclusion of these variables. For domestic value transfers, researchers tackle this problem by choosing the study site to be as similar as possible to the policy site with regards to socioeconomic and health characteristics of the population and/or the environmental quality or ecosystem service change in question.

Instead of transferring the value function from one selected valuation study, results from several valuation studies could be combined in a meta-analysis to estimate one common value function for all these primary valuation studies. Meta-analysis has been used to synthesize research findings and improve the quality of literature reviews of valuation studies in order to come up with adjusted unit values. In a meta-analysis, several primary valuation studies are analyzed as a group, where the estimates from each study is treated as a single observation in a regression analysis. If multiple estimates from each study are used, various meta-regression specifications can be used to account for such panel effects.

Meta-analysis allows one to evaluate the influence of a wider range in characteristics of the environmental good or health impacts, the features of the samples used in each analysis (including characteristics of the population affected by the change), and the modelling assumptions. In practice, however, detailed characteristics of the good or study site and the population are often not reported in the primary studies (in particular, if they are published journal papers, which often focus on methodological tests of valuation methods rather than reporting monetary estimates and the data needed in a meta regression analysis), and it requires a large effort to find them (if at all possible). The resulting regression equations explaining variations in unit values can then be used together with data collected on the independent variables in the model that describes the policy site in order to construct an adjusted unit value. The regression from a meta-analysis would look similar to equation (2), but a set of variables reflecting differences in the valuation methods applied need to be added; i.e. Cs = characteristics of the methodology applied in study $s_{i}$ as meta-analyses typically find that differences in valuation methods account for a significant part of the variation in mean WTP across studies s; WTPs. 


\section{Value transfer guidelines}

The fourth requirement for VT is Value transfer guidelines should be practical and simple to use, and show in a transparent and step-by-step manner how one can arrive at economic values for health and environmental impacts of chemicals. The guideline below are based on other similar general guides for value transfer for environmental goods, like the Danish EPA Guidelines (Navrud, 2007) and the UK Defra Guidelines (Bateman et al., 2009).

Eight main steps for value transfer for ecosystem services can be identified:

- Identify the environmental endpoints or impacts to be valued at the policy site.

- Identify the affected population at the policy site and their characteristics influencing their values of the respective impact.

- Conduct a literature review (from databases of primary studies and other sources) in order to identify relevant primary studies; preferably of a population with similar characteristics as the population at the policy site.

- Assess the relevance and quality of study site values for transfer.

- Select and summarize the data available from the study site(s).

- Transfer value estimate from study site(s) to policy site.

- Calculate total social benefits or costs; aggregated over the affected population and geographical area, and over time, in terms of their Present Value (PV).

- Assess the uncertainty and transfer errors.

Applying the Contingent Valuation method to value damages to marine ecosystem services from oil spills from ships to provide unit vale transfer estimates in a Cost-Benefit Analysis Manual

A Contingent Valuation survey carried out an internet panel survey of a representative sample of more than 2,000 Norwegian households. The aim of the survey was to develop damage cost estimates for different size marine and coastal ecosystem service losses due to oil spills from ships. The survey was financed by the Norwegian Coastal Administration (NCA) in order to provide economic estimates of the benefit side of the cost-benefit analyses they conduct of preventive measures to reduce the risk of oil spills. The map and the table below show the damage scenario as presented to the respondents in the survey. 

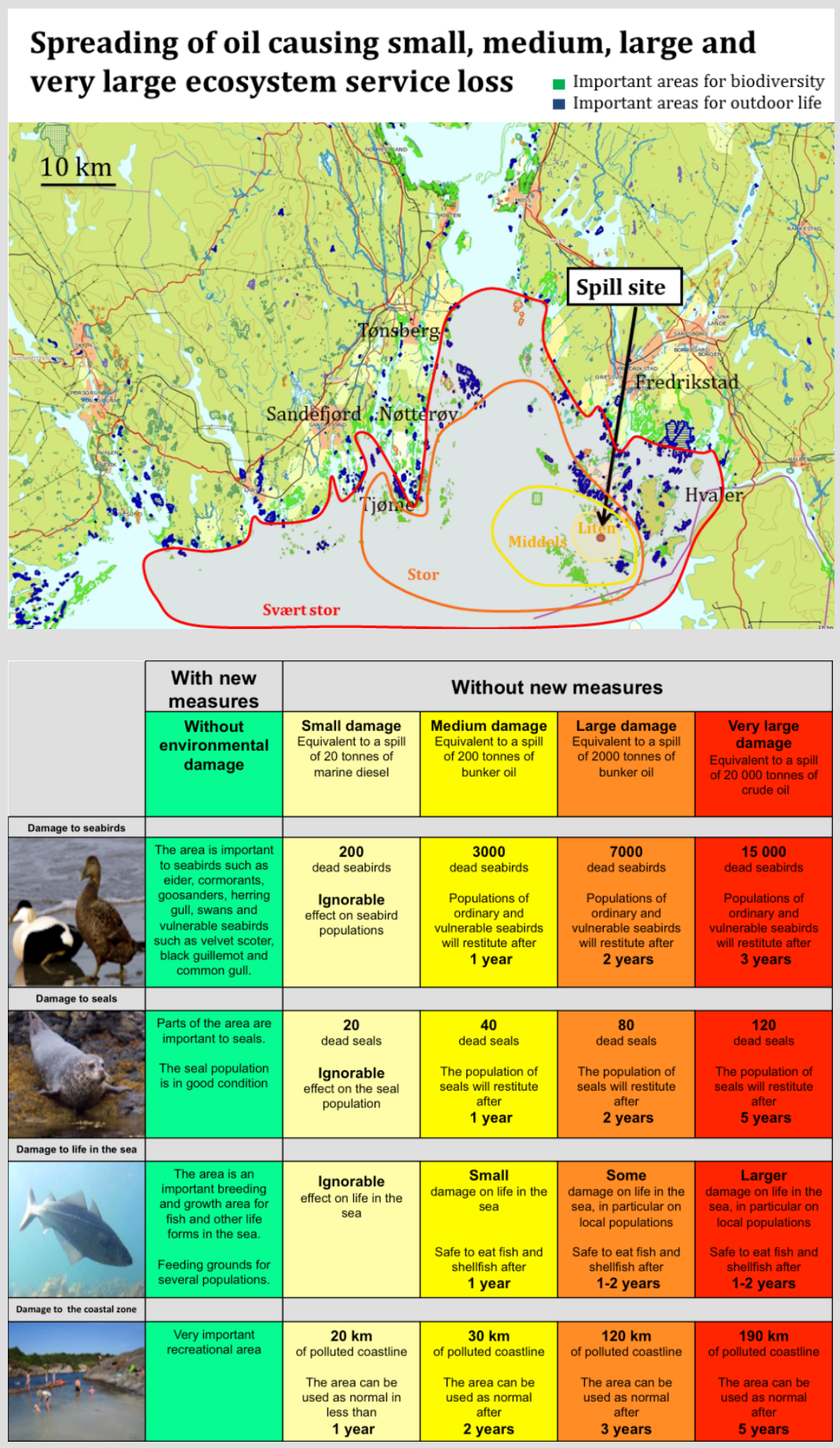

The respondents were told that without new preventive measures there would be an oil tanker accident in the next few years causing either small medium, large or very large ecosystem service in the outer Oslofjord, as shown in the table and map below. If preventive measures are put in place, these ecosystem service losses would be prevented. Businesses, the shipping industry, the government and households all make use of shipping, meaning that all parties must pay for measures that prevent environmental damage from oil spills. 
All households in the region have to cover their share of the costs. Then the households are asked to think about what is was worth to their household to avoid first the small loss, then medium, large and the very large loss, and instead getting the "With measures" situation. Note that this best, "status quo" situation is shown in green, whereas the other losses follow a "traffic light" design where the very large loss is in red. They are then asked to state the highest amount, if any, they certainly would pay in terms of increased annual income tax (which was seen as a fair and realistic payment vehicle) to avoid each of these four ecosystem service loss levels. They are shown a horizontal scale with random amounts from NOK o to 10,000 with options to state higher amounts than NOK 10,000 and "don't know", and asked to move the slider to their highest amount, for each of the four loss levels. The results are shown below for the Oslofjord spill depicted here and three other spill sites covering different parts of Norway's long coastline. Average willingness-to-pay (WTP) amounts are in NOK/household/year for 10 years. Results show, in accordance with economic theory, that people are willing to pay more for more, i.e. WTP increase as the ecosystem service losses avoided increase. Results also show that people in Northern Norway are willing to pay more that people from other regions in Norway. This could, at least partly, be due to their close connection and dependence to marine resources. This study was a large scale pilot survey forming the basis for an even larger internet panel survey of 5,000 households in Norway, providing unit value estimates for the four loss levels, to be used in value transfer in NCAs Cost-Benefit Analysis Manual.

\section{Figure 2: Level of ecosystem service loss}

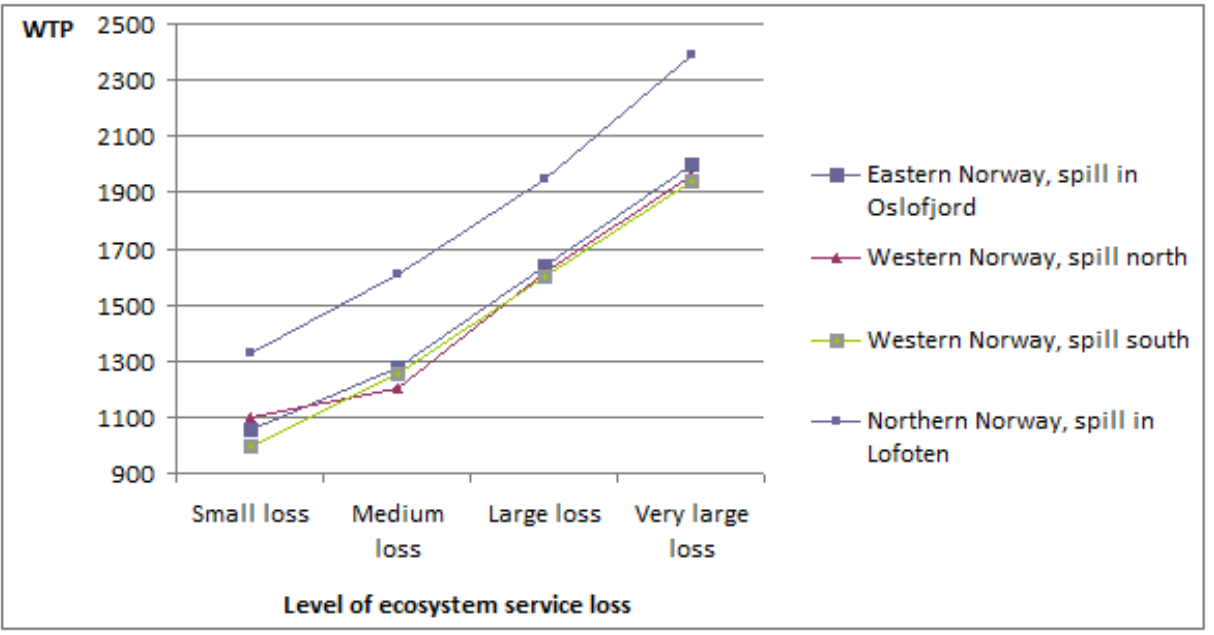

Source: Navrud, S., H. Lindhjem and K. Magnussen 2016: Valuing Marine Ecosystem Services Loss from Oi Spills for Use in Cost-Benefit Analysis of Preventive Measures. Forthcoming in Nunes, P. A.L.D., P. Kumar, L. E. Svensson, and A. Markandya (eds.) 2016: Handbook on the Economics and Management for Sustainable Oceans. Edward Elgar Publishing, Cheltenham, UK. 



\section{Appendix 12. Tradeoffs}

\section{Tradeoffs between goods and services}

Much of the literature on tradeoffs between ES, analyses ecosystem services measured in physical units, e.g. water quality and quantity, fish production, etc. (Kareiva et al. 2011). Obviously, there may be purely biological tradeoffs: More of one ecosystem services result in less of one or several others. For example, increased fishing of one species can reduce the fish catch of another species or of other services in the river. There are complicated and often not well-known ecological relationships between different provisioning, regulating and cultural services. How these relationships are in the watersheds will be important for how different uses affect the functioning of ecosystems. One central question in an economic analysis is what someone has to give up of one service in order for someone (else) to receive more of another. This tradeoff is dependent on the underlying physical and ecological relations, but also on how the different ecosystem services are valued on the margin. Figure 3.1 can illustrate this point (based on Polasky et al. 2011).

Suppose that there are four political choices, regulations or measures that are considered for a particular ocean area (points A, B, C and D in the figure) and that the costs of these measures are equal. Suppose further that there are two ecosystem services or potential uses only. These two services are marked as Ecosystem Service 1 and 2 respectively on the two axes in Figure A.12.1. Each of the four alternatives gives different combinations of the two ecosystem services. We can interpret the axes as showing physical units or economic units (EUR). 
Figure 1: Simplified example of combinations of level on two different ecosystem services under four hypothetic management regimes

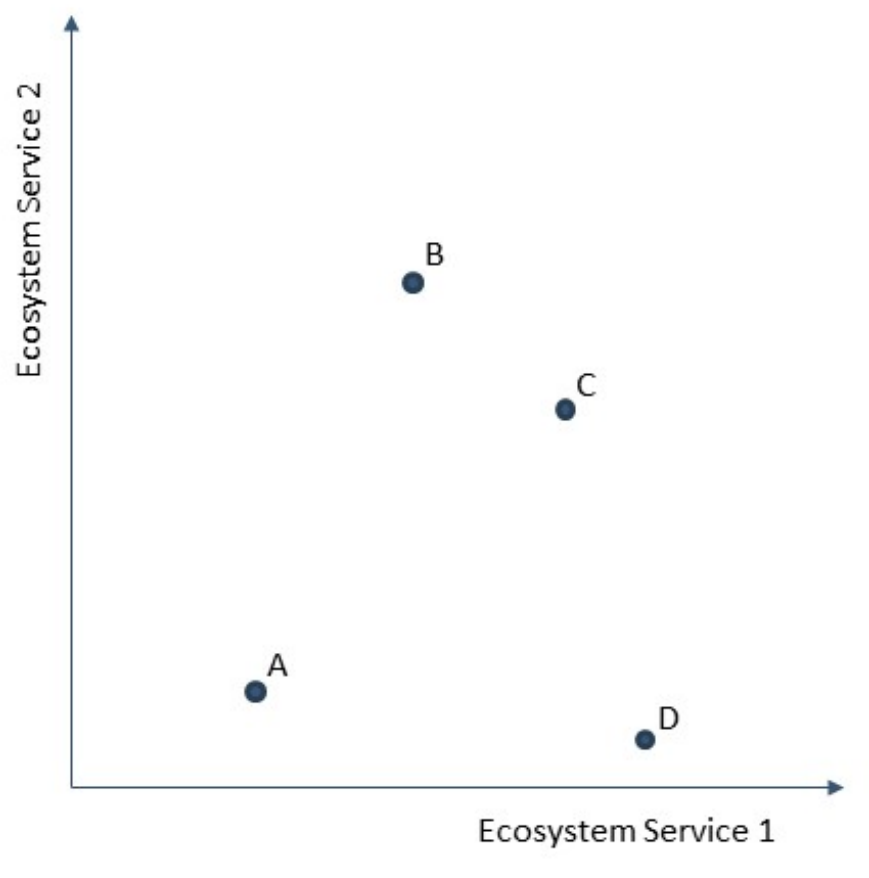

$\begin{array}{ll}\text { MENON ECONOMICS } & 24.04 .2017\end{array}$

Source: Based on Polasky et al. (2011); here reproduced from Magnussen et al. 2013.

It is easily seen that alternative $B$ and $C$ are preferred to $A$, because in $B$ and $C$ we can have more of both ecosystem services than in $A$. Choosing between $B, C$ or $D$ (or between $A$ and $D$ ) however, includes tradeoffs: Each alternative gives more of one ecosystem services and less of the other. If we were in situation $A$, in our illustration this would not make it necessary to make tradeoffs to choose alternative $B$ or $C$, since these alternatives give more of both services. Considering one set of management alternatives that gives the most efficient combination of the two ecosystem services, we can draw a line between these alternatives that define an "efficiency frontier" for the ecosystem services. These management alternatives are defined where it is not possible to achieve (produce) more of one service without reducing (producing less of) the other, that is why one has to make tradeoffs. 


\section{Tradeoffs over time}

Different management strategies can give benefits and costs that arise at different points in time. Two aspects are of particular relevance in this discussion:

- Discounting: How should we discount the value of a benefit or cost that arises in the future, so that all costs and benefits that accrue in the near or distant future can be compared? And of particular relevance for management of nature and ecosystem services: How can this best be done when the effects potentially will arise in a distant future?

- Real price adjustment: The value of goods and services can develop differently over time for many reasons. For example, there is reason to believe that some environmental goods and services may increase their relative value in the future, due to increased scarcity. Also, people's preferences may change over time, influencing the relative prices. This factor may work both ways for ecosystem services, and the values for some ecosystem services may increase relative to other prices (and indexes for such goods, such as the Consumer Price Index) due to scarcity and changes in preferences while others may not.

We will not discuss the issue of tradeoffs over time much further here, as they should be treated according to the guidelines for CBA the Nordic countries have developed (e.g. Kriström and Bonta Bergman. 2014), and which include guidelines for discount rates and real price adjustments. Also the need for real price adjustments are discussed in CBA guidelines in several countries, and the countries should check their own rules. This issue is first and foremost a case when using the ecosystem services framework in economic analysis where the value of ecosystem services over time is a question.

The issue is often less clear, also in CBA guidelines, for the so-called unpriced effects, for which ordinary discounting rules cannot be used. However, this is an issue beyond the scope of this report.

\section{Tradeoffs between interest groups}

Distributional effects can be analyzed and illustrated in many ways. The most advanced analyses use economic model tools to calculate how the effects are distributed in the economy for different groups. In many cases, less technical approaches in terms of rougher assessments of which main groups that are affected are justified.

It can be difficult to decide to what extent different groups are affected. An alternative framework can be to make a simple list of "winners" and "losers", as suggested for example in NOU (2012). Hein et al. (2006) suggest a way of showing distributional effects for local, county, national and global interests. 


\section{Spatial tradeoffs and relationship between production and use of ecosystem services}

A much-used illustration for spatial relations between the place where an ecosystem service is produced and where it is used or exploited is shown in Figure 2 below. The place of production is indicated with " $P$ " in the figure, while the place of ecosystem service use is indicated with "B" ("beneficiary"). The figure shows four possible spatial relationships. The first on top left in the figure indicates that a service is produced and used within the same, limited area. This will be the case where all the effects are local.

The other kind of relationship shows that the service is used by people outside the area in which the service is produced. The two last illustrations (bottom of the figure) show that the benefits of services are provided to individuals outside and in a particular geographic direction from the production area. Spatial relationships between producers and consumers (beneficiaries) areas (which is analogous to assess spatial distribution of costs and benefits in a cost-benefit analysis) is an important part of the understanding of tradeoffs or conflicts of interest. For example, it may be more difficult to solve a conflict where the costs of production of improved services are carried locally or by a particular economic sector while the benefits are harvested somewhere else or of other groups of people or sectors.

Figure 2: Possible spatial relationships between production and use of ecosystem services

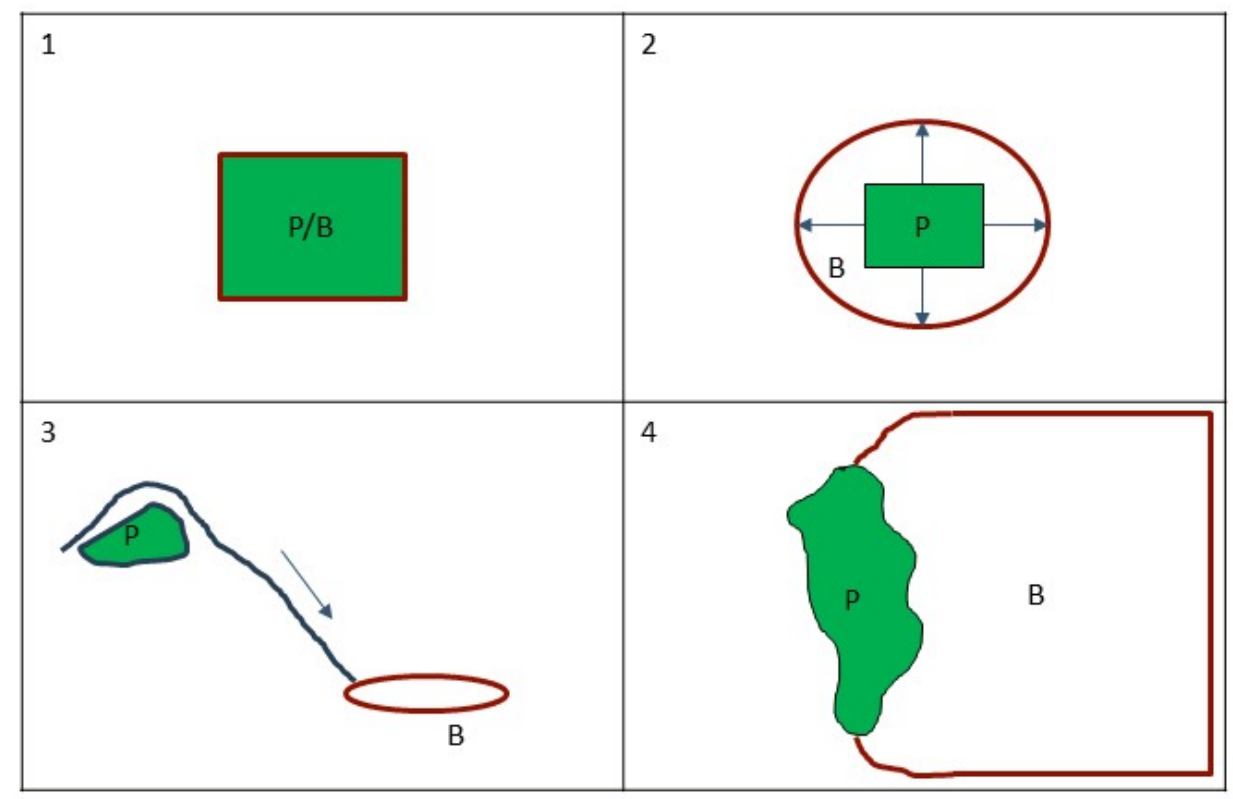

Source: Fisher et al. (2006). 


\section{Appendix 13. The Convention on Biological Diversity (CBD) and MSP}

Since the tenth Conference of the Parties (CoP10) to the Convention on Biological Diversity (CBD), held in Nagoya in 2010, the rapid loss of habitats and biodiversity has been highlighted also in Europe. The European Union has pledged to meet the targets formulated in Nagoya 2010 and a new and ambitious strategy to meet this challenge was formulated and adopted by the commission in 2011; EU Biodiversity Strategy to 2020 - towards implementation (COM 2011).

\section{The EU Biodiversity Strategy to 2020}

The EU Biodiversity strategy to 2020 (COM 2011) revolves around the 2050 vision declaring that:

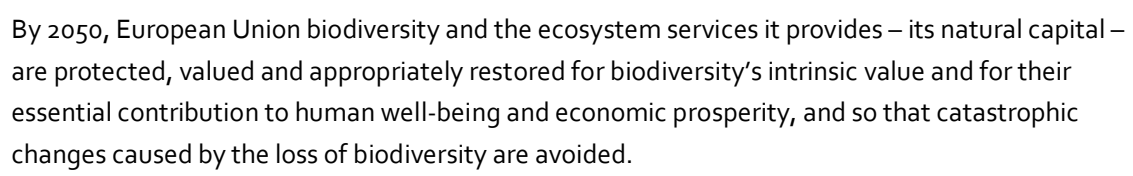

In 2011 , as a stepping stone to achieving the 2050 vision, the 27 member states adopted The EU Biodiversity Strategy to 2020. The strategy comprises six headline targets to be achieved by 2020 and its objectives are described as:

Halting the loss of biodiversity and the degradation of ecosystem services in the EU by 2020, and restoring them in so far as feasible, while stepping up the EU contribution to averting global biodiversity loss.

The six targets are:

- The full implementation of the EU nature legislation.

- Better protection and restoration of ecosystems and the services they provide, and greater use of green infrastructure.

- More sustainable agriculture and forestry.

- Better management of EU fish stocks and more sustainable fisheries.

- Tighter controls on Invasive Alien Species.

- A greater EU contribution to averting global biodiversity loss. 


\section{Links between the EU Biodiversity Strategy to 2020 (BDS2020)}

and MSP

A number of time related actions associated to each of the six targets have been developed in order to ascertain the fulfillment of the strategy. The targets and actions of the strategy shows very clearly that MSP has a significant role to play in the future work with fulfilling the objectives of the strategy.

The first target aiming at full implementation of the EU nature legislation primarily concerns the Habitats and Birds directives. A cornerstone in implementing these directives successfully is to uphold and manage favourable conservation status in the Nature 2000 network areas set aside for nature conservation purposes by the member states. This is considerable easier to achieve if the marine spatial planning in the member state seas stems from a common platform based on the notion of the ecological carrying capacity of the marine ecosystems and their services as being at the core of trade off processes.

The second target concerning better protection and restoration of ecosystems and the services they provide, and greater use of green infrastructure primarily aims at terrestrial habitats and environments. The concept of Green Infrastructure however is as significant in the marine environment as it is in terrestrial habitats. Article 10 of the Habitats directive (92/43/EEC) states that member states shall strive to improve the ecological coherence of the Natura 2000 network in applying spatial planning by managing the landscape features of specific importance for wild fauna and flora. The purpose being to facilitate migration, dispersal and genetic exchange of wild species. Although the directive doesn't discuss marine habitats specifically, annex 1 contains a list of marine habitats covered by the directive.

The fifth target concerns better management of EU fish stocks and more sustainable fisheries. Apart from combatting overfishing, the target also aims to ensure a more sustainable ecosystem based management of fisheries resources. This implies the protection of vulnerable marine ecosystems which will be dependent upon marine spatial planning as a crucial tool for implementation.

On a general level, increased collaboration between researchers and other stakeholders involved in spatial planning and land use management is identified by the EC as a "key partnership" in order to succeed in implementing biodiversity strategies at all levels.

The EU Biodiversity Strategy to 2020 also highlights the importance of ecosystem services as a tool to describe the social cost incurred to society if the loss of biodiversity is allowed to continue unchecked. The immense economic value represented by the ecosystem services, both to nature itself and to the society, shall be weighed against costs for taking actions to turn around the negative development. A set of indicators has been developed to assess the efficiency of the strategy. The assessment will be undertaken in 2020 and concerns e.g. assessments of improvement in ecosystem state and the services provided. 
Nordic Council of Ministers

Nordens Hus

Ved Stranden 18

DK-1061 Copenhagen K

www.norden.org

\section{Ecosystem services in MSP}

This study describes a proposal for a new tool on how to incorporate an ecosystem services approach into the maritime spatial planning process. The proposed tool provides a prototype for a stepwise methodology to analyze linkages between maritime activities and ecosystem services, and to assess the status of marine ecosystem services as a part of the MSP process. The report addresses the Nordic cooperation needs, economic valuation of ecosystem services and trade-offs between concurrent uses of marine areas and ecosystem services.

The study shows that making use of the proposed methodology enables and facilitates the incorporation of an ecosystem services approach in the planning process. However, in order to fully assess its possibilities, and the needs for further improvements, future work should focus on applying the methodology on a comprehensive marine spatial planning case. 